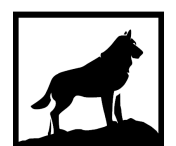

Michigan Technological

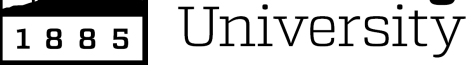

Michigan Technological University

Digital Commons @ Michigan Tech

\title{
LIVESTOCK-WILDLIFE DYNAMICS AND SUBSEQUENT HUMAN RESPONSES IN MARGINALIZED COMMUNITIES WITHIN MEXICO'S NATIONALLY PROTECTED AREAS
}

Deanna Seil

Michigan Technological University, dmseil@mtu.edu

Copyright 2020 Deanna Seil

\section{Recommended Citation}

Seil, Deanna, "LIVESTOCK-WILDLIFE DYNAMICS AND SUBSEQUENT HUMAN RESPONSES IN MARGINALIZED COMMUNITIES WITHIN MEXICO'S NATIONALLY PROTECTED AREAS", Open Access Master's Thesis, Michigan Technological University, 2020.

https://doi.org/10.37099/mtu.dc.etdr/975

Follow this and additional works at: https://digitalcommons.mtu.edu/etdr

Part of the Behavior and Ethology Commons, Biodiversity Commons, Community-Based Research Commons, Demography, Population, and Ecology Commons, and the Latin American Studies Commons 


\title{
LIVESTOCK-WILDLIFE DYNAMICS AND SUBSEQUENT HUMAN RESPONSES IN MARGINALIZED COMMUNITIES WITHIN MEXICO'S NATIONALLY PROTECTED AREAS
}

By

Deanna M. F. Seil

\begin{abstract}
A THESIS
Submitted in partial fulfillment of the requirements for the degree of MASTER OF SCIENCE

In Forestry
\end{abstract}

MICHIGAN TECHNOLOGICAL UNIVERSITY

2020

(C) 2020 Deanna M. F. Seil 
This thesis has been approved in partial fulfillment of the requirements for the Degree of MASTER OF SCIENCE in Forest Ecology and Management.

College of Forest Resources and Environmental Science

\author{
Thesis Co-Advisor: Audrey L. Mayer \\ Thesis Co-Advisor: Evan S. Kane \\ Committee Member: $\quad$ David J. Flaspohler \\ Committee Member: Kari B. Henquinet
}

College Dean: $\quad$ Andrew Storer 


\section{Table of Contents}

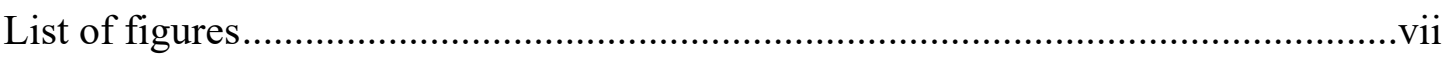

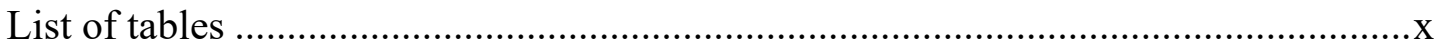

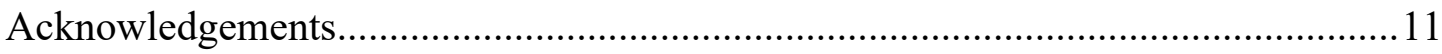

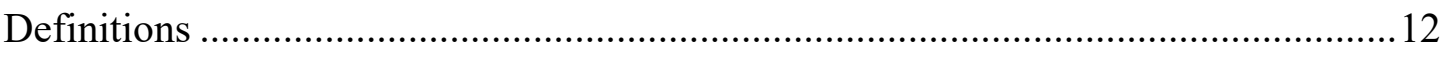

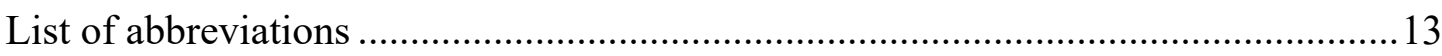

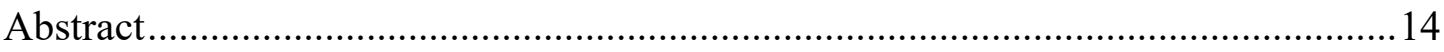

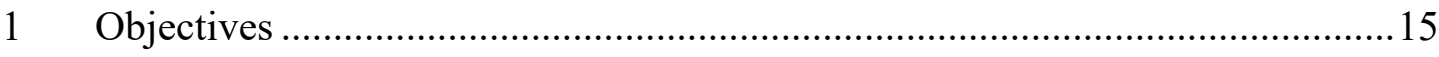

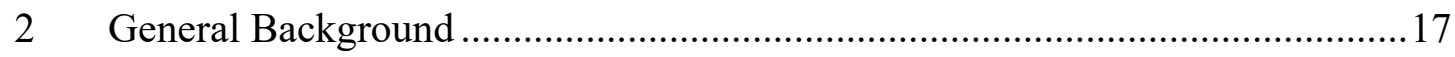

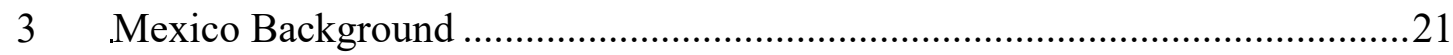

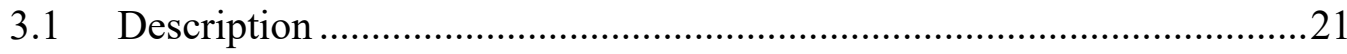

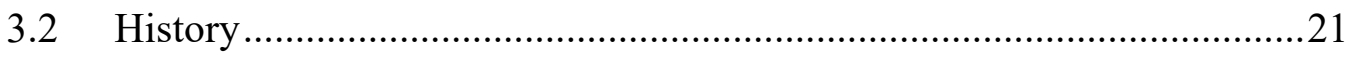

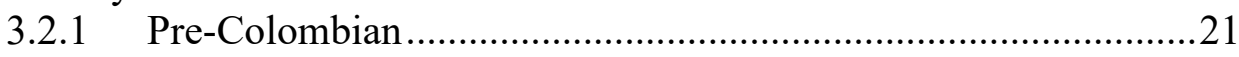

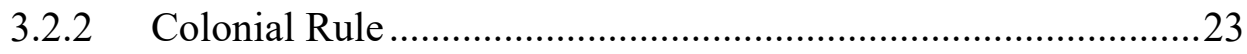

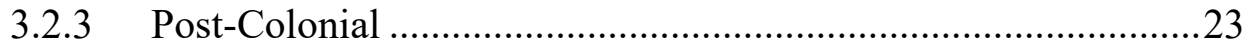

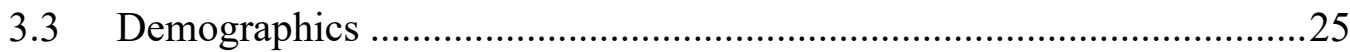

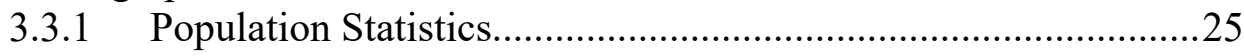

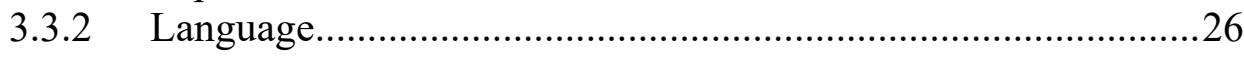

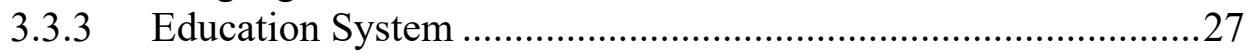

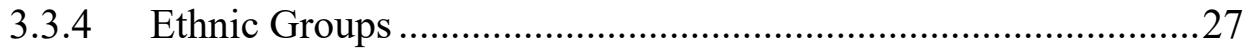

3.3.5 Religion and Religious Education ...........................................2

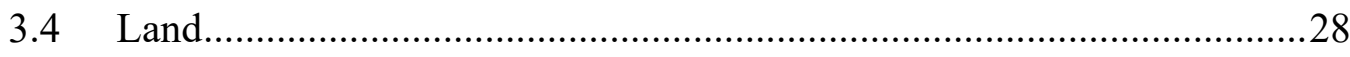

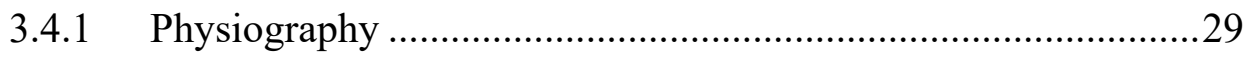

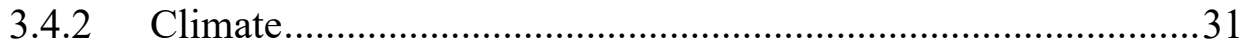

3.4.3 Biological Diversity...................................................................

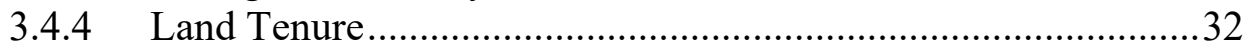

3.4.5 Land Protection Systems ...............................................................33

4 Tehuacán-Cuicatlán Biosphere Reserve Background ..........................................34

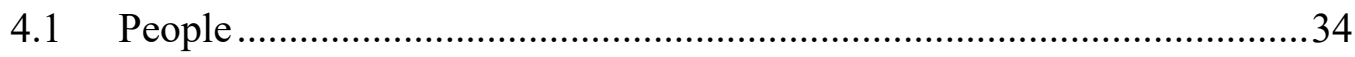

4.1.1 Population Statistics................................................................34

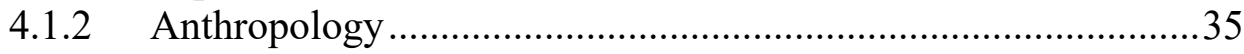




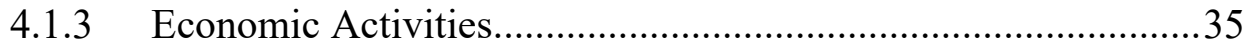

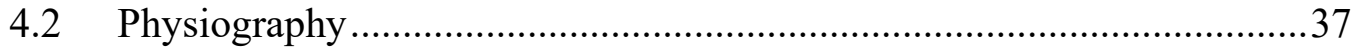

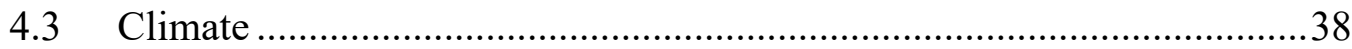

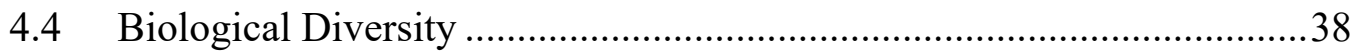

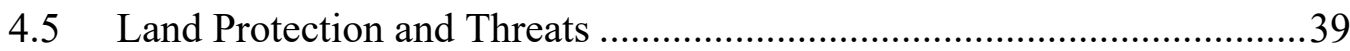

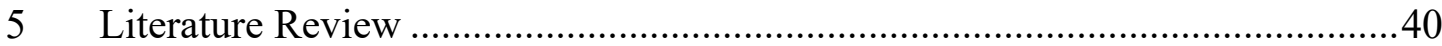

5.1 Impact of livestock on wildlife …………………................................40

5.2 Literature using camera traps for wildlife monitoring ...............................4

5.3 Ethnographic studies of HWC …………………...................................

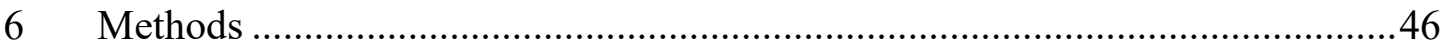

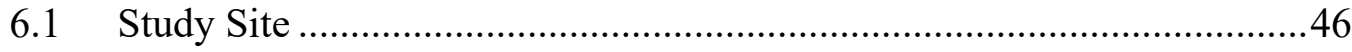

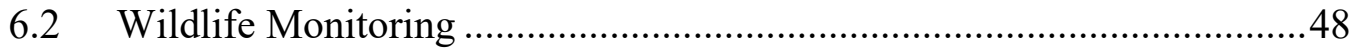

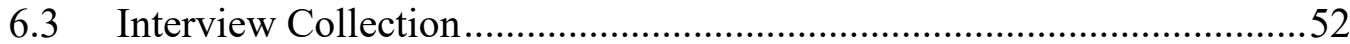

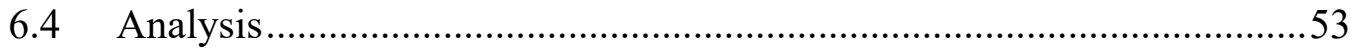

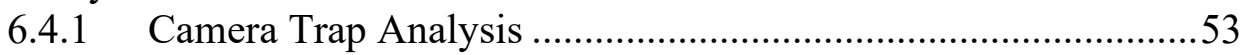

6.4.1.1 Data Organization.....................................................54

6.4.1.2 Species Data: Species Diversity and Richness ..........55

6.4.1.3 Detection/Non-Detection Data: Distribution, Occupancy and Abundance ........................................................56

6.4.1.4 Photographic Rate Data: Index of Activity ...............57

6.4.1.5 Activity Data: Kernel Density ....................................57

6.4.1.6 Ethological Data: Correlations ...................................57

6.4.2 Ethnographic Analysis............................................................57

6.4.2.1 Interview Analysis ....................................................57

6.4.2.2 General Ethnographic Observations ...........................58

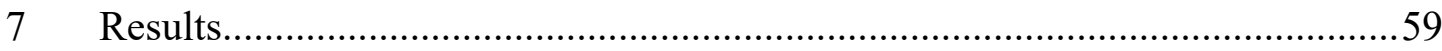

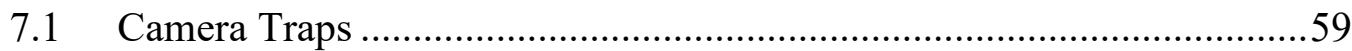

7.1.1 Species Diversity and Richness .................................................61

7.1.2 Detection/Non-Detection: Distribution, Occupancy and

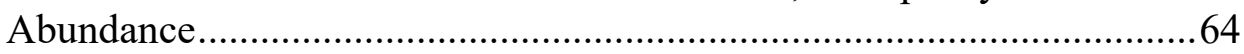

7.1.3 Photographic Rate Data: Index of Activity ...................................66

7.1.4 Activity Data: Kernel Density .......................................................68

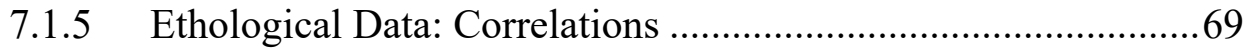

7.2 Ethnographic Results ......................................................................... 


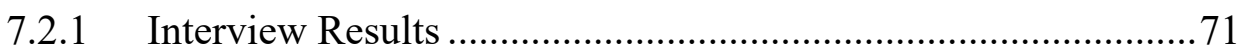

7.2.1.1 2017 Survey Results ..............................................71

7.2.1.2 Interview data from 2017 and $2019 \ldots \ldots \ldots \ldots \ldots \ldots \ldots \ldots \ldots . . . . .72$

7.2.1.3 2019 Survey Results ..................................................74

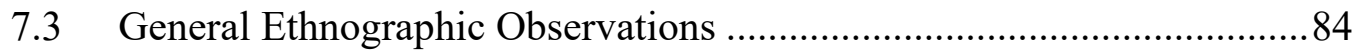

$8 \quad$ Discussion.................................................................................................. 93

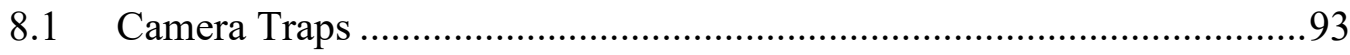

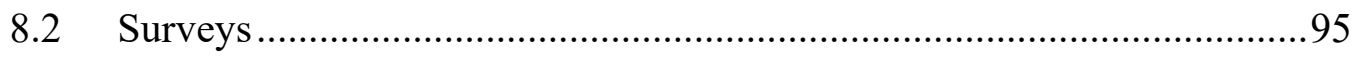

8.3 Ethnographic Conclusions ………………………..............................97

8.4 Other Factors to Consider .......................................................................98

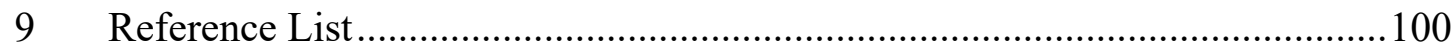

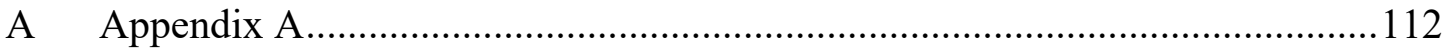

A.1 Institutional Review Board Project Submission ……………………......112

A.2 2019 Interview Questionnaire ............................................................114

A.2.1 English Version ....................................................................114

A.2.2 Spanish Version ........................................................................117

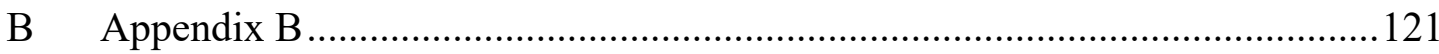

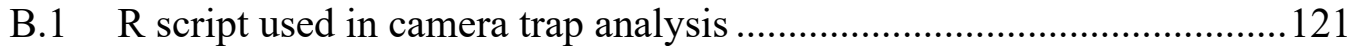

B.1.1 Shannon Wiener and Rényi Code..........................................121

B.1.2 Species Accumulation Curve.................................................121

B.1.3 Correlation code..................................................................121

B.1.4 Chi-squared Code .................................................................... 121

B.1.5 Scatter Plot of Pearson's Correlation........................................122

B.1.6 Kernel Density Estimation........................................................122

B.2 R script used in ethnographic analysis ...............................................122

B.2.1 Simple bar graph................................................................122

B.2.2 Box whisper plot................................................................ 122

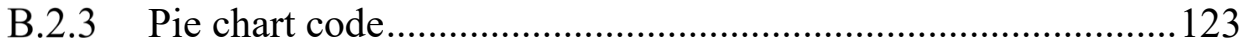

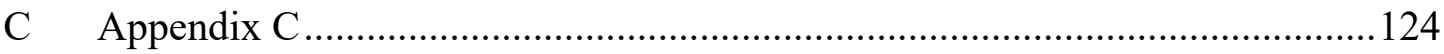

C.1 Field Sheet for Biodiversity Monitoring …………………….................124

C.2 Camera Trap Data Sheet ..................................................................... 128 


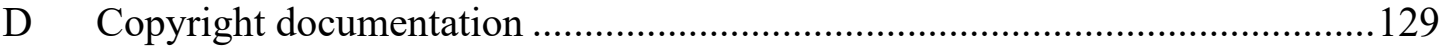




\section{List of figures}

Figure 2.1: What kept me in Mexico (photo by the author).

17

Figure 2.2: Biologist Leticia Soriano Flores - a crucial figure in my Peace Corps

experience (Photo by the author).

Figure 3.1: Figure of population age structure in Mexico (2018) (Central Intelligence

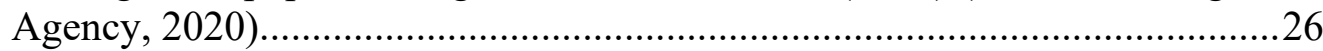

Figure 3.2: Catholicism is a key element of Mexican society (photo by the author)..28

Figure 3.3: Tectonic plates in Mexico. Remarkably, it is the North American Plate's interaction with the Cocos Plate that has caused the major earthquakes in the last century (Figure by Tony Burton/Geo-Mexico, https://geomexico.com/?p=6277).

Figure 3.4: Map of 11 physiographic regions of Mexico (Alcocer \& Bernal-Brooks, 2010)

Figure 4.1: Tehuacán-Cuicatlán Biosphere Reserve (map by author)........................ 34

Figure 4.2: Fossils in the RBTC - Santiago Coatepec (photo by the author)..............38

Figure 6.1: Study site during the wet season (photo by the author). ........................46

Figure 6.2: Caltepec Bienes Comunales during camera trap monitoring (photo by the author) 48

Figure 6.3: map of the study area (map made by the author) .................................50

Figure 6.4: Interview collection (photo by Benita Luna - PCMX training director)...52

Figure 6.5: learning from a UNAM professor and founder of CONBIODES to design a camera trap study. (Photo courtesy of the author.) ..................................54

Figure 6.6: Folder system in ADATA 1T hard drive (figure by the author) ...............55

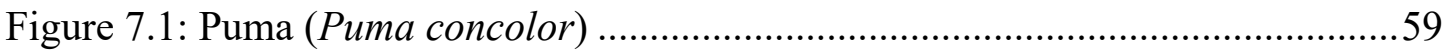

Figure 7.2: Rényi diversities for six randomly selected sites. The hollow blue dots represent the site numbers and the dashed lines represent the maximum, median and minimum values across the randomly selected sites. The $\mathrm{x}$-axis represents the likelihood (alpha) that the sample size is within the true 
population size as alpha moves from zero to infinity. Overall, the graphs with higher lines have higher biodiversity ..................................................................63

Figure 7.3: Accumulation curve of species over number of sites..................................64

Figure 7.4: Species detection during dry season visits camera visits..........................65

Figure 7.5: Species detection over wet season camera visits. .....................................65

Figure 7.6: Wild versus domestic animal observations at each camera station per 100

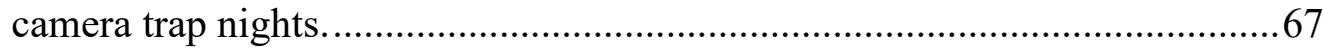

Figure 7.7: Habitat preference between wildlife and livestock. Photographic activity (number of triggers per sampling effort standardized over 100 days) is seen to be different between habitat type and species type. ..........................................67

Figure 7.8: Densities of wildlife activity over a 24-hour period. ..................................68

Figure 7.9: Densities of livestock activity over a 24-hour period. ................................69

Figure 7.10: Donkeys driving off coyote (camera trap photo) .....................................69

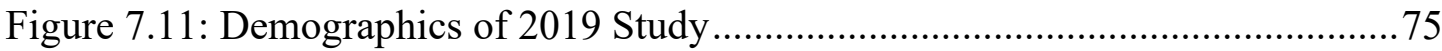

Figure 7.12: Domestic animals per household in Coatepec 2019................................77

Figure 7.13: Number of community members who have animals on communal land.

Figure 7.14: Perceived threat of animals in Coatepec................................................79

Figure 7.15: Showing the wildlife that community members valued...........................79

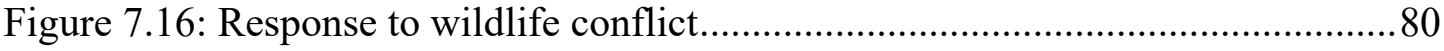

Figure 7.17: Perceived importance and impact of biological monitoring. ....................83

Figure 7.18: A diagram of factors influencing the perceptions about biodiversity in

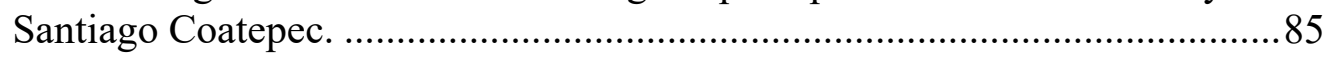

Figure 7.19: Mezcal and dragon fruit production are the main livelihoods of people in

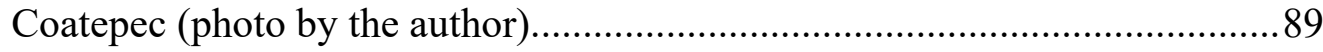

Figure 7.20: Community members showing off their photos for the presidential area. 
Figure 8.1: Community members René Balderas and Diana Lezama Luna at an environmental education event in the municipality (photo by the author)......97 


\section{List of tables}

Table 6.1: Table of camera trap stations and covariate information (table by the author).

Table 7.1: Camera results showing total captures, trapping success and independent

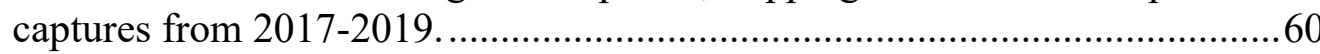

Table 7.2: Shannon-Wiener Index by site (Rstudio results)........................................61

Table 7.3: Observed behaviors of livestock and wildlife. ............................................70

Table 7.4: Summary of data collected in CONBIODES group interview in 2017

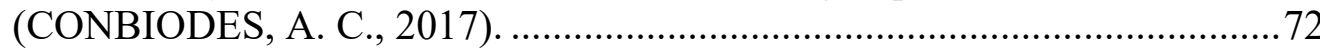

Table 7.5: Domestic animals reported in the 2017 group survey and the 2019 survey.

Table 7.6: 2017 and 2019 survey results of livestock loss and feral dog presence in Santiago Coatepec. .74

Table 7.7: 2019 Survey Demographics ..................................................................... 75

Table 7.8: Table of recorded responses to wildlife conflict. .........................................8 80

Table 7.9: Desired programs for wildlife conflict mitigation....................................... 81

Table 7.10: Perceived impact of biological monitoring ............................................... 82

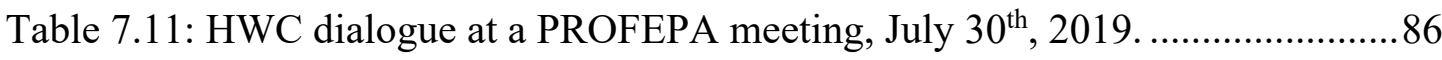

Table 7.12: Measures taken to mitigate human-wildlife conflict in Santiago Coatepec. 


\section{Acknowledgements}

First and foremost, I would like to express the deepest of gratitude towards my advisor, Dr. Audrey L. Mayer, for her enduring patience, support and guidance throughout the entirety of Michigan Technological University's Peace Corps Master's International (PCMI) Program. Similarly, I sincerely appreciate the effort by my entire thesis committee, including co-advisor Dr. Evan S. Kane, Dr. Kari B. Henquinet, David J. Flaspohler and other individuals in the Michigan Technological University community, such as Dr. Kristin Brzeski, Dr. Jared Wolfe, Dr. Blaire Orr, Rhiley Allbee, all of whom have helped me work through many thought problems during this process.

I am especially indebted to the community members and host country counterparts living and working within the Tehuacan-Cuicatlan Biosphere Reserve; for the hundreds of hours they spent with me, and all that they taught me over two years. Thank you to the Reserve Director Fernando Reyes-Flores, for always supporting my ideas and helping to implement many projects over the two years. Also, to Leticia Soriano Flores, as my main counterpart for her enthusiasm and heart she poured into her work and mine. Thanks also to Socorro Garcia Mendez, for opening your home and heart for me and supporting me through all of the tasks. Thanks to Beatriz Beristain Noriega, for pushing me to participate in regional talks and conferences and ensuring a high standard of work quality. Thanks also to Maria Luisa Hernandez Aguilar, Adrian Sotelo, Zayareth Belendez Hernandez, Wilmer Salazar for supporting me through various workshops and activities related to my study objectives. Thank you to all of the community members in Coatepec who opened their hearts and homes to me, particularly the Ejido and Bienes Comunales leaders such as Don Silviano Correa Rodriguez, and Don Berto Salazar Geraldo, to the conservation committee who spent countless hours working with me on many projects, principally Rene Serrano Balderas, Diana Lezama Luna and Carlos Luna. To my host families for always supporting me through the process, especially Doña Carmen Salazar, Nayeli Noguez and Yazmin Gerardo.

Thanks also to Peace Corps Mexico, for the direction and confidence they imparted to work in a culturally appropriate and effective manner, especially Country Director Jean Seigle, Safety and Security Director Magdelena Vazquez, Environmental Track Managers Angel Pineda and Benita Luna, Small Grants Coordinator Maria Martinez, Language and Culture Coordinator Laura Mendez and Dr. Irma Melgar.

Finally, thank you to my family and friends at home. To Donald, Lisbeth, Kristina and Shannon Seil for instilling in me a sense of ambitious curiosity from a young age - you are the real inspiration behind my life pursuits. For Peter Meingast and Jessica Daignault for packing me lunches and bringing me dinner when I didn't have time to do it for myself.

None of this would have been possible without each and every one of you. 


\section{Definitions}

Nucleo Agrario - General term to describe communal lands (forests, lands, water) in Mexico endowed by the President or agrarian courts.

Bienes Comunales - Communal land management type in Mexico - formed during agrarian reform in 1971.

Ejido/al - Communal land management type in Mexico - formed during agrarian reform in 1971.

Fondo Legal - Urban communal land management type in Mexico.

Comisariado - Leader of the communally-owned land in Mexico.

Malinchismo - derogatory term meaning preferential treatment of foreigners and betrayal of fellow citizens (inferiority complex). It comes from the name of the enslaved woman, La Malinche, who helped Hernán Cortéz understand the Nahuatl language and Mexican culture when he arrived in the 1500's.

Bachillerato - Type of high school in Mexico that is more alike to trade school and prepares students to work.

Preparatoria - Type of high school in Mexico that prepares students to continue studying at a university.

Secundaria - Middle School in Mexico.

Assemblea - Assembly; communal lands mechanism for various functions such as making decisions and holding members accountable. During an "assemblea" all members of that particular land type should be present. 


\section{List of abbreviations}

PCMI - Peace Corps Masters International

PCMX - Peace Corps Mexico

PCV - Peace Corps Volunteer

NRC - Natural Resource Conservation

MTU - Michigan Technological University

RBTC - Tehuacán-Cuicatlán Biosphere Reserve

ANP - Nationally Protected Area

SEMARNAT - Secretary of the Environment and Natural Resources

CONAGUA - National Water Commission

CONANP - National Commission of Natural Protected Areas

CONAFOR - National Forestry Commission

CONABIO - National Commission for the Knowledge and Use of Biodiversity

IMTA - Mexican Institute of Water Technology

PROFEPA - Federal Attorney for Environmental Protection

INECC - National Institute in Ecology and Climate Change

ASEA - Agency for Security, Energy and Environment

SADER - Secretary of Agriculture and Rural Development

CONBIODES - Conservation Biology and Social Development

PROCODES - Program for Conservation for Sustainable Development

UNESCO - United Nations Educational, Scientific and Cultural Organization

INALI - The National Institute of Indigenous Languages

NAFTA - Mexico ratified the North American Free Trade Agreement

EBA - Endemic Bird Area EBA

IUCN - International Union for Conservation of Nature

NGO - Nongovernmental Organization

SCR - Spatial Capture-Recapture

GLM - General Linear Model

HWC - Human Wildlife Conflict 


\section{Abstract}

Entering the planet's sixth mass-extinction, monitoring biodiversity and the factors which affect it is of the utmost importance. This study on the interaction of humans and their livestock with wildlife, and the impact of this interaction on wildlife conservation, took place in Santiago Coatepec, located within the Tehuacán-Cuicatlán Biosphere Reserve in Mexico. Wildlife interactions with livestock may depend upon species, season, ecological characteristics of the area, and livestock management practices. Using camera traps, field data, and interview data, I quantified livestock impact on wildlife behavior and community beliefs. Over two years, camera traps at 18 stations recorded 709 wildlife videos and 2360 livestock videos. I collected 29 community questionnaires, clarifying management practices and environmental beliefs. Livestock was recorded most often in communal farmlands (968 videos) and near streambeds (1002 videos), while wildlife was concentrated in rugged terrain (258 videos) and hillsides (171 videos). The greatest wildlife diversity was seen in rugged terrain (12 species) and farmland/river (10 species). Wildlife triggers dropped during the wet season, while livestock triggers remained constant year-round. $71 \%$ of recorded livestock-wildlife interactions were negative (17 of 24). Community interviews ranked biodiversity monitoring as very important (19) or important (10). 47\% of participants reported pumas/coyotes as dangers to the community, while $68 \%$ believed white-tailed deer were the area's most valued wildlife species. Camera trap data demonstrated that wildlife and livestock interactions were predominantly negative. Community members valued wildlife but feared livestock losses due to depredation by wildlife and diseases from wildlife. Recognizing the dramatic effects of livestock on wildlife and how these interactions impact local value of wildlife is crucial to long-term mitigation strategies -which must offer a greater understanding of community vulnerabilities, perceptions and address social factors in order for the survival of native species in the biosphere reserve and globally. 


\section{Objectives}

As we enter the planet's sixth mass-extinction event, monitoring biodiversity becomes critically important. Humankind depends upon biodiversity for food, medicine, primary materials, clean air, water, carbon storage, soil formation, storm protection, mental health services and many other remarkable functions (Millennium Ecosystem Assessment, 2005) With the looming effects of climate change and human-caused habitat loss, it is of extreme importance to monitor in situ biodiversity and subsequent threats.

The Tehuacán-Cuicatlán Biosphere Reserve, located in Southeastern Mexico, is the most biodiverse high desert ecosystem in the world. In 2018, the reserve was named a World Heritage "Mixed" Site partially for this incredibly rich biological endemism, as well as its cultural importance (Centre, 2018). The Tehuacán Valley has been called the "birthplace" of modern agriculture; the first evidence of cultivated corn, avocados, chilies, beans and squash were unearthed in caves that dot the edges of the valley.

Over the past few thousand years, the human-nature relationship has been pivotal in shaping and maintaining the biodiversity of this region. Modern times, however, have brought new threats to the reserve's biological stability. Livestock introduction, the industrialization of extractive activities, infrastructure development, biological market demand increases (rare cacti, cactus fruits, fibers, rare wildlife pets) and increased tourism have caused rapid alterations to the area.

Of the 490,186 hectares of land within the reserve, most are communally owned - a consequence of land redistribution and reform during the 20 $0^{\text {th }}$ century (Assies, 2008; UNESCO, 2018). Details of the region's flora and fauna are still unknown, and the local human communities are an integral aspect of further research and conservation. Community monitoring efforts have led to biodiversity findings that are crucial to future conservation objectives. From 2017-2019, communities noted ten new bat species, verified jaguar presence in the area, identified a new cactus species (which was then described and published), recognized new Hectia and Agave species, and identified the southernmost golden eagle nest on the continent (Centre, 2018; Davis et al, 2018; Martorell et al., 2017).

From 2017-2019, I collaborated with the Biosphere Reserve personnel to develop community-driven biodiversity monitoring, engage communities in environmental education and implement sustainability projects. My research examined the success of community monitoring program adoption and subsequent behavior change to minimize human-wildlife conflict. In Santiago Coatepec, Puebla, communal land was used to graze free-range goats, sheep, cattle, horses, mules and donkeys. I wanted to see if and how animal husbandry affected wildlife populations. The Reserve personnel were also 
curious as to the impact grazing had and how communities reacted to their efforts of biological conservation and environmental education.

Human-wildlife conflict is occurring with increasing frequency around the world, as burgeoning human populations expand into previously uninhabited areas (Dickman, 2010). I investigated the underlying conditions that might affect perceptions of HWC in Santiago Coatepec. This was a community where humans were dependent on, and had cohabitated with, nature for hundreds of years. I wondered if community members perceived wildlife to be less of a threat to them, if two-years of environmental education could shift inherited beliefs towards wildlife, and if, despite living in a protected area, people would react proportionately or disproportionately to damages by wildlife if they occurred (if a puma killed a goat would they then go kill they puma). All of this would matter in reaching my research objectives. Human-wildlife conflict scenarios are rarely simple and require an interdisciplinary assessment. Luckily for me, I had two years to spend assessing these biological and ethnological questions in the hopes of preparing a well-rounded investigation into the topic. I hope that my work can be applied to developing mitigation strategies to human-wildlife conflict and to enable betterinformed livestock management decisions in biologically and culturally important areas. 


\section{General Background}

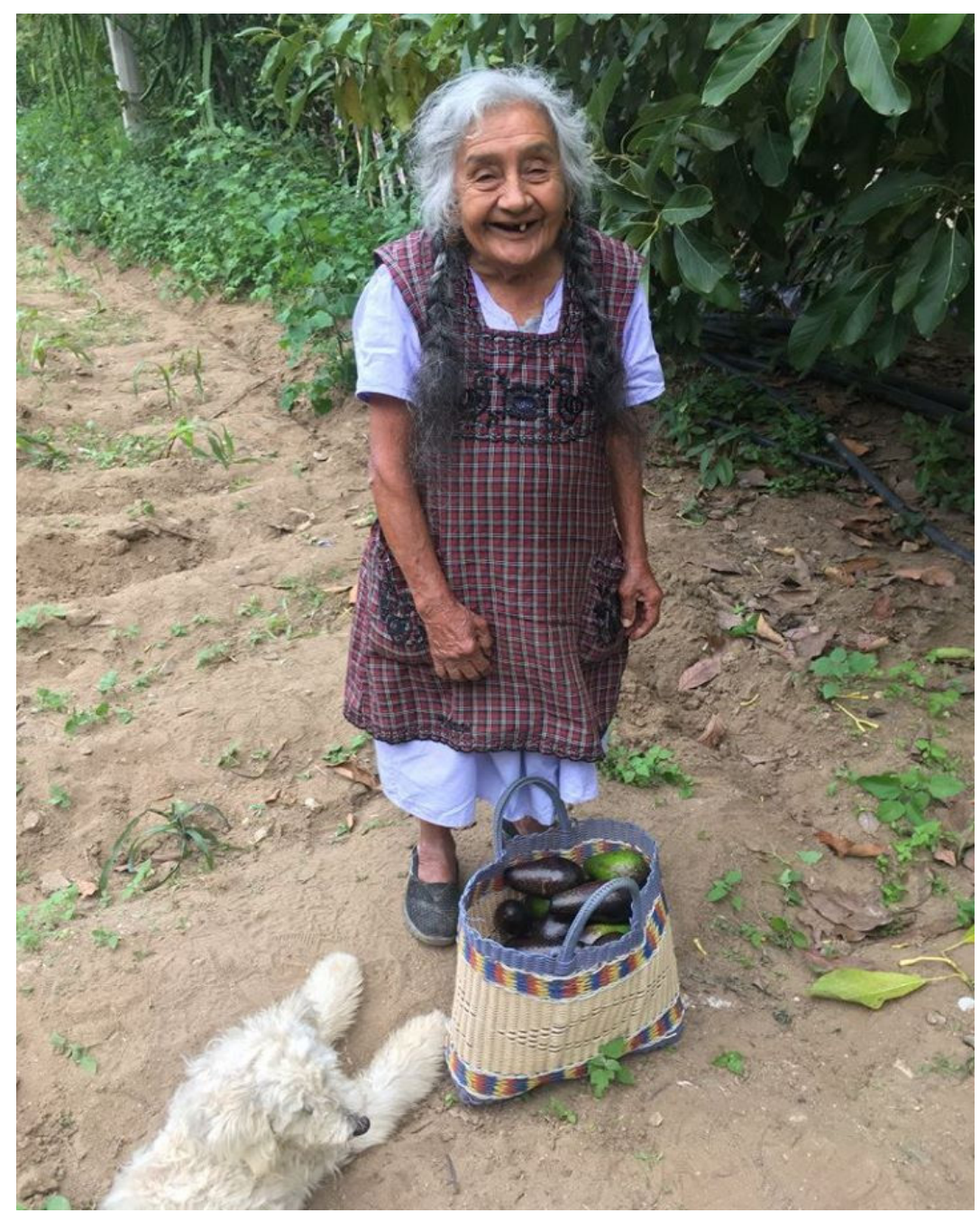

Figure 2.1: What kept me in Mexico (photo by the author).

In 2016, I became part of the last cohort of Peace Corps Master's International (PCMI) students at Michigan Technological University (MTU) in the College of Forest Resources and Environmental Sciences. I served as a Peace Corps Mexico Volunteer (PCMX) as part of their environment program from June 2017 to August 2019. Under Mexico's Secretary of the Environment and Natural Resources (SEMARNAT), I was assigned as a Natural Resource Conservation Volunteer (NRC) to the TehuacánCuicatlán Biosphere Reserve (RBTC), part of the Commission of Nationally Protected Areas (CONANP) system. My primary responsibilities were to enact community driven biological monitoring, facilitate environmental education initiatives, and develop local sustainability projects. 
No words can succinctly sum up my experience as a Peace Corps volunteer. As a whole, I feel I had a largely successful service and was able to accomplish much more than expected - including incorporating Master of Science research in the process. However, there were so many setbacks and hindrances along the way, bringing me almost to the point of giving up and returning home. I knew going into the Peace Corps I would come out a different person, I just did not know how drastically this experience would etch itself into my soul. I believed I would be working on a soil and water conservation project but ended up working on wildlife monitoring - I had never even taken a wildlife biology class in school. Peace Corps service doesn't care about what you have or have not had experience in, it cares about what you are willing to learn and do in order to fulfill the needs of your community - I find this to be a fairly good metaphor for life.

I discovered I was going to serve in Peace Corps Mexico on the day of the 2016 election. It felt especially important to commit to becoming a positive representative of the United States as international tensions were at an all-time high. Six months later, I stepped off of the plane full of the nervous energy that any big life change brings. I was immediately swept up in the sounds, colors and scents that fill the Mexico I experienced. Over the next few months, the other new Peace Corps trainees and I developed and practiced skills while learning about our surroundings. On August 24th, 2017, 31 trainees dedicated themselves to fulfill the goals of a Peace Corps Mexico service.

I vividly remember the journey to my site. After an eight-hour bus ride, I asked around at the local bus station for a taxi that might know the way to my community. The "taxistas" talked amongst themselves and a few minutes later a man stepped forward claiming he knew where to go. I had a screenshot of a map on my phone and we headed out into the night. Two hours into the bumpy taxi ride, I grew nervous as we made hard decisions regarding where to turn. We came to one fork in the road and decided to turn right. As we winded down the mountain road, we came across the communal land leaders of my community! They told me we were going the wrong way but pointed us in the right direction and asked me if I would like to come to training with them at 6:30 the next day. As I had seen them at night, I believed that they had meant 6:30 pm and was surprised to be awoken before sunrise by someone knocking loudly on my door. During that training, photos were taken of me in my pajama shirt that would be used in the creation of a series of posters which were then printed and used around the whole reserve. This was how my Peace Corps service began.

Mexico is a wild and vibrant place. Over the two years, I ultimately grew almost fond of constant banda music played at all hours, the menudo (organ soup) for breakfast and the vaquero (cowboy) culture. There were times I felt were especially meaningful planting corn and harvesting avocados with my 83-year-old host grandmother - and others leaving me repulsed, afraid, isolated, angry; I experienced the full breadth of human emotion during these two years (Figure 2.1). 


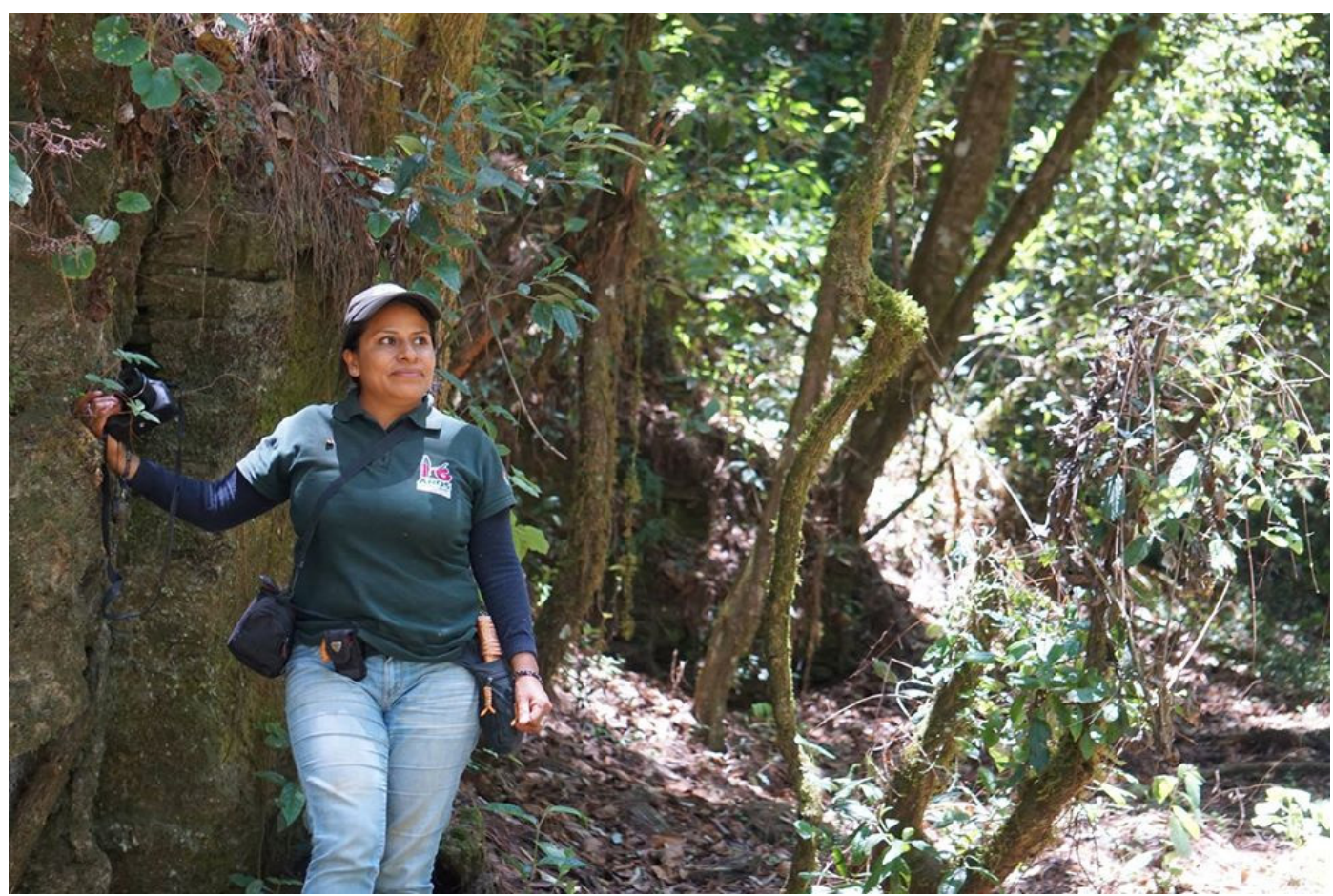

Figure 2.2: Biologist Leticia Soriano Flores - a crucial figure in my Peace Corps experience (Photo by the author).

My host country counterpart, Leticia Soriano Flores, showed me what was necessary to be a respected woman within the field of natural resource management in a patriarchal system (Figure 2.2). Under her guidance, I developed and refined the tools to succeed within the Mexican Nationally Protected Area (ANP) context. The conservation initiatives enacted in my community during my two years as a Peace Corps Volunteer were largely due to her influence as well as the community's desires to know about their land. With her support, I worked with fourteen communities within the reserve: San Luis Atolotitlan, San Simon, Caltepec, Acatepec, Zapotitlan Salinas, Santiago Dominguillo, Cuicatlan, Tilapa, Santa Maria Papalo, Aztatla, Tepelmeme, Coixlahuaca, Necactepec, and Santiago Coatepec. I facilitated twenty-three classroombased and field-based training sessions, participated in over sixty field monitoring events, and compiled reserve-wide data on camera traps - results later presented in an International Symposium on Neotropical Felines. While these numbers may seem impressive, there were so many moments of frustration and mistakes. One communal group abandoned the project halfway through, saying it was a waste of their time, and asking me why I didn't just teach English. Even after being at site for almost two years, I still would receive questions about what I was doing there, how long I had been visiting for, or if I was a spy. 
I remember that during the first week, a family invited me over for dinner and the son told me about how his father had once hunted and killed a cougar for attacking his animals. Soon after, during camera trap monitoring, the comisariados (town leaders) found a goat carcass and blamed the attack on a puma, even though the tracks around the animal were clearly left by dogs and the way the animal was killed did not match the way cats generally attack. The man who lost the goat explained that it was a coyote that had made the kill and that his dogs had eaten the rest of the carcass. Word drifted around that the comisariados planned to put together a party of men to kill the coyote responsible for attacking the goats. This made me begin to question what our biological monitoring was achieving. People were so excited to see deer on the camera traps, but was monitoring just allowing them to see what was available to hunt or to assess the threats to their livestock? How did livestock compete with native species here? Could camera traps provide evidence? Would two years of environmental education alter the mindsets of community members such that their automatic response wasn't to just shoot or kill whatever wild animal they came across? These were the thoughts that began to cross my mind as I trekked the hills and valleys around the RBTC. 


\section{Mexico Background}

\subsection{Description}

Thought to mean "Place at the navel of the moon" in Nahuatl, the United States of Mexico is the fifth largest country in the Americas and shares borders with three neighboring countries - the United States to the north, and Guatemala and Belize to the

south. Its western and eastern borders are lined by the Pacific Ocean, the Gulf of Mexico and Caribbean Sea (Parkes, 2020). Not unlike the United States, Mexico's 770,000 square miles is broken up into 31 states. Mexico is also naturally divided by its diverse physiographic regions. It is considered one of the Earth's most megadiverse countries, supporting the second largest number of ecosystems and containing roughly 10-12 of the Earth's species (Biodiversity in Mexico, 2015). Perhaps from this physiographic diversity stems its rich cultural unfolding, with its many native languages, food, music and unique traditions.

\subsection{History}

Crucial to understanding the context in which the research of this thesis took place is the complex history that has shaped present day Mexico. The land tenure regimes, the mixture of pagan and Christian religions which dictate daily rituals, the legacy of the Aztecs - both linguistically and socio-politically, the foundations for "malinchismo," and the reverence-fear relationship Mexico has with nature - all in some way shaped the culmination of this project.

\subsubsection{Pre-Colombian}

Mexico is one of the world's six "cradles of civilization." The first inhabitants of the Americas arrived during the later period of the Pleistocene Epoch (30,000-40,000 years ago), although their descent into Mexico remains debated (Parkes, 2020). The first evidence of human artifacts date to around 9000 BC. From 9000 BC to the 1500's, Mesoamerica would develop systems of agriculture, two different calendars, a number system, pictographic writing systems and complex physical structures such as stepped pyramids.

With the retreat of the glaciers, humans during this time adapted their livelihoods from pursuing large land mammals to more localized hunting and gathering (El Riego period). During the Early Formative time, these peoples created more permanent settlements and began to hybridize and cultivate wild plants (Mangelsdorf, 1964). In the Tehuacan Valley, the first examples of cultivated avocados, chilies, beans, corn and 
squash have been dated as early as 5,000 BC. Dwellings developed from caves, pithouses, and pottery have been dated circa 2,300 BC.

In the Middle Formative Period, complex societies emerged centered around religiouspolitical centers (Parkes, 2020). At this time, these densely populated settlements were wholly dependent upon agriculture. Examples of large stone sculptures by Olmec artists, such as altars, mosaic masks, stone heads, and stelae, were found in Veracruz and Tabasco. These artists often depicted humans with jaguar-like features (head, mouths) throughout their artwork.

Complex societies throughout Mexico began to emerge in the Late Formative Period. This was when the true city center arose, such as Teotihuacan (now a popular tourist destination), which supported 150,000 to 200,000 inhabitants in roughly 8 square miles. This period is also known for the astrological and mathematical contributions of the Maya, which led to perhaps the most accurate calendar system in the world.

Though archeologists are not certain of the cause, the classical world seemed to falter, and a new period of history began. Judging by the war-filled artwork, militant societies seemed to take the place of the classic period's relatively peaceful civilizations. This period marked the rise of the Aztecs with the fall of the impressive Tula and Toltec cultures.

The word Azteca comes from a Nahuatl word meaning "Land of White Herons," in reference to their origin in northwestern Mexico (History.com, 2020). Nahuatl is part of a linguistic family Uto-Aztecan that stretched as far north as now Wyoming and as far south as Panama (Campbell, Kaufman, \& Smith-Stark 1986). Legend claims that the Aztec sun god Huitzilopochtli told them to search for a home where a golden eagle was found eating a snake on a nopal (cactus). This led them on a pilgrimage lasting a century (12th-13th), ending when at last they saw the vision their god had referenced only it came on a small island in the middle of a lake.

This small wandering tribe ended up in an almost uninhabitable swamp, but due to its strategic location, economically and to other societies, combined with the tribe's religion and political organization, the Aztec people would build an empire within a century akin to few other civilizations throughout human history.

The swamp that other powers had avoided became a main source of the Aztecan success. The channels provided expansive passageways between lake systems allowing for fast transport of goods before pack animals had been domesticated. The floating islands in the lake and mild climate enabled the resources and conditions necessary for intensive agriculture production. Their religion suggested that they had to continually give human sacrifices to the sun god Huitzilopochtli, so war and subsequent conquest was an obligation. Their political organization was complex, with 
many aspects still in debate. What is clear is that they would subjugate their allies and collect taxes regionally to expand their empire even further.

\subsubsection{Colonial Rule}

The Spanish explorer Hernán Cortés arrived by ship in 1518 AD in a place he named Veracruz, or "The Real Cross." Several factors led to the defeat of the Aztecs by the roughly 500 men in Cortés's expedition (Parkes, 2020). Word came to the ruling monarch, Montezuma, that boats bigger than houses had arrived on the coast and led him to suspect that these were indeed returning gods. Cortés gained allies with many of the conquered groups living under the Aztec rule, and, with the help of la Malinche, his servant-translator-mistress, Cortés was able to better understand the culture and language. These Spaniards also brought with them a host of weapons - muskets, steel, swords, crossbows, dogs, and horses - but also deadly germs. It has been estimated that European diseases ("cocoliztli") killed roughly 12-25 million native Mexicans during the Spanish conquest (Acuna-Soto, Stahle, Cleaveland, \& Therrell, 2002). After the Spanish brutally murdered Montezuma and thwarted pushback by the last two Aztec Emperors, the Spanish proceeded to rebuild the smoldering ruins of the main city, Tenochtitlán, by immediately constructing a Catholic cathedral on top of the Huitzilopochtli temple - using its very stones to do so.

The Spanish conquest happened quickly across Mexico, with hindrances only in the Yucatan peninsula and sparsely populated northern Mexico. Expansion northward was motivated by the threat of other European powers. The northern boundary of Mexico remained in dispute until the Adams-Onís Treaty of 1819 between the United States and "New Spain". Spanish colonists came over in greater numbers, and although patriarchal, women could inherit land and run businesses. The 18th to early 19th centuries signified turmoil in Europe. When Spain's king was thrown in jail and replaced by Joseph Bonaparte, the conflicting messages from Spain and the emergence of new technologies/economies spurred Mexico's calls for independence.

\subsubsection{Post-Colonial}

On September 16th, 1810, Mexico initiated its fight for independence from Spain. The "Grito de Dolores," or "Call of Dolores" by Catholic priest Miguel Hidalgo proclaiming that there should be equality and redistribution of land - symbolizes the movement towards independence (de Gobierno, 1916). It was not until August 24th, 1821 that general separation from Spain was recognized. Agustín de Itúrbide proclaimed himself emperor for a short time but was overthrown by general Antonio López de Santa Anna, who suggested the new country should be a republic and not continue as a monarchy. He then dominated politics for thirty years. 
An official constitution was written in 1824, and it established several democratic objectives and constructed the republic. In the $1850 \mathrm{~s}$, the next social reform took place. "La Reforma" sought to establish a standard of justice, remove relics of colonialism, separate church and state, and uplift small farmers/industries. Slavery was abolished, freedom of speech was fortified, and lands owned by the church and corporations (other than the buildings they used) were confiscated by the government, in a movement led by Benito Juarez (History.com, 2018). This move angered many powerful people and they sought help from elsewhere. Using their huge foreign debt as collateral, the French took their opportunity to install a puppet government. This led to the battle from Puebla now called "Cinco de Mayo" (note that it is not Mexican Independence Day). Benito Juarez ultimately regained power and continued strengthening Mexico's economy, communication and education.

The next period shaping Mexico's sociopolitical path was led by Porfirio Díaz from 1876 -1910. Porfirio followed the ideas of industrialization laid out by Benito Juarez but was a militaristic, brutal dictator who largely ignored the country's poor. In 1910 civil unrest was led by Mexico's middle class, stemming from the imbalance of power, and provoked the Mexican Revolution. After Porfirio was overthrown, a constitutional government was created. Agrarian reform during this period established and redistributed confiscated/hacienda land into an ejido, or commonly owned land, system (Parks, 2020).

In 1929, a political party later to be known as the Institutional Revolutionary Party (PRI) was formed, which held power in Mexico until 2000. An unequal distribution of wealth still exists in Mexico despite developmental advances made during the 20th century. In 1992, ejido land was made eligible to be bought and sold, and in 1994 Mexico ratified the North American Free Trade Agreement (NAFTA). This agreement, as well as an increasing rejection of neoliberalism, served as a catalyst for the largely women-led, Zapatista movement in the state of Chiapas. Perhaps more widely known for its efforts to keep genetically modified corn from inundating markets and collapsing the viability of local economies, the Zapatista movement aimed to challenge, once again, the disparity between the rich and poor in the country (Harvey, 1998). Around this same time, cartel related violence started to increase after the demise of the Colombian Cali and Medellín cartels and after key arrests were made within Mexican cartels, which resulted in a contest for power.

From 2007- 2018, it is estimated that 115,000 people were killed due to organized crime (Calderón, Heinle, Ferreira, \& Shirk, 2019). Creating terror within the social fabric of the country has been focused around gender-based violence. International attention was brought to the issue in the 1990's, when hundreds of women and girls went missing in the US-Mexico border city of Cuidad Juarez. Two-thirds of Mexican women 15 years or older have experienced some type of violence. Many journalists and scholars associate the increase in "femicides," or female gender-based murders, to 
the changing role women play in Mexican society, as they have new opportunities to enter the workforce and no longer have to depend on men to meet basic needs (Corradi $\&$ Bandelli, 2019). From 2015-2019, the number of femicides increased by $137.5 \%$, with only $6 \%$ of these crimes receiving a conviction (Lettieri, 2017). On February 9th, 2020 , the release of photos from a brutal femicide and lack of response from the Mexican government caused a wave of protests. To bring attention to the crisis, on March 9th, 2020, Mexican women "disappeared" from society for one day by not using social applications, going to work, or making any purchases (Villegas, 2020).

Mexico's history shows us how much the nation has been through, also how much it has overcome. Currently Mexico has a strong and growing economy, a young population and a diverse culture and environment. With the 2018 democratic election of Andrés Manuel López Obrador, Mexico is entering another period of change. There is new hope (and for some, fear) for reform in many areas such as the redistribution of power (decreased pensions for political figures), decentralization, increased educational opportunities, increased minimum wage, rejection of neoliberalism (Mexico first policies), increased social spending, legalization of marijuana, decriminalization of non-violent drug related incidents and many other areas, and hopefully in response to recent events, more security and protection for women (Villanueva Ulfgard \& Villanueva, 2020).

\subsection{Demographics}

\subsubsection{Population Statistics}

Mexico's population is estimated to be $128,649,565$, making it the 10 th most populated country on the planet (Central Intelligence Agency, 2020). In the Americas it comes in third behind Brazil and the United States. The social programs implemented in the 1930s caused Mexico's population to boom by reducing infant mortality and increasing life expectancy (Parks, 2020). Recently, population growth has been declining. Regardless of this slowing growth (1.04\% per year), Mexico has a young population (Figure 3.1). In 2009, half of the population was 25 or younger, and current estimates show the average age to be 29 years. Immigration has played an important role in the demographics of the population; migration in the country is -1.9 migrants per 1000 people - meaning more people are leaving than coming in (Central Intelligence Agency, 2020). Approximately $81 \%$ of the population lives in an urban environment and $21 \%$ live rurally. 


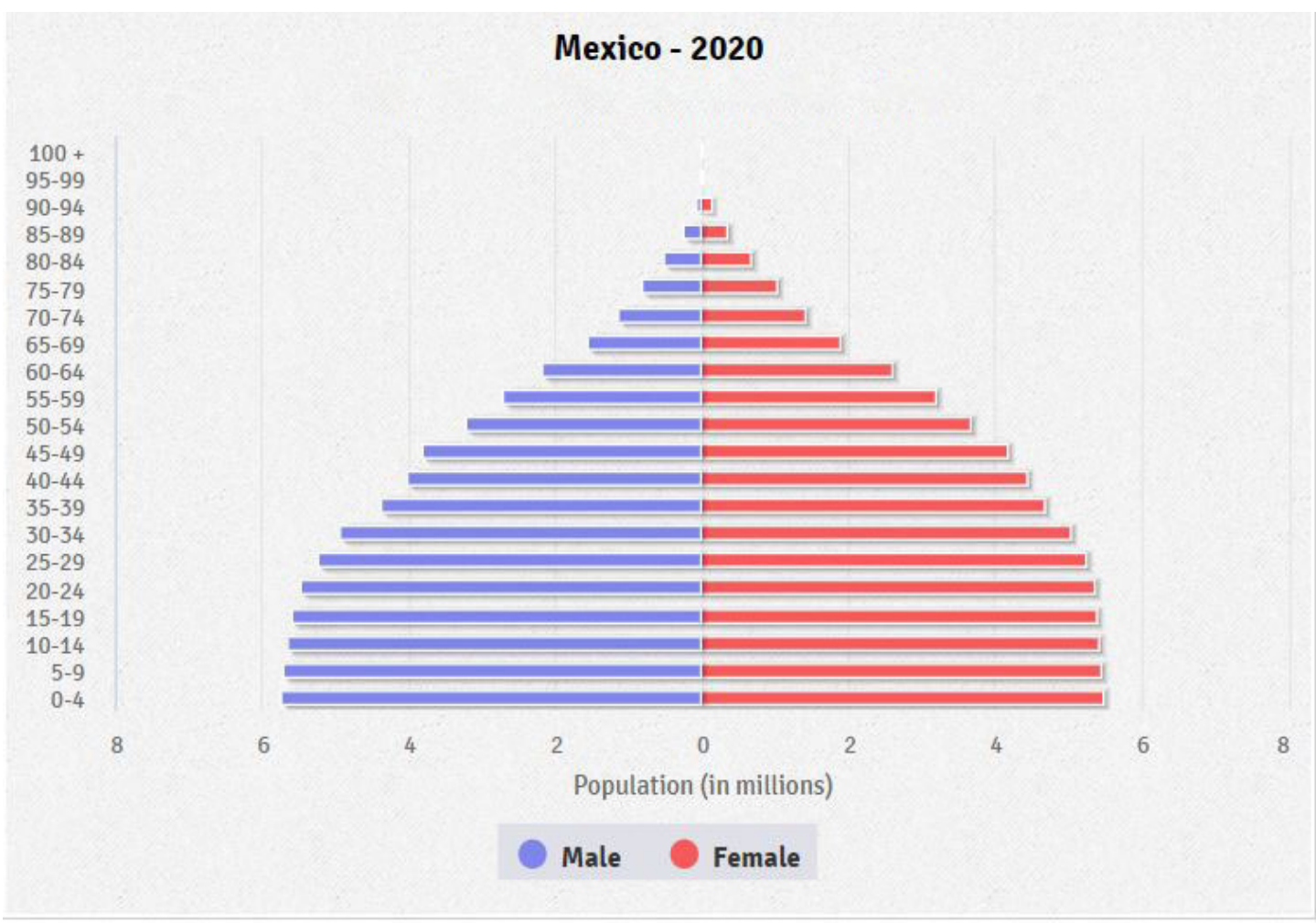

Figure 3.1: Figure of population age structure in Mexico (2018) (Central Intelligence Agency, 2020).

\subsubsection{Language}

The Spanish language is spoken by $98.3 \%$ of the Mexican population, making Mexico the largest Spanish-speaking nation in the world. Although Spanish is predominant, there are 68 recognized national languages -63 of which are indigenous. According to the National Institute of Indigenous Languages (INALI), which only uses distinct ethnic groups to classify a language, the number of languages present in Mexico is 282 (Lewis et al. 2018). These languages are derived from eleven different linguistic families. Perhaps not surprisingly, English is the second most spoken language in the country. After a long history of "castellanización", or converting indigenous language speakers to Spanish, only roughly $5 \%$ of the population speaks an indigenous language. The five most spoken indigenous languages are: Nahuatl (1,586,884 speakers), Yucatec Maya (796,405 speakers), Mixtecas languages (494,454 speakers), Tzeltal (474,298 speakers), Zapotecas languages (460,683 speakers), and 2,882,504 other language speakers (Biles, 2010). Unfortunately, many indigenous languages in the country are in danger of becoming extinct in the next few years or decades. 


\subsubsection{Education System}

Mexico spends 4.9\% of its GDP on education per year. $95.4 \%$ of the population 15 and over can read and write. K-12 schooling is mandatory and public schooling is free (Central Intelligence Agency, 2020). There are two types of high school: "Bachillerato" and "Preparatoria". Bachillerato is most comparable to vocational school and prepares students to work in various trades, whereas Preparatoria is most associated with students wishing to pursue their studies at a university. Public university is free/low cost and under President López Obrador, financial aid opportunities have increased.

\subsubsection{Ethnic Groups}

Mexico's census does not collect information on ethnicity; however, ethnic data can be described in the following ways: "Mestizos", or Amerindian-Spanish 62\%, Amerindian $28 \%$, and other 10\% (predominantly Europeans) (Parks, 2020). Amerindian signifies a person of American Indian descent. To this day, ethnicity matters in the distribution of wealth and class. Mexicans who look white or have European ancestry tend to occupy positions of power, while mestizos occupy a wide range of economic and social positions, and people of Amerindian descent tend to be subjugated to lower economic and social positions.

\subsubsection{Religion and Religious Education}

Although Mexico has no official religion (church and state are separated), religion permeates daily life from religious holidays, traditions, and celebrations to household décor and even cordialities/greetings (Figure 3.2). Abrahamic religions tend to dominate the country; Roman Catholicism has the most followers in the country at $82.7 \%$ (Miaschi, 2019). Over the years, different sectors of Christianity have gained popularity such as Pentecostal (1.6\% of the population), Jehovah's Witnesses (1.4\% of the population) and Evangelical (5\% of the population). Only $4.7 \%$ of the population subscribes to no religion.

Catholicism arrived in Mexico with the Spanish and has had a lengthy, and some might argue controversial, history. Even though the Spanish built their cathedrals over pagan temples, part of the success of the Catholic proselytization was incorporation of pagan Amerindian celebrations, symbology and artwork - the celebrations of Day of the Dead, use of shamans, similarity of pagan gods to the saints and so on (Wolf, 1958). Before the Juarez Law of 1855, the Catholic church owned approximately half of all the land and had control over schools, hospitals, and institutions (Thomson, 2018). Since 1970, Catholicism has waned but remains dominant culturally. 


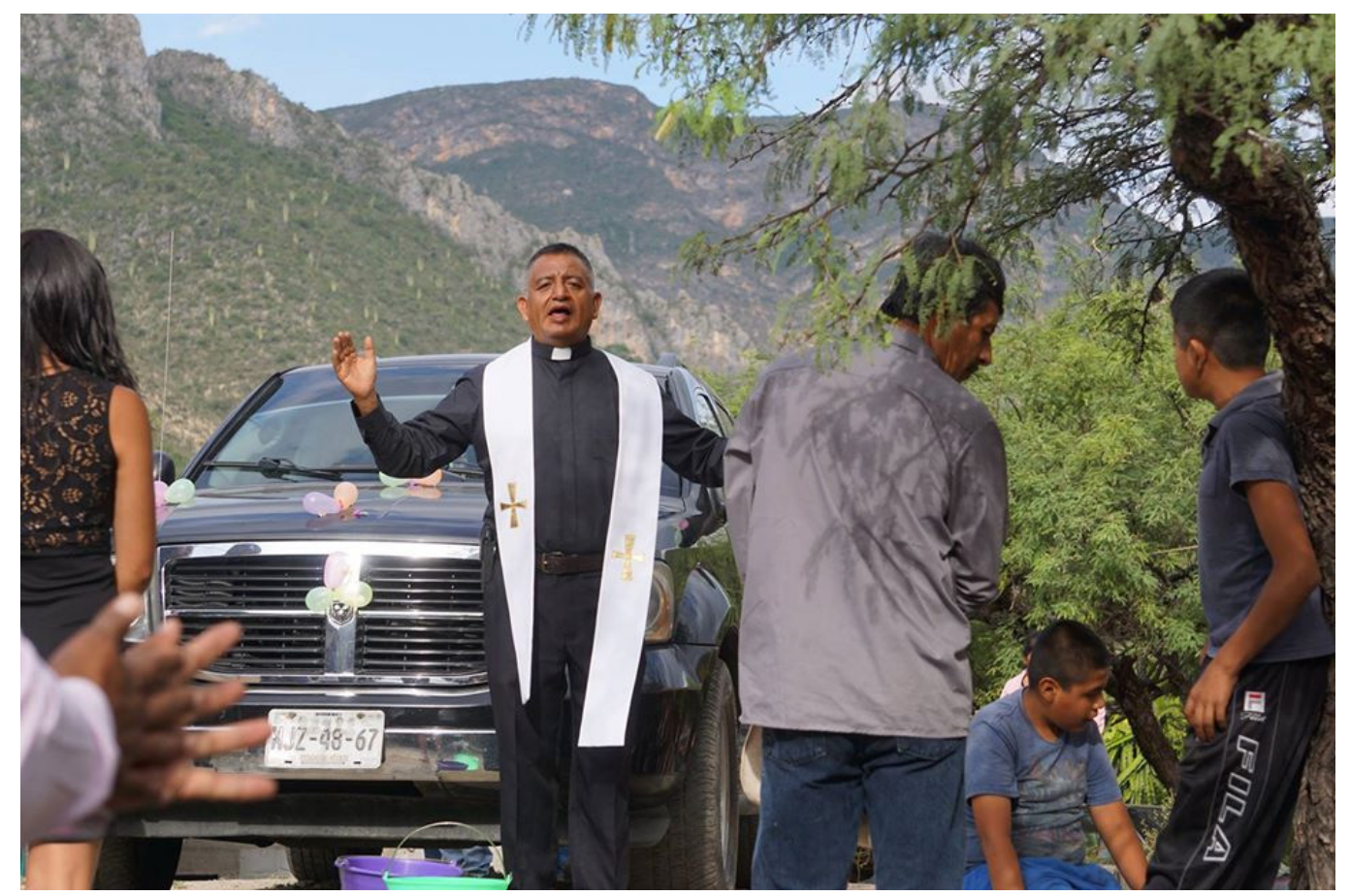

Figure 3.2: Catholicism is a key element of Mexican society (photo by the author).

\subsection{Land}

Although the country only covers roughly $1 \%$ of the Earth's surface, Mexico is just as diverse geographically and biologically as it is culturally. Its lands range from 18,000foot stratovolcanoes to tropical mangrove forests. Much of this diversity comes from its unique location on the Earth's surface. The Tropic of Cancer divides the country into two distinct climatic zones, with the country's topography also having a substantial effect. The majority of land in Mexico is communally owned - in certain circumstances, creating strengths for conservation, but in other ways creating a lack of incentive, depending on the priorities of local authority groups. Under the Secretary of Environment and Natural Resources (SEMARNAT), Mexico has formed several federal agencies focused on conservation of natural resources. Much of the conservation takes place on communally-owned land that has been designated as "Naturally Protected Areas." Although only roughly 13\% of Mexico is arable, the country has a plethora of natural resources it extracts, such as petroleum, silver, copper, gold, lead, zinc, natural gas, and forest products (Bada, 2018). In the coming century, Mexico will have much work to do to mitigate the effects of climate change predicted to impact the country. If there is anything true about Mexico, is that its land and people are resilient despite the challenges they face. 


\subsubsection{Physiography}

The position on the lithosphere where Mexico lies is mostly part of the North American Plate (Figure 3.3). Mexico belongs to a tectonic region known as the "Pacific Ring of Fire," where interactions between the North American Plate, the Pacific Plate, the Cocos Plate, Riviera Plate, and the Caribbean Plate produce an ever-changing physical environment through seismic and volcanic activity (Biles, 2010).

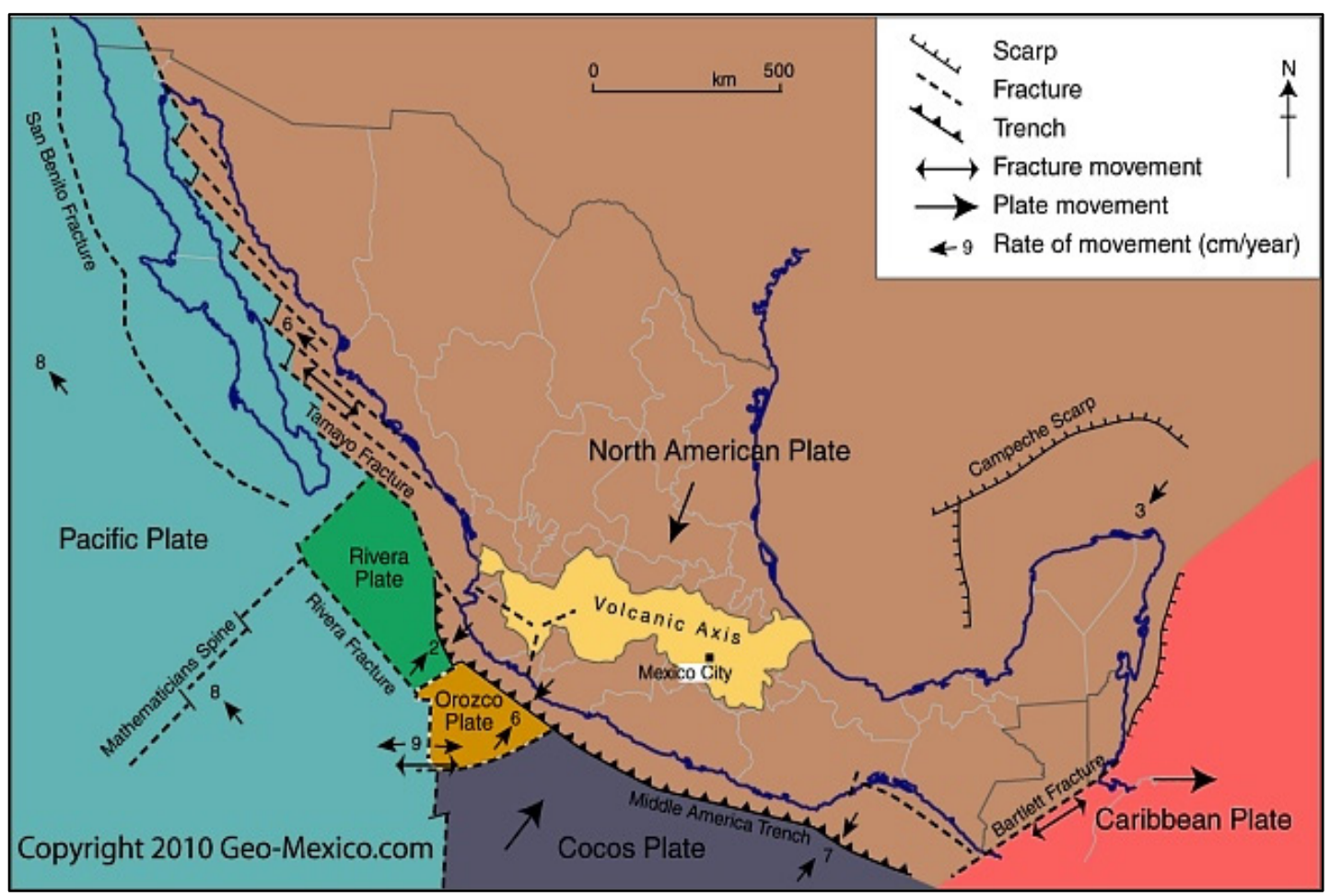

Figure 3.3: Tectonic plates in Mexico. Remarkably, it is the North American Plate's interaction with the Cocos Plate that has caused the major earthquakes in the last century (Figure by Tony Burton/Geo-Mexico, https://geo-mexico.com/?p=6277).

Depending on the source, Mexico can be divided into seven to fifteen physiographic categories. In this thesis I will use a nine-tiered system, with the understanding that categories can be described at different levels of detail (Figure 3.4). These nine regions are: Baja California, the Pacific Coastal Lowlands, the Mexican Plateau, the Sierra Madre Oriental, the Sierra Madre Occidental, the Cordillera Neovolcánica, the Gulf Coastal Plain, the Southern Highlands, and the Yucatán Peninsula (Parks, 2020). 


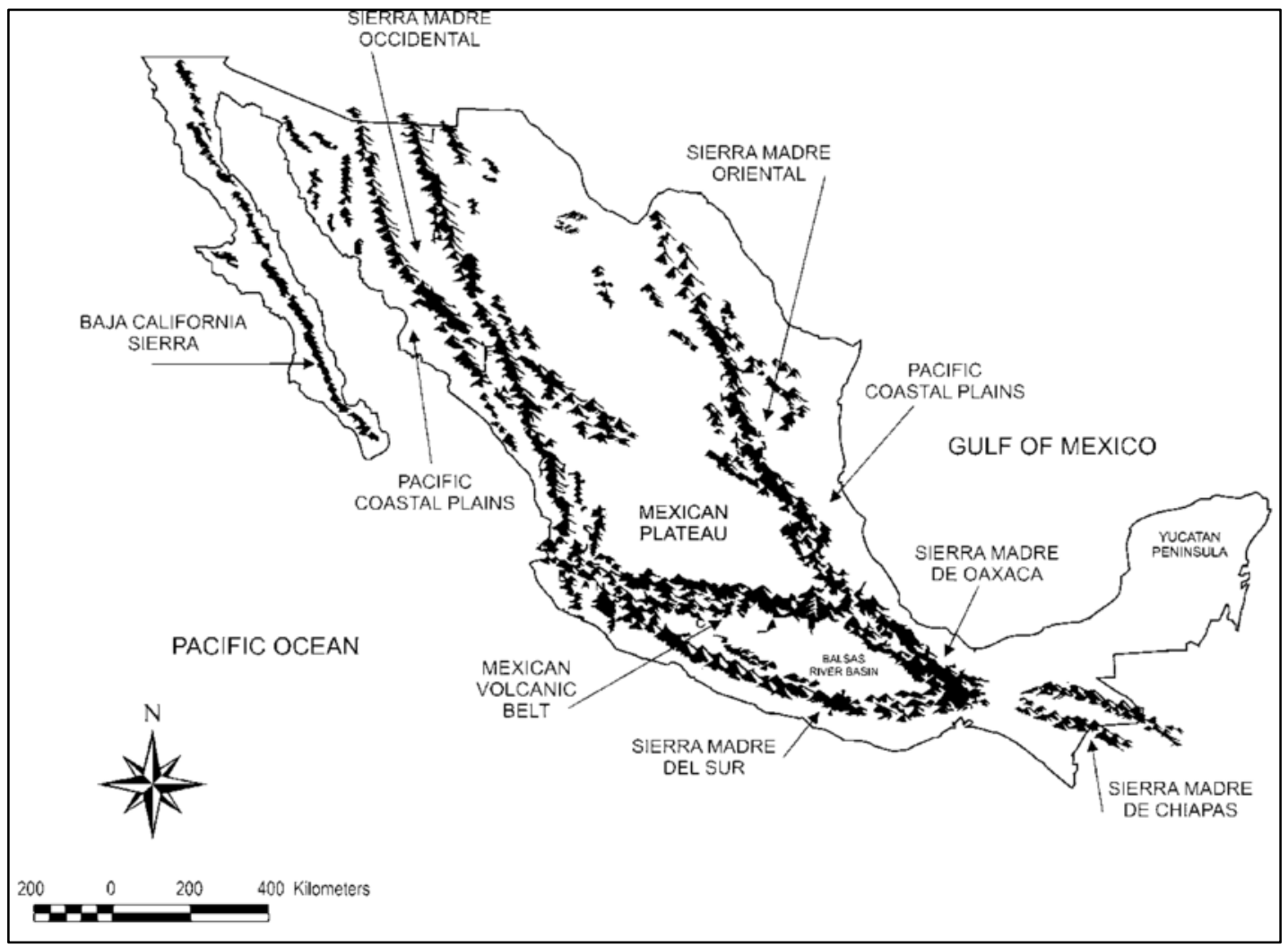

Figure 3.4: Map of 11 physiographic regions of Mexico (Alcocer \& Bernal-Brooks, 2010)

Many of these regions are defined by their dramatic topographical features. There are several large mountain ranges in Mexico, all of which have unique geologic features: the Sierra de Juarez and Sierra de la Laguna in the Baja Peninsula is predominantly Cretaceous granitic batholiths, Mesozoic-Tertiary clastic and volcanic; the Sierra Madre Occidental which runs along the west coast and consists of Tertiary lavas/pyroclastic on folded Mesozoic sediment-Paleozoic metamorphic; the Sierra Madre Oriental to the east, characterized by folded Mesozoic carbonates above folded Paleozoic sediments on top of Precambrian crystalline; the Cordillera Neovolcánica in the center of the country (Tertiary-Quaternary); the Sierra Madre del Sur to the south, (mid Paleozoic metamorphic); and also in the south, the Sierra de Oaxaca and the Sierra (and Highlands) de Chiapas (mid-late Cenozoic) (Alcocer \& Bernal-Brooks, 2010). The highest elevation is found on one of the volcanoes in the Cordillera Neovolcánica: el Pico de Orizaba, Veracruz, at 18,491 feet. Mexico's lowest point is Laguna Salada, in Baja California at 32.8 feet below sea level.

The geologic history of Mexico has affected its soils. Much of the territory surveyed in the country has been documented as Leptosols $25 \%$ (very shallow to bedrock). Other soil types that make up a significant proportion of the land area have been documented 
as 21\% Regosol (Entisol), 18\% Calcisol (Aridisol), 9\% Phaeozem and 7\% Vertisol (Distribution of soil types in Mexico. 2009).

Mexico has 5800 miles of coastline, the majority of which are on the Pacific coast. There are approximately 100 islands belonging to the country (The Diverse Islands of Mexico. 2019). Islands constitute 2317 square miles of Mexico's land base. Mexico's islands are in the Pacific Ocean, Caribbean Sea, Gulf of California and Gulf of Mexico.

From cenotes to naturally carbonated springs, Mexico's water resources are of great interest. CONAGUA has delineated 731 surface watersheds with 150 streams and rivers and 653 aquifers. Around $73 \%$ of the 51 million cubic feet of precipitation Mexico receives annually is lost through evaporation, $21 \%$ runs off into rivers, and $6 \%$ recharges the overdrawn aquifers (CONAGUA, 2015). Most major rivers in Mexico flow to the Pacific Ocean. Mexico experiences the effects of cyclones, drought and floods, all symptomatic of having too much or too little water.

\subsubsection{Climate}

Mexico's climate is constituted by dry, desert conditions to the north and tropical lowlands to the south. Though the Tropic of Cancer crosses the country and subsequently influences climatic zones, the most influential factor in Mexico's climate is its topography. The average temperature ranges from 50-90 degrees Fahrenheit, but that average changes based on altitude and location (Parks, 2020). The country experiences distinct wet and dry seasons. Typically, the rainy season begins in June and lasts until October. The dry season begins in November and ends in May. Although the average precipitation is somewhere between 700-800 millimeters per year, over 60 percent of Mexico is arid to semiarid, receiving less than 500 millimeters of water each year. The sub-tropics to the south account for this difference as they receive four times as much precipitation as the northern average per year.

\subsubsection{Biological Diversity}

Mexico contains roughly 10 percent of the Earth's species with over 200,000 species currently documented (CONABIO, 1998). It ranks number one in world for reptiles (707 documented species), second in the world for its number of ecosystems and mammals (438 documented species), and fourth in the world for overall number of species, flora (26,000 documented species), and amphibians (290 documented species).

Although Mexico currently has biodiversity-focused legislation, such as the law "NOM 059" that protects the country's biodiversity, the country's natural resources face a significant threat (Ambiente, P. F. D. P. A., 2016). Mexico depends on its biodiversity 
for many of its main economic activities - wood, fiber, food, fuel, medicine, alcohol fabrication, ecotourism, and more. Mexico ranks twelfth in the world for total forested cover. $30 \%$ of the country is covered by rainforest or other classes of vegetation. However, in recent years, $35 \%$ of the forest cover has been lost to deforestation (World Resources Institute. n.d.). It is estimated that over a quarter of Mexico's native ecosystems have been lost and what remains are under varying levels of conservation (Mexico - Country Profile, n.d.). Factors that most affect biodiversity loss in Mexico are climate change, population growth, urban growth, land use change, tourism, illegal markets (Asian countries play a large role), and poverty (dependence on natural resources).

\subsubsection{Land Tenure}

Land tenure defines who can hold and use land resources, with parameters of how long and under what condition (Assies, 2008). Mexico has had many periods of land ownership transitions and conflicts. Currently, there is a complex system of public, private and common land (Fernandez, 1943). This system is a direct result of haciendas being broken up by agrarian reform, land distribution following the Mexican revolution in the early 1900s and continuing into the 1980s, and lastly the land reform in the 1990s (Parks, 2020). During the agrarian reform period, 28,000 ejido (common) lands were formed, comprising roughly half of Mexico's available farmland. There are two types of communal land systems: bienes comunales and ejido. Though the distinction between them is somewhat ambiguous, the understanding is that bienes comunales was land designated for the use of indigenous communities and ejido land was distributed to the communities that worked on the haciendas.

In 1992, a land reform amendment was passed which sought to enable the privatization of common land. By enabling ejido members to sell their land (bienes comunales still cannot sell their land), the Mexican government hoped to create a dynamic land market and increase investment (Assies, 2008). However, even by 2006, only $1.6 \%$ of ejido land had been privatized. Central America, in general, has a history of land grabbing. When land is valuable to an outside interest group (domestic elite, government or corporation), there is an increased risk of exclusion and removal of agrarian peoples when the land rights are unclear (Bouquet, 2009).

Another crucial aspect of the Mexican tenure system is the role that gender has played in land access and ownership as well as cultural sovereignty. To this day only $26 \%$ of rural landowners are women (Miranda, 2019). Until recently, women did not play a role in local land leadership (comisariado groups), and even as they are able to participate in leadership, they often do not play a role in decision making. There are a few ways in which a woman can own a piece of land: she can inherit it, she can try to buy it subject to the approval by the town assembly (anyone who already owns land - 
usually males), or the assembly can choose to give it to her (teleSUR, 2019). For this reason, the percentage of women who own land has remained low despite reform.

\subsubsection{Land Protection Systems}

There are six land ownership systems in Mexico (federal, state, municipal, private, bienes comunales and ejido) which have different mechanisms for conservation. Only 28 percent of protected land is federally owned. There are several different types of federally protected lands (number of areas in parentheses): Biosphere Reserves (44), National Parks (67), National Monuments (5), Protected Areas of Flora and Fauna (40), Protected Areas of Natural Resources (8), and Nature Sanctuaries (18) (CONABIO, n.d.). Many states and even municipalities have their own system of conservation and have designated lands for protection (22 states). The vast majority of protected land is communal (especially when existing under federal regulation, e.g. Biosphere Reserves). The protected lands can be self-designated by the communal land leaders or they can agree to be a part of federally protected lands. Therefore, communally owned land that is protected can range from 1 acre to 100,000 acres. Private landowners can also designate land for conservation. These lands tend to be smaller in size, but they can have a major impact on conservation in the aggregate.

Environmental policies in Mexico began in the 1940s but it was not until the 1980s that serious thought was put into protecting Mexico's natural resources, and it was not until 2000 that the Secretary of the Environment and Natural Resources SEMARNAT was created (Cobb, n.d.).

SEMARNAT is responsible for the protection, restoration, and conservation of natural resources to promote sustainable development (SEMARNAT, n.d.). It is a complex organization and oversees other federal delegations to fulfill these functions. These entities are important for on-the-ground efforts for natural resource conservation and are divided by focus. There is the National Water Commission (CONAGUA), National Commission of Natural Protected Areas (CONANP), National Forestry Commission (CONAFOR), National Commission for the Knowledge and Use of Biodiversity (CONABIO), Mexican Institute of Water Technology (IMTA), Federal Attorney for Environmental Protection (PROFEPA), National Institute in Ecology and Climate Change (INECC), and the Agency for Security, Energy and Environment (ASEA). These federal agencies are the foundation of conservation in Mexico. Although in some respects, having public lands has been beneficial, it also has been linked to keeping much of the population in poverty because they have no personal stake in the land on which they work and live. 


\section{Tehuacán-Cuicatlán Biosphere Reserve Background}

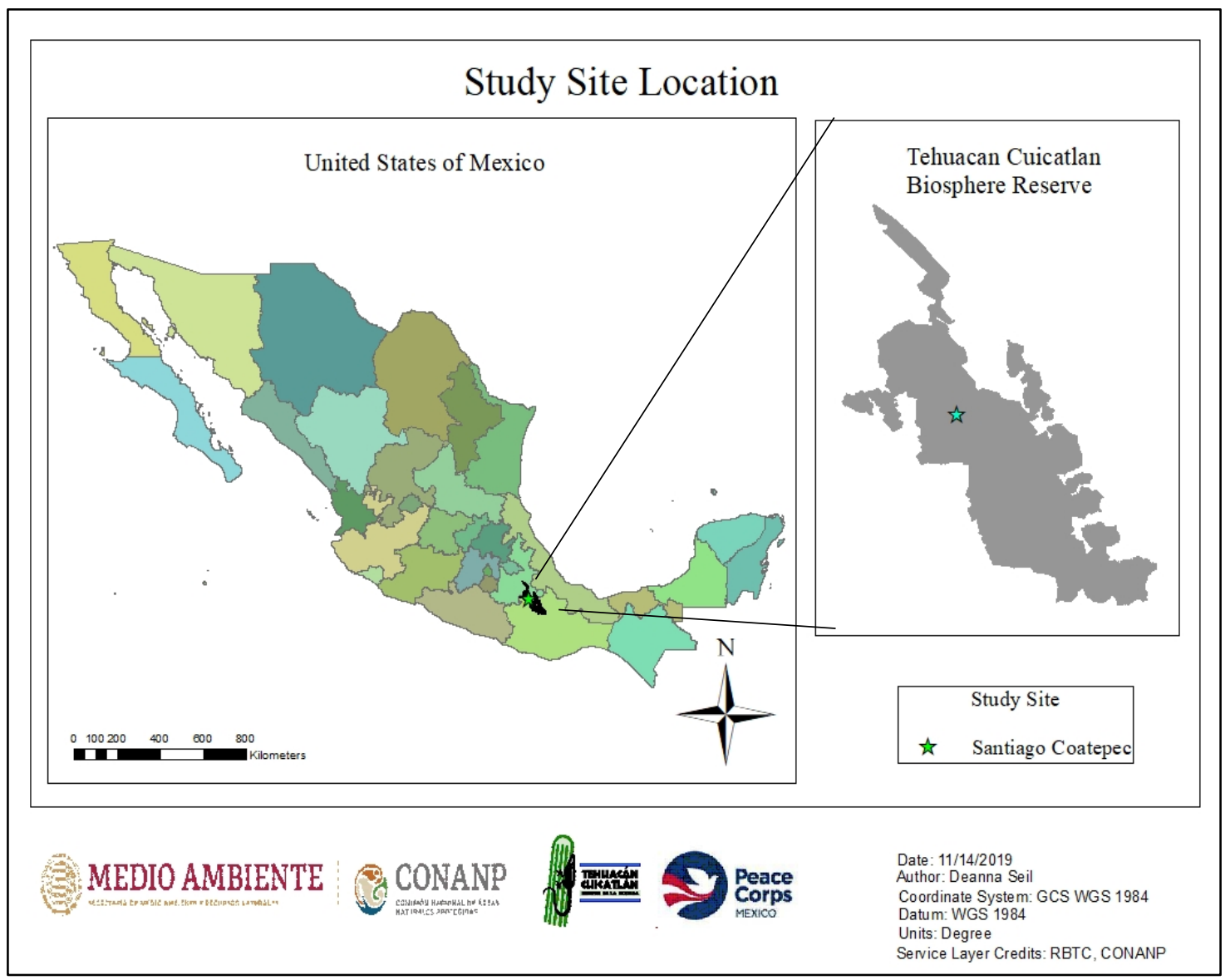

Figure 4.1: Tehuacán-Cuicatlán Biosphere Reserve (map by author)

The Tehuacán-Cuicatlán Biosphere Reserve (RBTC), located in southeastern Mexico (Figure 4.1), was declared a federally protected area in September of 1998 for its cultural and biological importance (CONANP, 2019).

\subsection{People}

\subsubsection{Population Statistics}

Spanning two states, Puebla and Oaxaca, the RBTC's core area of 490,186 acres is mostly communally owned as a result of land redistribution and reform during the 20th century. It is composed of 51 municipalities - 20 in Puebla and 31 in Oaxaca. Within the 51 municipalities there are 280 "nucleo agrarios," or common lands: $50 \%$ of the 
land is bienes comunales, $26 \%$ is ejidal, $8 \%$ is both and $16 \%$ is undefined agrarian. Although the area is a designated biosphere reserve, 35,000 people currently live within the protected area and have to abide by federal regulations. There are Náhuatl, Popoloca, Chochoteca, Mazateco, Cuicateco, Mixteco, Ixcateco and Chinanteco peoples within the reserve who have been there since time immemorial. Although certain communities' economically-driven migration has vastly altered the community structure, over the years 2003-2013 the part of the reserve within Puebla saw an increase of 4,226 inhabitants -- where the Oaxacan part of the reserve saw a decrease in 3,317 inhabitants.

\subsubsection{Anthropology}

Tehuacán for "place of the gods", and Cuicatlán "place that sings", the TehuacánCuicatlán Biosphere Reserve is considered to be the most biodiverse high desert ecosystem in the world. The Tehuacán Valley has been called the "birthplace" of modern agriculture; the first evidence of cultivated corn, avocados, chilies, beans, and squash were unearthed in caves that dot the edges of the valley (Mangelsdorf, 1964). This region also gave rise to innovative water management strategies. Mesoamerica's largest and oldest dam was located here to support the new agricultural demands, and human-constructed canals, terraces, wells, and aqueducts are also evident. UNESCO recognizes 22 archeological sites of importance, but the reality of this region is that there are likely hundreds, some in underexplored caves and still others in people's backyards (UNESCO World Heritage Centre, n.d.). In 2018, the Tehuacán-Cuicatlán Biosphere Reserve was named a World Heritage "Mixed" Site partially for this incredibly rich biological endemism, as well as its cultural importance.

Many of the technologies and customs are still found in practice today around the reserve. From the pre-Hispanic natural salt mines, the "metates" grinding stone and "molcajetes" grinding bowl, which date back to $5000 \mathrm{BC}$ are still used by local populations in the preparation of foodstuffs. The hand spun clay pottery still uses preHispanic technologies, as well as the palm weaving (ancient examples found in caves) - the current inhabitants of the region have carried on the traditions of the past (Mangelsdorf, 1964).

\subsubsection{Economic Activities}

Many of the economic activities which take place within the reserve are non-wage labor such as subsistence agriculture and household tasks (CONANP, 2013). Activities differ between states and even communities. These activities include the collection of insects, fruit (cactus and other plants), seeds, and palm leaves that are turned into hats, mats, and containers for tortillas. In drier regions, cultivation of tomatoes, tomatillos, corn, alfalfa, chilies, beans, wheat and squash takes place. In the tropical regions of the 
reserve, sugar cane, mangoes, bananas, papaya, dragon fruit, and limes are grown. Agave plants are grown and sold for reforestation as well as Mezcal distillation. Grazing activities are widespread within the reserve - mostly by goats.

In around the city of Tehuacán, Puebla, many of the primary economic activities are within the wage labor economy. Economic activities in this area are principally driven by large agribusiness (corn, alfalfa, barley, wheat, coffee, beans, chiote, chilies, squash, sugar cane, peaches, sapodilla), poultry farms both for eggs and meat birds (Mr. Egg, El Calvario, ALPES,PATSA, Huevo Tehuacán, and IMSA), pig farms (and other livestock industries), the service industry, shoe production, beverages (Peñafiel), and the textile industry (though the number is decreasing there are thought to be more than 300 "maquiladoras" within Tehuacán which produce clothes for companies such as Polo Ralph Lauren, Calvin Klein, Levi Strauss, Guess, and Gap) (Muñoz et al., 2013).

Remittances, or "remasas" of communities within reserve make up a large source of supplemental income. The municipalities with human settlements received over 107 million dollars in remittances in the year of 2013 alone (4.59 million dollars from the municipalities within Oaxaca and 102.03 Million dollars from the municipalities within Puebla (Sistema de Información Económica (SIE, Banco de México), n.d.). Although as a country, remittances make up $2.91 \%$ of Mexico's total GDP, within the reserve, this percentage is exponentially higher ("Mexico Remittances, percent of GDP - data, chart," n.d.). According to reporting of GDP per municipality in the year 2013, the communities within the reserve reported a total GDP of 37 million dollars - meaning that remittances were tripling the incomes of RBTC residents (INAFED, n.d.).

Mining of onyx, marble, clay, gravel, and salt occurs within the reserve boundaries (CONANP, 2013). The salt and clay mines have been active since Pre-Hispanic times. The clay and onyx are then transformed by local artisans into pottery and other goods.

Traditional wood harvest has occurred in the reserve for construction, cooking and other wood-based activities (mezcal fabrication etc). Forest management (harvest) for lumber/timber occurs principally in nine communities in Oaxaca (Santos Reyes Pápalo, Concepción Pápalo, San Martín Toxpalan, San Juan Bautista Atatlahuca Santa María Pápalo, San Miguel Maninaltepec, San Juan Teponaxtla, Zoquiapam Boca de los Ríos, San Juan Bautista Atatlahuca and San Juan Tepeuxila) (CONANP, 2013). Wood harvest has more recently been used to control the outbreak of the pine beetle.

Ecotourism is starting to take place within the reserve. Tourist attractions include the green macaws, the salt mines, an incredible botanical garden, interesting cuisine and paleontological remains such as the marine fossils and fossilized dinosaur footprints (Figure 4.2). 


\subsection{Physiography}

The reserve is characterized by deep valleys surrounded by mountains with impressive karst formations (Parks Watch, 2002). The topography ranges from 650 to 9800 feet; various morphotectonic events have led to the creation of complex high mountains, folded mountains, hills, volcanic domes, plateaus, tectonic faults, and valleys. Much of this region used to be ocean floor, so $85.6 \%$ of the reserve is sedimentary, mainly from the Cretaceous to the Tertiary. The region also has a history of volcanic and seismic activity, and the sedimentary rock is overlaid with igneous rocks $(4.9 \%)$ from the Paleozoic, Tertiary (Paleocene, Eocene, Oligocene), Superior (Miocene) and Quaternary (Pleistocene). In several areas in the reserve, one notes the presence of rhyolitic domes. Metamorphic rock (4.6\%) outcroppings from the Paleozoic and Precambrian era can be found in mountainous portions of the reserve. The valley also contains Quaternary sandstones and tamorconglomerates (López-Ramos 1981). The mountain ranges found within the reserve are the Sierra Madre del Sur to the northwest, the Mazatec Sierra in the middle, the Sierra de Juarez to the south and Sierra de Zongólica (Sierra Negra) mountains to the east. The soil taxonomy of the reserve is composed of Lithosols 35\%, Rendzina 25\%, Regosols 16\%, Feozem 11\%, Acrisols $6 \%$, Cambisols 2\%, Luvisols 2\%, Vertisols 1\%, Xerosols 1\%, and Fluvisols 1\% (CONANP, 2013).

The primary watersheds in the reserve are the Balsas (5\%) and Papalopan (95\%). Río Salado and Río Grande are sub-basins of the Papalopan watershed; within them there are 23 micro-watersheds (CONANP, 2013). The Balsas watershed is composed of Atoyac-Balcón del Diablo and Acatlán sub-basins and 6 micro-watersheds. 


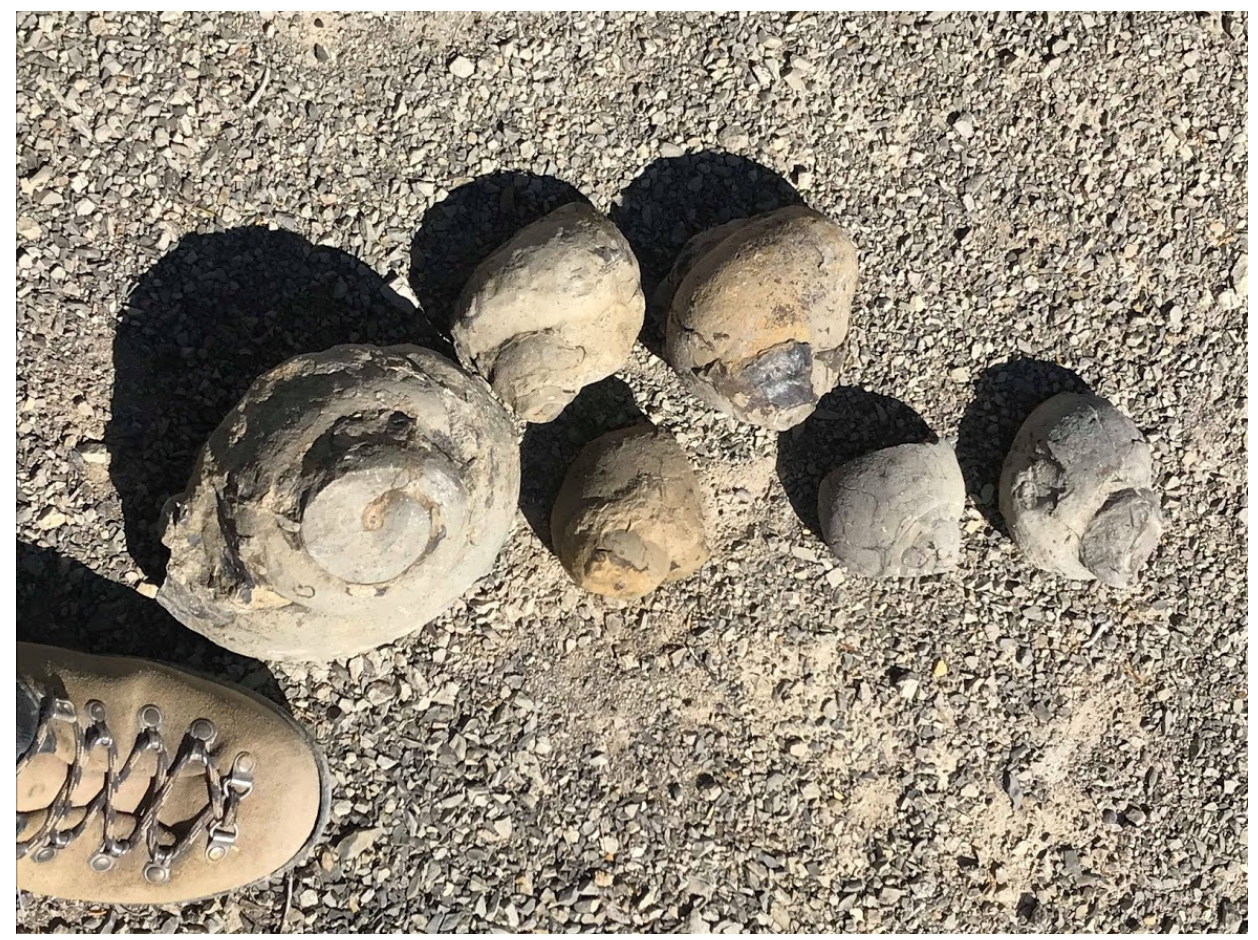

Figure 4.2: Fossils in the RBTC - Santiago Coatepec (photo by the author).

\subsection{Climate}

Mountain ranges surround the reserve and their convergence has created three distinct climatic zones: semiarid, temperate, and tropical. This area is the southernmost semiarid region on the continent. Average temperatures range from 64-71 degrees Fahrenheit around the valley and 75 degrees Fahrenheit in the Cuicátlan (tropical zone) (CONANP, 22013). The average annual rainfall, which primarily occurs in the months of June through September, is 250-500 millimeters (Enge \& Whiteford, 1989). Climate change models predict that there will be observed increases in average annual temperature, decreases in precipitation, and increases in aridity.

\subsection{Biological Diversity}

The abiotic factors defining this region - climate, topography, geology - have given rise to a unique center of biological abundance and endemism. Several systems are used to categorize the reserve's vegetation: Miranda's classification and Hernandez X. (1963) mentions 21 types of vegetation; Flores et al., (1971) notes 20 types, while Rzedowski (1978) describes 9 types of vegetation (CONANP, 2013). Using Rzedowski's classification system, the protected area is composed of $38 \%$ Tropical Deciduous Forest, 25\% Xerophilic (dry) Shrublands, Spiny Forest NA\%, Subtropical Deciduous Forest NA\%, Oak Forest 16\%, Coniferous Forest 5\%, Pine-Oak Forest 3\%, 
Juniper Forest NA\%, Cloud Forest NA\%, 4\% Grasslands, and Palm Forests $0.15 \%$. The "NA" signifying that these vegetation types are present but not measured.

There are currently 2,686 documented plant species in the reserve, 44 of which are endemic to the reserve. This number also considers the unique 'cactus forests' found in the region with 86 different species of cactus, $11 \%$ of which are Mexican endemics, and a density of 1000 cacti per acre (UNESCO World Heritage Centre, n.d.). The reserve is home to 338 species of birds and is part of the Balsas Region and Interior Oaxaca Endemic Bird Area (EBA). The RBTC supports nine endemic bird species, the largest population of green macaws, as well as the southernmost known golden eagle nest. There are 47 species of snakes - 33 non-venomous, 5 semi-venomous, and 9 venomous. Of the 134 species of mammals, 2 are endemic to the valley, 44 are bat species and 5 of the 6 neotropical feline species have been documented within the reserve. Even though most of the reserve is arid, there are 32 species of amphibians (the vast majority are threatened) and 18 fish species. For this diversity, the reserve is considered an IUCN biological hotspot; it contains 38 species listed on the IUCN Red List of Threatened Species.

\subsection{Land Protection and Threats}

Over the past twelve thousand years, the human-nature relationship has been pivotal in shaping and maintaining the biodiversity of this region. Modern times, however, have brought new threats to the reserve's biological stability: land use change, livestock introduction, the industrialization of extractive activities, infrastructure development, increased market demand for natural resources (rare cacti, cactus fruits, fibers, rare wildlife pets), increased public interest, increase in waste, low numbers of protected area staff, and now the looming effects of climate change.

Under the Secretary of the Environment and Natural Resources SEMARNAT, the National Commission of National Protected Areas CONANP is the principal agency responsible for the conservation of the RBTC. They work with local stakeholders (ejido, bienes comunales, NGOs, national volunteers, international volunteers, and other federal agencies) to achieve initiatives laid out in their 2013 Management Plan. Each year, community groups can apply to take part in federally-funded conservation projects. During 2017-2019, many of these projects were funded by the Program for Conservation for Sustainable Development (PROCODES). The reserve has fourteen full-time employees to orchestrate all conservation activities. 


\section{Literature Review}

Although this study focuses on one reserve, the implications of this research for conservation extend far beyond its boundaries. Human-wildlife conflict (HWC) is a global phenomenon; studies which utilize a multidisciplinary approach to measure conflict and the success of mitigation strategies are applicable to numerous scenarios around the world. Though there are studies which use camera traps, there are very few that work with ethological animal data and measuring the effect that livestock grazing has on wildlife behavior still has many areas for improvement. Therefore, this study brings together sociological and biological factors to cast a well-rounded image of measures taken to mitigate HWC in the small, but significant, community of Santiago Coatepec. The following literature helped inform many aspects of my research.

\subsection{Impact of livestock on wildlife}

For this thesis, I reviewed articles pertaining to the effect of livestock on native mammals. Schieltz \& Rubenstein (2014) conducted a review of the effects of livestock grazing on wildlife to gain a holistic viewpoint without innate biases. The article illuminates areas that lack adequate study to make concrete conclusions. The authors of this study analyzed 807 peer-reviewed papers, of which 646 were original studies. Of these articles, the vast majority were from North America (338) on birds (330) or mammals (262). The least number of studies came from Asia (31) and the least studied organisms were amphibians (58). This study only included studies written in English, however, so these numbers are incomplete. Of the 807 studies, there was a wide range in design and study quality. Components that affect the intensity of grazing, such as timing, duration, season, and frequency, are often not reported - grazing is predominantly described simply as "present" or "absent" on the landscape. Comparisons between wildlife responses to different grazing systems on wildlife responses are underexamined. Even though many of the studies show that livestock have negative impacts on wildlife, livestock management can also play an important role in habitat quality. There are several areas where properly grazed livestock might enhance habitat: forage base composition alteration, increased productivity of forage base (select species), nutritive value of forage increase, or altered structure of vegetation. The paper concludes that altering the structure of vegetation is most important to small mammals, reptiles and birds. Ungulates are most affected by changes in forage quality, forage quantity, and interference competition. Further research is needed on environmental conditions and species size and diets to make informed conclusions about livestock impacts on wildlife globally.

Jones (2000) summarizes studies on the impacts of cattle grazing on arid systems in the western United States. The paper points out that literature reviews can have an innate bias, since reviewers can choose to highlight certain studies that reinforce their own 
beliefs while finding ways to discredit studies that show contradictory findings. Therefore, the author attempts to explicitly control for bias, and considers 16 variables related to the impacts of grazing practices, which are then lumped into three main categories: soil, wildlife, and vegetation. The author uses a one-tailed statistical analysis to test the null hypothesis that grazing has no effect on arid systems. It found significant results in all three categories of variables (11/16 of the variables). The most drastic results were from the impact on soil erosion, bulk density, and infiltration - not on directly on wildlife. Grazing timing and intensity are not accounted for in this analysis. There are also many flaws in the experimental design of grazing studies. The author concludes that the findings in this study should only be used as a baseline for understanding of cattle grazing in arid conditions, and better-designed studies are needed in the future for rangeland specialists and livestock owners in order to make best decisions regarding grazing practices.

Finally, Hatten et al. (2002) wrote a foundational article on jaguar habitat range in the Southwestern United States. I used this article as a reference in order to create a map of suitable jaguar habitat in my region of the biosphere reserve. The study had two main objectives: 1) piece together potential jaguar range using historical sighting data and 2) create a statewide map of suitable habitat. The study found that the most crucial factors for jaguar habitat were proximity to water, habitat type, terrain type, elevation, and proximity to people. Jaguars have a varied diet so that is a less influential factor in where they may be found.

\subsection{Literature using camera traps for wildlife monitoring}

Camera traps have contributed valuable insights into the interactions among wildlife in reserves. One study within the Tehuacán-Cuicatlán Biosphere Reserve (RBTC) illuminated interspecific competition and its role in the structure of (primarily) carnivore communities. Botello (2006) found three fundamental aspects to be considered for co-occurring predators: space, activity and eating habits. In this study, he compared camera trap results from three different communities (San Francisco Cotahuixtla, San Lorenzo Pápalo, Santa Maria Tecomavaca) and collected over 3997 days of camera trap videos. His findings suggest that there was little temporal overlap among species, and little spatial overlap in niches, but food availability had a significant impact on ecological behavior of carnivores. The study found that competition for resources most influenced the structure of the biological community at the local level. This difference was found in 46 species, and this competition was exacerbated by fragmentation and human activity. Therefore, in the context of my study, a better understanding of anthropogenic pressure and fragmentation would yield a more complete understanding of carnivore dynamics and composition within the reserve. 
There are several important concerns when designing a camera trap study. One consideration is whether to use a single camera as a camera station or use a spatial capture-recapture (SCR) method with two cameras at each location to get both sides of an animal (Karanth \& Nichols, 1998). Another concern is how to design the study such that camera stations are spatially independent. Many studies use home range distances of the known species within the study area to determine minimum distances between cameras; lack of spatial independence can cause biased estimations (Lichstein, Simons, Shriner, \& Franzreb, 2002). Ensuring temporal independence of camera trap data is another important aspect to study design. Some researchers define independent events as thirty minutes between captures of and others define independent events as twentyfour hours between captures of the same species (Royle, Nichols, Karanth, \& Gopalaswamy, 2009). Another temporal consideration is that many analytical models do not account for multi-season studies, and those that do, do not analyze more than one species at a time. Data interpretation becomes more challenging in multi-purpose and/or multispecies studies. One major complication is that many species cannot be defined as individuals by markings alone, therefore, one must utilize study design features to accommodate for these potential issues. Many camera trap studies have found different mechanisms to overcome these analytical challenges. Sollmann (2018) gives a brief introduction to how camera trap data can be analyzed and presents the primary literature that outlines the rationale of the models developed. The review discusses photographic rates, occupancy, species richness, abundance (with or without individual identification), density, demographic features, activity patterns, and other parameters for analysis such as behavior.

The ability to calculate species richness via species accumulation curves is one of the many benefits of using camera traps. Species accumulation curves are the number of cumulative species detected against sampling effort (Gotelli \& Colwell, 2001). Photographic rates, signifying the number of independent captures per sampling effort, can be a useful facet of camera trap analysis. This calculation can determine activity indices of species at spatial, temporal, and behavioral levels (Sollmann, Mohamed, Samejima, \& Wilting, 2013). Photographic rates should be viewed not as a way to calculate abundance but as a way to estimate species activity/detectability. Occupancy of species refers to verification of species presence. This sounds simple but nondetection of a species does not mean its absence from the landscape (MacKenzie et al., 2002, 2006). Models by MacKenzie et al. (2002, 2006) were formulated under the assumption of imperfect species detection. Detection probability and occupancy probability are two different outcomes of occupancy analysis. Detection probability is the probability of a species being detected at a camera station at different times and occupancy probability is the probability that a species occurs at a site, which can be correlated with covariant information (site specific factors). Modeling occupancy requires that continuous camera trap data be broken up into different "occasions." When breaking the sample up into occasions one must be careful about breaking the 
sample into too many or too few samples, and the effect that temporary emigration may have on the outcome (Nichols et al., 2008). Abundance, density, and demographics information are best discerned for species with distinct markings, closed populations or with the SCR methodologies. The Royle-Nichols (2003) model allows for abundance to be estimated in unmarked animal populations through an extension of detection probability (occupancy) (Royle \& Nichols, 2003). There are also several other models that enable abundance to be calculated from unmarked populations (Chandler \& Royle, 2013; Rowcliffe, Field, Turvey, \& Carbone, 2008; Howe, Buckland, Després-Einspenner, Kühl, \& Matthiopoulos, 2017). Activity patterns can be analyzed with a model created by Ridout and Linkie (2009) which fits a kernel density function to the observed camera timestamps. Using camera trap data for behavioral analysis, however, is an area where camera trap analysis is in its infancy (Caravaggi et al., 2017).

\subsection{Ethnographic studies of HWC}

The Sierra Gorda Biosphere Reserve in Queretaro is a place with high levels of cultural and natural diversity. A study by Arroyo-Quiroz, García-Barrios, Argueta-Villamar, Smith, \& Pérez Gil Salcido (2017) paralleled some of my concerns based upon humanwildlife conflict (HWC) and resulting behaviors. Whilst attitudes towards wildlife may change positively, behaviors may not change all that much. HWC occurs when humans and wildlife compete for space and resources. It is thus imperative to gain an understanding of local attitudes towards wildlife competition for resources in order to design a well-functioning conservation plan. Attitudes such as tolerance are usually found in individuals who have a certain set of "personal values, relative wealth, level of education, extent to which monetary or other types of benefits are derived from wildlife and the magnitude of wildlife-associated costs (Naughton-Treves et al., 2003)." The study brings up an interesting and essential point that, at times, national agencies work more to protect the wildlife than to protect the local populations, thus making human communities feel "disadvantaged, unprotected, and vulnerable."

Arroyo-Quiroz et al. determined that it is of the utmost importance to design wildlife conservation programs to alleviate feelings of retribution. This means implementing feasible payment systems for livestock loss, building upon conservation practices to avoid HWC, and looking for the appropriate socio-ecological approaches to different community groups. It is important during the implementation of conservation programs to show communities positive, successful examples of other community-driven projects in the past - especially those where community members took an active role in the design, implementation, and analysis of such programs. In terms of who will take responsibility, the study brought up an important and interesting point that the Catholic Church, which has a lot of sway in many rural communities, should take more responsibility and take active steps in mentioning "stewardship of nature." 
Implementation of religious obligation may make it unnecessary to implement federal legal actions.

A compelling and interesting take on human-wildlife conflict comes from the Dickman's (2010) study on the impact and complexity that social dynamics brings to the issue (Dickman, 2010). HWC is not simply caused by man-eating tigers, but can encompass a wide range of situations such as crop-raiding of stored food, transmission of disease to livestock or humans, or even the imposition that wildlife presence places upon people who have to forgo certain economic pursuits (Pimentel, Zuniga \& Morrison, 2005; Thirgood et al., 2005; Woodroffe, Thirgood \& Rabinowitz, 2005). As human populations expand into previously uninhabited areas, HWC has been on the rise. Lethal control is still the predominant tool used in response to these situations. Unfortunately, even after long-term conflict reduction strategies have been applied, animosity towards wildlife often persists. To understand this persistence, the author notes that $\mathrm{HWC}$ is often driven more by underlying human-human dynamics than direct wildlife damage. In order to create long lasting results, one must understand specific local conditions that impact underlying risk. Three influential factors should be considered when determining a mitigation strategy: social sway, conception of risk, and disparate responses.

People base their opinions not on facts and personal experience alone, but on a multitude of societal factors and cultural beliefs. Wild animals have been woven into mythology and folklore (such as vampirism in bats), signifying that even after a conflict has been mitigated, deep-seated fear of that animal will almost certainly persist (Prokop et al., 2009). Human-wildlife conflicts are often infused with human-human dynamics and reactions fluctuate more as a result of social change than change in damages incurred. In Tanzania, spotted hyenas (Crocuta crocuta) have been subject to disproportionate actions due to conjectures that certain ethnic groups can bewitch them and train them to kill other groups' livestock. Perception of risk is also influenced by in situ factors such as history, cultural values, ideologies and beliefs about "what the world 'should' be like" (Boholm, 1998; Sjoberg, Moen \& Rundmo, 2004). A study by Starr (1969) found that people were one thousand times more likely to respond normally when they undertake risks voluntarily as opposed to having risks imposed upon them (Starr, 1969). Populations living within conservation areas may have more underlying resentment and suspicion towards protected wildlife and may take more severe actions if the opportunity arises (Skogen et al., 2008). In addition to what is inherently fear-provoking, people are afraid of what is novel to them. Human communities living in near protected areas may also have less fear of wild animals (Røskaft et al., 2003). Hyperawareness of risk can arise at both individual and local levels. Individuals can exaggerate the conflict they experience, and a community can take on the fear of the loss sustained by an individual, even if other members have never had it happen themselves. Misconceptions of "fear-worthy" animals are often 
propagated by popular culture - take the movie "Jaws" for example; people are afraid of sharks even though the risk of attack is minuscule (Harrison \& Cantor, 1999).

Communities that are dependent upon a natural resource as their primary source of income may be especially vulnerable and react disproportionately to human-wildlife conflict due to lack of alternative economic strategies. Here it is noted that risk of a conflict is not the same as vulnerability to it. Coping strategies for vulnerable populations are essential to long-term conflict reduction. It has been seen that people respond to minor conflicts with disproportionately severe responses. Even in cases where conflict no longer is an issue, hostility remains, as seen in the case where cheetah populations in Namibia are still eliminated by local farmers even though they no longer experience damages (Marker, 2002). Belief systems also play a role -Christianity can play an antagonistic role in wildlife perceptions (Hazzah, 2006). Environmental factors such as location of assets, land management practices, and lack of available resources can impact conflict. Actions can be taken to reduce risk in these factors, such as better guarding of assets through the use of guarding dogs and fences. When implementing conflict mitigation strategies, it is of the utmost importance to ensure that you are not simply displacing the conflict onto another population, especially in areas where friction between groups already exists. To move towards coexistence, mitigation attempts must become increasingly innovative and involve interdisciplinary teams. 


\section{Methods}

\subsection{Study Site}

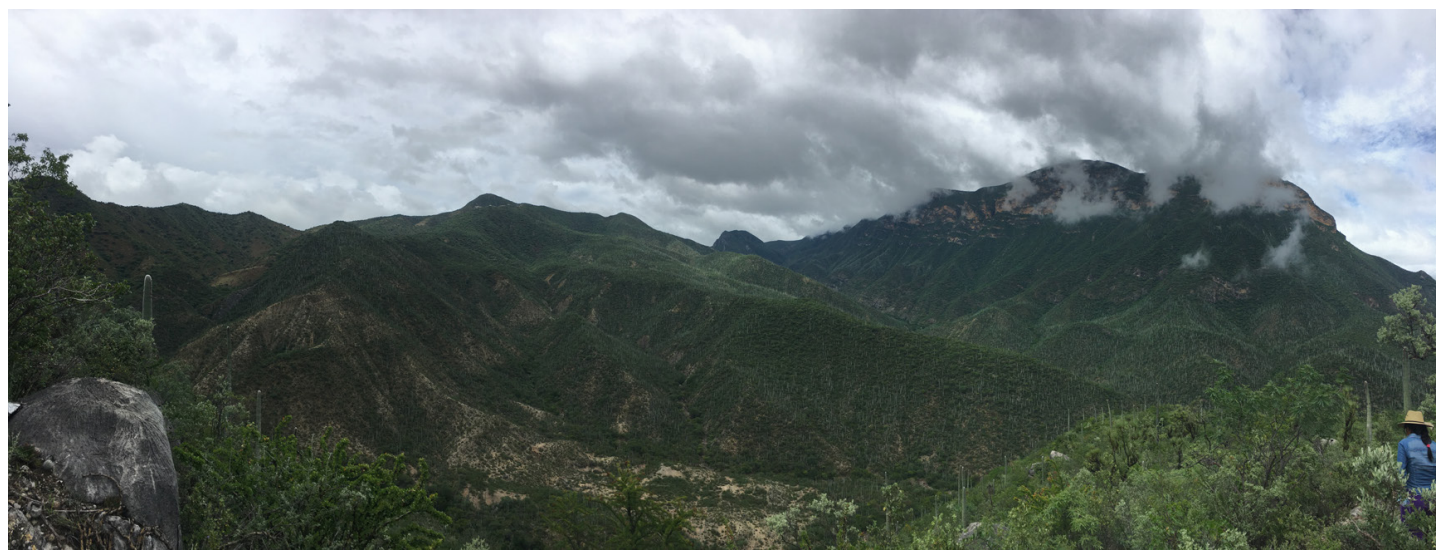

Figure 6.1: Study site during the wet season (photo by the author).

This study was completed in the town of Santiago Coatepec, municipality of Caltepec, Puebla located in the Tehuacán-Cuicatlán Biosphere Reserve. This location was chosen not only because it was my host site location for Peace Corps, but also seemed a good representative of the reserve's wide ranging ecological and cultural diversity.

The community is nestled in the Sierra Madre del Sur mountain range (Figure 6.1). The community itself is located at 5,700 feet, but the elevation ranges from 3900-7500 feet and is primarily described as a semi-arid, temperate climate BS1hw (Köeppen classification, modified by García, 2004). The average temperature is 71 degrees Fahrenheit and the average rainfall is between 400-500 millimeters per year (CONANP, 2013). The area has had several geologic events that have resulted in a complex geological constitution ranging from sedimentary deposits from the Paleozoic Superior (PS), metamorphic intrusions from the Precambrian (PE) and igneous gneiss from the Paleozoic (Eje Neovolcánico Transversal). The predominant soil type is Lithic and Eutric Leptosols (very shallow soils) and secondary soils are Regosols (also poorly developed mineral soils). Although there is very little soil build up, the native plant communities thrive in these harsh conditions. In Coatepec, the vegetation is mainly Low Deciduous Forest (Selva Baja Caducifolia), Succulent Shrubland (Matorral Crassicaule -arbustiva), Succulent Shrubland with Nopals (Matorral Crassicaule con Nopalera), Rostephille Desertic Shrubland (Matorral Desértico Rostetofolio arbustivo). The area is part of the Papaloapan watershed. There are seasonally dry riverbeds which flow into Rio Hondo (Deep River), and the area contains 7 commonly known natural springs -2 of which are undrinkable salt/mineral springs. The land falls under two management categories defined by CONANP - traditional use and preservation. 
The community is broken up into two "nucleo aragios," or common land management systems - Bienes Comunales (1254 acres) and Ejido lands (1923 acres); the total community land is 5511 hectacres (CONANP, 2013) Each nucleo agrario had their own governance and had varying interest in different projects. Within the community, the 427 residents primarily partake in non-wage labor economies: subsistence agriculture, livestock husbandry, wood collection and household tasks. $26 \%$ of the population is engaged in wage labor (only 5\% women) such as dragon fruit production, embroidery, mezcal fabrication, agave nurseries, small stores, and avocado harvesting (Coatepec, n.d.). Despite having low percentages of participants involved in the wage economy, only $2.38 \%$ of households in the county receive remittances which summed up to 55,045 thousand dollars in 2019 (Hernández Juárez \& Morales Cantu, 2014; Sistema de Información Económica (SIE, Banco de México), n.d.). This does not consider the money being sent from cities within Mexico - which may a significant source of supplemental income for the municipality and its communities. Many people have also left the community in order to seek work in Tehuacán and larger cities in Mexico. Only $3 \%$ of the community is considered indigenous and there are 2 speakers of Nahuatl. 31.25 hectares have archeological importance, primarily the settlement in Santa Lucia and the top of Cerro Viejo. There are 166 houses and 97\% of the dwellings have electricity, $71 \%$ have piped water, and $97 \%$ have an outhouse or bathroom (Coatepec, n.d.).

Santiago Coatepec is located 3 hours by bus to the nearest city of Tehuacán, Puebla. The primary mode of transportation around the community was by foot, donkey or horse and the primary mode of transportation out of the town was by public bus. 


\subsection{Wildlife Monitoring}

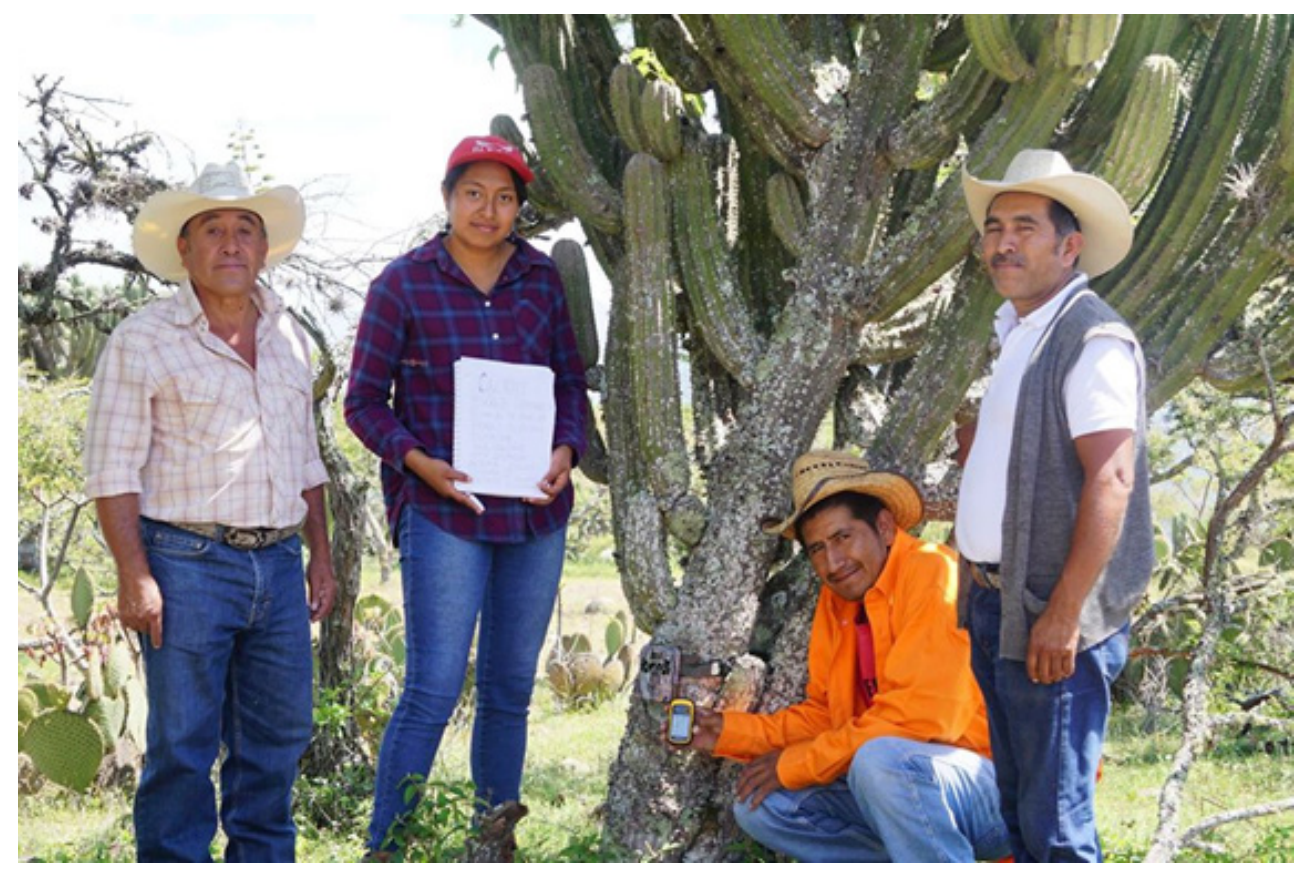

Figure 6.2: Caltepec Bienes Comunales during camera trap monitoring (photo by the author)

Camera traps can be used to detect local wildlife community composition, richness, and structure. They offer a non-invasive, low-labor way to collect robust data which can additionally record animal behaviors (Kays, 2009, Cusack, 2015). Camera traps can record animal behaviors with minimal interference from observers. They can also be used to detect local wildlife presence, distribution, predator-prey relationships, and density. Kays et al. (2011) outlines methodologies and discusses camera trap monitoring protocols and tendencies, such as baiting, camera trap location, time frame, the distance between cameras, the time between the collection, time of study and trigger settings (video vs photo, the delay time between captures and time-lapse). Studying wildlife movement through camera-trap projects is important to deciphering the impact of habitat loss, climate change, invasive species, infectious disease, and other environmental challenges.

Camera trap data of species presence, type, distribution, and abundance can help impact conservation actions. However, choosing appropriate methodologies is key to producing unbiased results, especially when cameras capture such a small portion of vast and dynamic landscapes where species utilize different habitat types. Cusack et al. (2015) shows the results of two placement strategies: non-random (using trail or landscape features) or random camera placement. Historically, using non-random placement has been most common, and calculating bias is an important aspect of this 
design. Interestingly, the climatic details of the Ruaha National Park studied by Cusack et al. (2015) match that of the RBTC - even in terms of floral species composition. Ultimately this study found that while placement technique did not affect the results of community structure, it did influence richness and composition during the wet season.

Community driven monitoring was implemented using the Eulerian approach - or monitoring from one single location - using non-random camera trap placement over nineteen months starting September 2017 and ending in June 2019 (Kays, 2009). I used six cameras divided between the Ejido and Bienes Comunales groups equally. Locations of the cameras were non-randomly chosen by communal leadership members using historical knowledge of wildlife movement, landscape features, and trails (Figure 6.3). With enough sampling effort ( $>1400$ camera days), there is minimal impact of placement technique (non-random versus random) on observations of species composition, richness and structure (Cusack et al., 2015). Additionally, allowing the local leadership to have input was crucial to maintain interest and involvement in the study. This meant that at times, cameras were also used for the community leader's own surveillance purposes. Some camera stations were highly trafficked human routes, making the impact of human presence also quantifiable. All cameras, including the ones specifically used for human surveillance (theft etc.), were placed at sites with signs of wildlife, mainly along or near trails or at springs. Diverse habitats and altitudes were also important camera placement factors to capture a diverse set of wild animals, as many sympatric species occupy different niches in a heterogeneous landscape.

During field monitoring, data were collected such as GPS locations, date, time, elevation, station name, and camera number, as well as vegetation, bird species, animal signs and tracks, and environmental threats (Appendix C). A minimum of 1 mile (1.6 $\mathrm{km}$ ) was used between camera locations to reduce the chance of recapturing the same individual. This distance was chosen on the recommendation by CONBIODES personnel and previous research regarding multispecies mammalian populations (Silviera et al., 2003). . Exact distance recommendations for multispecies research vary by study and remain an area of active investigation (eMammal, n.d.). Camera traps were typically placed $30 \mathrm{~cm}$ above the ground (knee height) on sturdy bases. Cameras were angled to capture front and side views of wildlife to enable more accurate identification of distinct individuals. Placement was also dictated by avoiding high shadow movement, windy locations, or other site-specific variables which could cause false triggers. Cameras were equipped with 16 GB Sony SD cards that could capture roughly 125 videos. Cameras were programmed to capture 20 second videos with a delay of 5 seconds between each camera trigger. Camera traps were visited every 30 days to download the videos from the cards. At the start of each camera period, a data sheet was placed in front of the camera with the following points: communal land system, date, time, UTM coordinates, altitude, camera number, and camera station name. Over the nineteen-month period, 18 camera stations were used, with a minimum of 5 footage days and 30 camera days at each location (Table 6.1). 
Data from each wildlife monitoring event was placed into an Excel database, and tracks and waypoints were uploaded into mapping software to create maps of the study area. Using the buffer of 1 mile between camera stations, the total camera-surveyed area was 14.3 square miles (Figure 6.3).

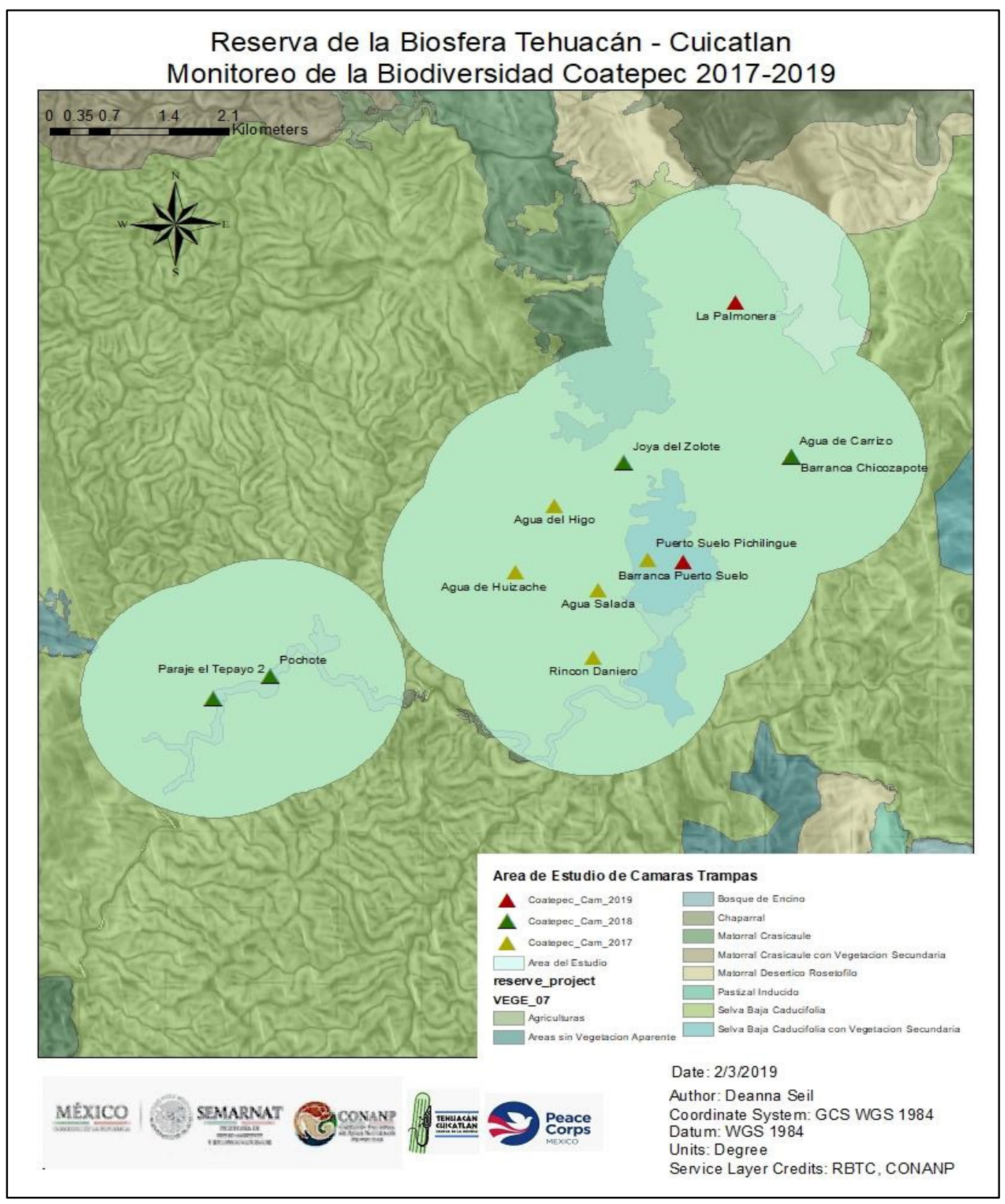

Figure 6.3: map of the study area (map made by the author) 
Table 6.1: Table of camera trap stations and covariate information (table by the author).

\begin{tabular}{|c|c|c|c|c|c|c|}
\hline $\begin{array}{l}\text { Coun } \\
t\end{array}$ & $\begin{array}{l}\text { Camera } \\
\text { Station }\end{array}$ & $\begin{array}{l}\text { Land } \\
\text { System }\end{array}$ & $\begin{array}{l}\text { Latitud } \\
\text { e }\end{array}$ & $\begin{array}{l}\text { Longitu } \\
\text { de }\end{array}$ & $\begin{array}{l}\text { Altitud } \\
\text { e }\end{array}$ & Landform \\
\hline 1 & $\begin{array}{l}\text { Joya del } \\
\text { Zotole }\end{array}$ & $\begin{array}{c}\text { Bienes } \\
\text { Comunal } \\
\text { es }\end{array}$ & $\begin{array}{c}18.1281 \\
0\end{array}$ & $\begin{array}{c}- \\
97.36844\end{array}$ & $1566 \mathrm{~m}$ & Hill \\
\hline 2 & $\begin{array}{c}\text { Puerto } \\
\text { Suelo } \\
\text { Pichilingu } \\
\mathrm{e}\end{array}$ & $\begin{array}{c}\text { Bienes } \\
\text { Comunal } \\
\text { es }\end{array}$ & $\begin{array}{c}18.1171 \\
3\end{array}$ & $\begin{array}{c}- \\
97.36593\end{array}$ & $1334 \mathrm{~m}$ & Hill \\
\hline 3 & $\begin{array}{l}\text { Agua del } \\
\text { higo }\end{array}$ & $\begin{array}{c}\text { Bienes } \\
\text { Comunal } \\
\text { es } \\
\end{array}$ & $\begin{array}{c}18.1231 \\
0\end{array}$ & $\begin{array}{c}- \\
97.37575\end{array}$ & $1522 \mathrm{~m}$ & Spring \\
\hline 4 & $\begin{array}{c}\text { Barranca } \\
\text { Chicozapo } \\
\text { te } \\
\end{array}$ & $\begin{array}{c}\text { Bienes } \\
\text { Comunal } \\
\text { es } \\
\end{array}$ & $\begin{array}{c}18.1287 \\
4\end{array}$ & $\begin{array}{c}- \\
97.35072\end{array}$ & $1282 \mathrm{~m}$ & Streambed \\
\hline 5 & $\begin{array}{c}\text { Barranca } \\
\text { Puerto } \\
\text { Suelo } \\
\end{array}$ & $\begin{array}{c}\text { Bienes } \\
\text { Comunal } \\
\text { es } \\
\end{array}$ & $\begin{array}{c}18.1175 \\
2\end{array}$ & $\begin{array}{c}- \\
97.36257\end{array}$ & $1552 \mathrm{~m}$ & Streambed \\
\hline 6 & $\begin{array}{c}\text { La } \\
\text { Palmonera }\end{array}$ & $\begin{array}{c}\text { Bienes } \\
\text { Comunal } \\
\text { es } \\
\end{array}$ & $\begin{array}{c}18.1465 \\
1\end{array}$ & $\begin{array}{c}- \\
97.35683\end{array}$ & $1765 \mathrm{~m}$ & Cliff \\
\hline 7 & $\begin{array}{c}\text { Agua de } \\
\text { Guayabito }\end{array}$ & $\begin{array}{c}\text { Bienes } \\
\text { Comunal } \\
\text { es }\end{array}$ & $\begin{array}{c}18.1313 \\
9\end{array}$ & $\begin{array}{c}- \\
97.36139\end{array}$ & $1287 \mathrm{~m}$ & Streambed \\
\hline 8 & $\begin{array}{c}\text { Agua del } \\
\text { Carrizo }\end{array}$ & $\begin{array}{c}\text { Bienes } \\
\text { Comunal } \\
\text { es } \\
\end{array}$ & $\begin{array}{c}18.1281 \\
3\end{array}$ & $\begin{array}{c}- \\
97.35861\end{array}$ & $1255 \mathrm{~m}$ & Spring \\
\hline 9 & El Rincon & Ejido & $\begin{array}{c}18.1048 \\
9 \\
\end{array}$ & $\begin{array}{c}- \\
97.36986 \\
\end{array}$ & $1336 \mathrm{~m}$ & Streambed \\
\hline 10 & $\begin{array}{c}\text { El Rincon } \\
\text { Danero }\end{array}$ & Ejido & $\begin{array}{c}18.1059 \\
0\end{array}$ & $\begin{array}{c}- \\
97.37169\end{array}$ & $1356 \mathrm{~m}$ & Streambed \\
\hline 11 & El Tepayo & Ejido & $\begin{array}{c}18.1024 \\
4\end{array}$ & $\begin{array}{c}- \\
97.41041\end{array}$ & $1360 \mathrm{~m}$ & Farmland/River \\
\hline 12 & $\begin{array}{c}\text { El Pochote } \\
2 \\
\end{array}$ & Ejido & $\begin{array}{c}18.1075 \\
0\end{array}$ & $\begin{array}{c}- \\
97.40613 \\
\end{array}$ & $1372 \mathrm{~m}$ & $\begin{array}{c}\text { StreambedFarmland/Ri } \\
\text { ver }\end{array}$ \\
\hline 13 & $\begin{array}{c}\text { El Tepayo } \\
2\end{array}$ & Ejido & $\begin{array}{c}18.1011 \\
3\end{array}$ & $\begin{array}{c}- \\
97.41191 \\
\end{array}$ & $1369 \mathrm{~m}$ & Upland/Farmland \\
\hline 14 & $\begin{array}{c}\text { Agua } \\
\text { Salada }\end{array}$ & Ejido & $\begin{array}{c}18.1136 \\
8\end{array}$ & $\begin{array}{c}- \\
97.37112 \\
\end{array}$ & $1382 \mathrm{~m}$ & Hill \\
\hline
\end{tabular}




\begin{tabular}{|c|c|c|c|c|c|c|}
\hline 15 & El Pochote & Ejido & $\begin{array}{c}18.1036 \\
6\end{array}$ & $\begin{array}{c}- \\
97.40578\end{array}$ & $1344 \mathrm{~m}$ & Farmland/River \\
\hline 16 & El Corral & Ejido & $\begin{array}{c}18.1039 \\
4\end{array}$ & $\begin{array}{c}- \\
97.39696\end{array}$ & $1323 \mathrm{~m}$ & Farmland \\
\hline 17 & $\begin{array}{l}\text { Agua de } \\
\text { Huizache }\end{array}$ & Ejido & $\begin{array}{c}18.1156 \\
4\end{array}$ & $\begin{array}{c}- \\
97.37994\end{array}$ & $1464 \mathrm{~m}$ & Farmland \\
\hline 18 & Savido & Ejido & $\begin{array}{c}18.1136 \\
8\end{array}$ & $\begin{array}{c}- \\
97.37112 \\
\end{array}$ & $1452 \mathrm{~m}$ & Streambed \\
\hline
\end{tabular}

\subsection{Interview Collection}

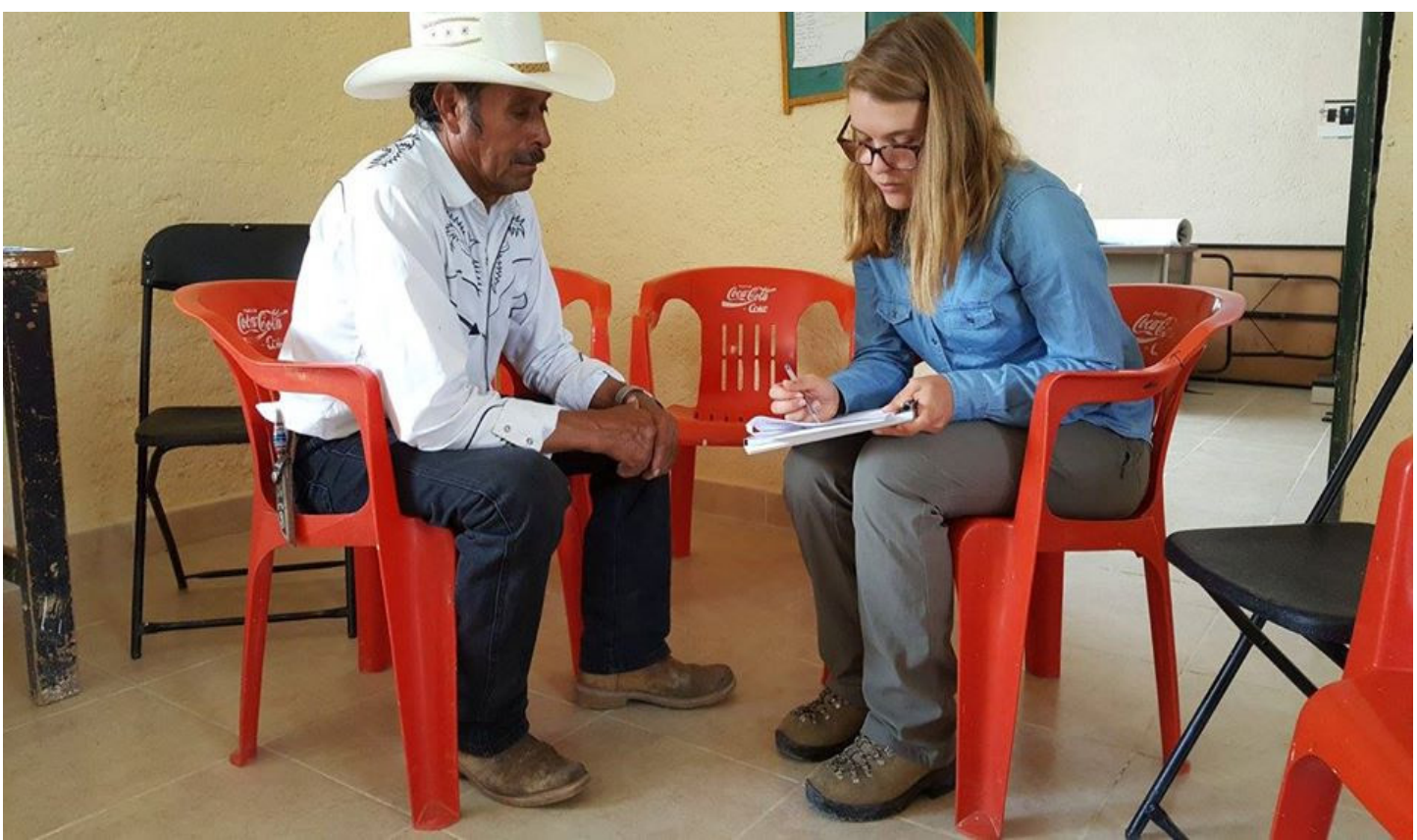

Figure 6.4: Interview collection (photo by Benita Luna - PCMX training director)

Reserve-wide community surveys were conducted by CONBIODES personnel in October 2017 (CONBIODES, A. C., 2017). In Coatepec, the survey was handed out after a day-long training on monitoring neotropical felines where personnel helped community members fill out the questionnaire as needed, community members also discussed answers with one another. Most participants in the surveyed group were local leadership members (bienes comunales and ejido). In May-July of 2019, community interviews were conducted by me with the help of a community partner in Santiago Coatepec, Caltepec, Puebla. I also interviewed the county veterinarian and adjacent community leadership group to give additional points of reference. I collected interviews using a purposive or judgement sampling methodology, where I knew I needed to collect information from people who had their livestock on common land and those who did not (Bernard, 2017). I attempted to capture the community's core 
demographics (age, gender, education level, communal land type etc.) with participant selection. Although capturing the demographics may appear as borrowing from quota sampling methodologies, in this case it more closely aligns with purposive because it could be an explanation for differing responses in the cultural phenomenon I was trying to describe. Furthermore, different from quota sampling, I had no set objective of numbers (quota) per interest group. I used purposive sampling because they are commonly used for intensive case studies. Each interview lasted an average of two hours, Questions ranged from livestock management practices, to perceptions of wild animals, to how community members might act should there be a depredation event (Appendix A.2). Participants had the option to fill out a questionnaire themselves or have me fill out their responses(Figure 6.4). Most opted for the second option, however some members have a sense of pride in their ability to write, so I did not want to take that away from them. In all, I conducted 29 interviews. Interviews were conducted in Spanish and then translated into English. In sum, the interviews represented a qualitative, nonprobability sampling information. Which gives useful information in terms of the variety of cases, rather than in statistical generalizations.

I also collected extensive ethnological data as I lived in the community of Santiago Coatepec over two years. I inductively formed methodologies appropriate for immersive studies such as keeping different types of records, such as audio recordings of public workshops, meeting notes, documentation of conflict mitigation measures taken in the community, written answers to environmental education worksheets, as well as conversations with community members regarding the subject matter at hand (O'reilly, 2012). Ethnographic methods. Routledge.). As a part of my role with the Biosphere Reserve, I helped many other communities conduct biological monitoring and could use my experiences across a wide sample of communities as reference to evaluate what I saw, heard and experienced in Coatepec. For both interview and ethological data, I cleared my research methodologies and study objectives with the International Review Board of Michigan Technological University (Appendix A.1).

\subsection{Analysis}

\subsubsection{Camera Trap Analysis}

This study was a multi-season project focused on multiple species of mammals - both identifiable and non-identifiable. Single cameras were used at camera stations so no spatial capture-recapture (SCR) based analyses could be inferred from these data. Analysis was centered around species identification and detection/non-detection, number of camera triggers, photographic rate, and behavior data measurements. 


\subsubsection{Data Organization}

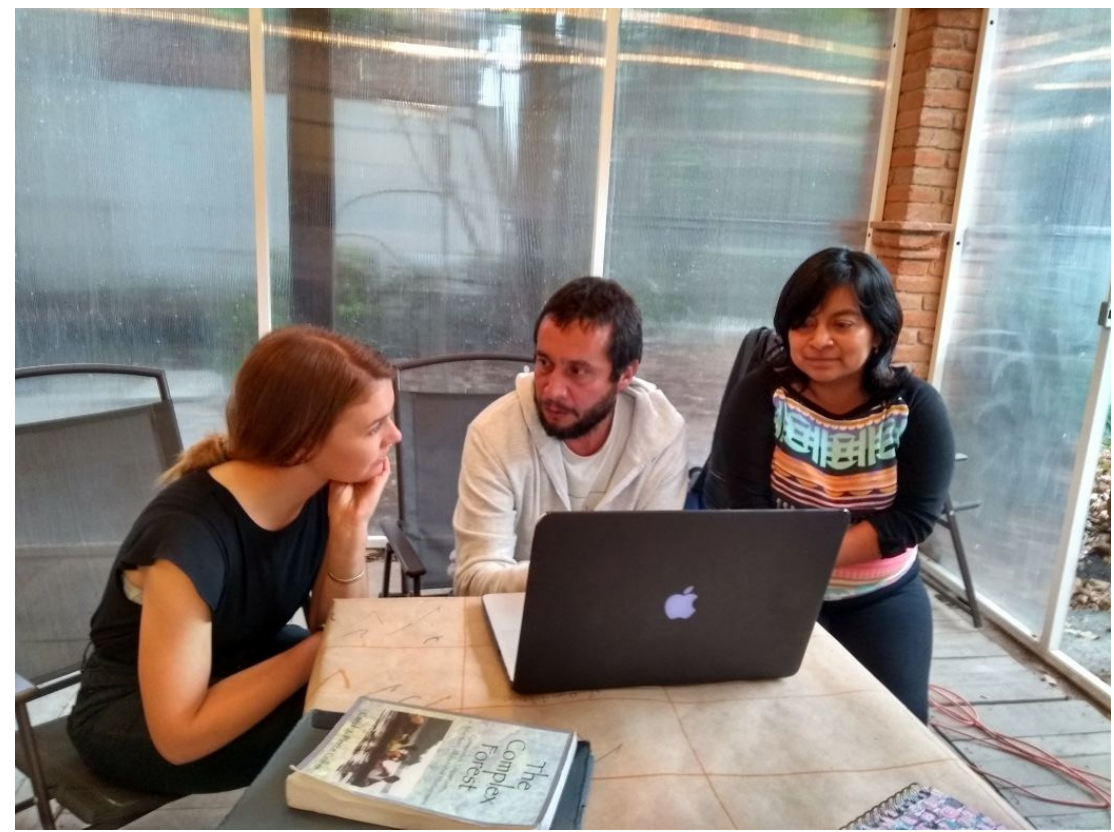

Figure 6.5: learning from a UNAM professor and founder of CONBIODES to design a camera trap study. (Photo courtesy of the author.)

Videos were organized on ADATA 1T hard drives by a folder naming scheme using common land group (Ejido, Bienes Comunales), year (2017-2019) and camera station plus visitation date (Camera\#_Camerastationname_MM-DD-YY) (Figure 6.6). Original archives were left untouched, but videos from each camera station containing mammalian species of interest were copied into folders of the species they represented (Figure 6.6). Species were identified by body form and size within each video, and when possible, sex, age and vital state were also defined with physical identifying features. Each video triggered by domestic animals or wildlife was given a unique individual identification number (DS\#\#\#) and entered in an Excel database with 43 columns containing pertinent covariate information such as: location, altitude, 
vegetation, soil type, date, season, and interactions. A total of 3,376 videos were documented by this means for descriptive analysis.

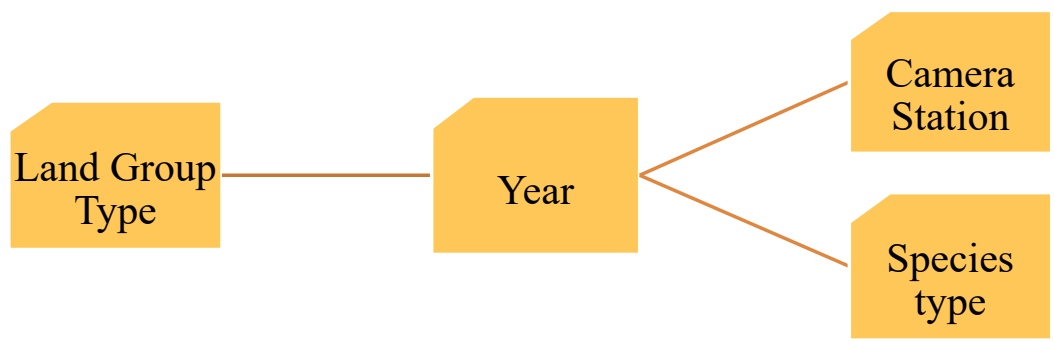

Figure 6.6: Folder system in ADATA 1T hard drive (figure by the author)

Error occurred in the study through batteries dying, false triggers, and lack of detection. The cameras we used had a $0.4-0.7$ second trigger speed and 80-foot detection range. Therefore, lack of detection of some species and over detection of others occurred.

For much of the analysis, I organized and manipulated the data to fit the models in Rstudio. I formatted the Excel database to CSV (Comma Separated Values) to be imported into Rstudio. I used Excel pivot plots as a simple mechanism to visualize data. I utilized the following analyses to give a better understanding of the unique mammalian composition and behavior captured by this study.

\subsubsection{Species Data: Species Diversity and Richness}

Species diversity is measured by the number of species present and their relative abundance. This is useful especially if there is prior information in surrounding areas about the total number of species that could be present. Species diversity was calculated using the Shannon-Wiener Index based on camera trap station and species. I used trigger data with number of individuals per video to determine diversity using the following equation:

$$
\mathrm{H}=\sum[(\mathrm{pi}) \times \ln (\mathrm{pi})]
$$

Pi is the proportion of each species observed in the total sample.

I compared continuous diversity across sites using the Rényi Diversity calculation (Rényi, 1961): 


$$
\mathrm{H}_{\alpha}=\frac{1}{1-\alpha} \log \sum_{i=1}^{S} P i^{\alpha}
$$

Alpha refers to the likelihood that the true population lies outside of the sample population parameter. Under the Rényi entropy using the Shannon index as our input we find the level of diversity as alpha moves toward 1. The resultant graphs can show which sites have overall higher diversity when alpha goes toward infinity.

I plotted species accumulation curves for species richness using cumulative species detected chronologically by camera station to measure species richness in the study area (Ugland, Gray, \& Ellingsen, 2003). In the plotted curve, the proportion is the number of species minus the frequency of the given species over the number of species denoted by the following equation (Oksanen, 2013).

$$
\widehat{S_{n}}=\sum_{i=1}^{S}\left(1-P_{i}\right), \quad \text { where } P_{i}=\frac{\left(\begin{array}{ll}
N- & f_{i} \\
n
\end{array}\right)}{\left(\begin{array}{l}
N \\
n
\end{array}\right)}
$$

\subsubsection{Detection/Non-Detection Data: Distribution, Occupancy and Abundance}

I plotted species using binary data $(0,1)$ to suggest detection or non-detection under certain conditions. Parameters included temporal and spatial covariates: camera station, landform, season, and time of day plotted against species type. The models account for imperfect species detection; just because a species is not detected does not mean that it is not present, as it may have been missed due to low density or insufficient sampling effort (MacKenzie et al., 2002, 2006). To make calculations, I used a multispecies model constrained to single seasons (Rota et al., 2016).

Detection is classified by 1 if species $i$ is detected within the sampling parameters and 0 it is not detected.

$$
w_{i t}= \begin{cases}1 & \text { if detected at site } i \text { in sample } t \\ 0 & \text { if not detected. }\end{cases}
$$

I then analyzed the resulting matrices in Rstudio with chi-squared tests and a heat map. 


\subsubsection{Photographic Rate Data: Index of Activity}

Photographic rates indicate the number of independent captures per sampling effort (camera station within a time period, such as season). Using photographic rates should be viewed not as a way to calculate abundance but as a way to estimate species activity. Calculating abundance in unmarked populations is prone to bias and error because it neglects to account for flawed detection (Palmer et al., 2018). The most common error comes from over detection of common species and under detection of rare or uncommon species. However, photographic rates can still be useful to view what species are present given a set of spatial, temporal, and behavioral factors (Sollmann, Mohamed, Samejima, \& Wilting, 2013).

\subsubsection{Activity Data: Kernel Density}

The camera trap videos recorded all have time stamps and timing can be used to analyze activity patterns across species. I calculated kernel density estimates and plotted the results in Rstudio.

\subsubsection{Ethological Data: Correlations}

Some of the covariates collected from the camera trap videos concerned animal behavior. I made a table outlining the most common behaviors witnessed and information about inter- and intra- species interactions. I also plotted species type against binary interaction data labeled negative, neutral, or NA for no interactions. I used correlation and chi-squared tests and visualized the data with scatter plots in Rstudio to determine if there was any correlation between species and interaction type. Correlations are generally used when dealing with a predictor and a response variable (Gelman \& Hill, 2006).

\subsubsection{Ethnographic Analysis}

\subsubsection{Interview Analysis}

I made a summary Excel table from the findings of the 2017 CONBIODES questionnaire to use for comparison with 2017 data. I transcribed the interviews I collected in 2019 into an Excel database and uploaded them as cases into NVivo. Based on the interview format, NVivo was not wholly useful for answers that were numerical, ranked, or categorical responses. However, several free response questions gave a deeper understanding into the perceptions and actions of Santiago Coatepec regarding human-wildlife conflict (HWC). I classified free response questions into categories for easier analysis. In all, I used combination of Excel and Rstudio to interpret findings from the questionnaire. Rstudio was simply used to visualize responses. Although I 
would have liked to collect more, due to time, location, and cultural restraints (I needed to be accompanied by a local leadership group) I only completed 29 interviews. This could mean that my sample way too small to fully encapsulate the overall community's feelings, thoughts, and actions, however, there under a purposive sampling methodology, one only tries to get as many interviews as possible.

\subsubsection{General Ethnographic Observations}

While living and serving as a volunteer for two years in Santiago Coatepec, I amassed various forms of ethnographic information. These were notes from meetings, recordings from public workshops, observations of certain actions or attitudes and remembrance of comments that were shared to me in private or during monitoring and environmental education events.

To interpret my observational data, I used two recorded conversations, several free form answers from the questionnaire, various actions/occurrences, and beliefs, to describe the community's relationship with biodiversity. I hand-coded observational

data for easier interpretation. I only recorded public meetings where the topic was of interest to my study objectives. I transcribed and translated the conversation into a word document. I coded for feelings and actions pertinent to perceptions of wildlife and livestock management. The free-form response to the questionnaire was originally transcribed into a word document per "case" but then input into an excel document. The free form answers were used to corroborate similarity of feelings and experiences in my community. Actions I observed were recorded in a journal to give reference for my weekly agenda for CONANP, bi-annual report for Peace Corps (VRF), and in semester reports for the Peace Corps Master's International program at Michigan Tech. The analysis was simply observation based to inductively generate relevant further questions to explore. 


\section{Results}

\subsection{Camera Traps}

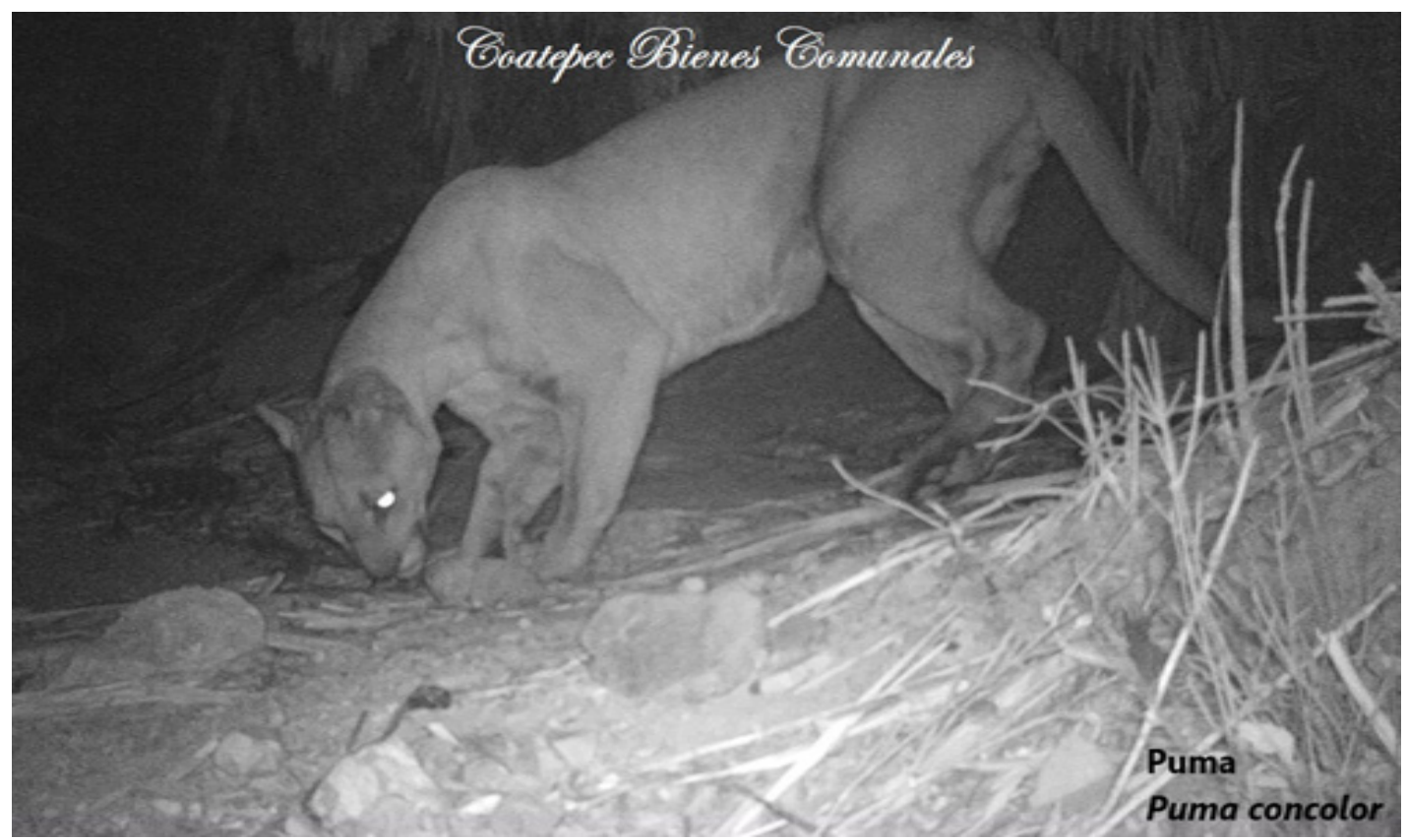

Figure 7.1: Puma (Puma concolor)

The six cameras placed at 18 different stations captured 5238 videos in total (709 wildlife videos and 2360 livestock videos) over a sampling effort of 1650 camera nights (1121 nights of actual footage). Therefore, the expected value of our sampling effort was 1650, but with 1121 nights of information we have a chi-squared statistic of 169.6, under 17 degrees of freedom and a low $p$ value $(p<0.001)$. This means that our actual camera nights of footage do not match up with our expected camera sampling effort (caused by batteries dying etc.). Table 7.1 shows the number of species identified during the study and gives an estimate of percent captures, trapping success (number of detections per sampling effort- actual footage) and captures per sampling effort derived from data of each field site. $41.1 \%$ of footage captured was false triggers, $5 \%$ of footage was of native birds, insects, reptiles, and unidentifiable species, $9.8 \%$ of footage was of native mammals and $52.1 \%$ of videos were of domestic animals and humans. These percentages do not need to add up to $100 \%$ because in many videos there were multiple species present. Trapping success was taken by using the number of captures over the sampling effort per site, therefore results are reported as a range. The number of captures was calculated simply by taking the number of triggers at each camera station of each species. This number is different from the number of independent individuals because it is the calculation of total counts of identifiable 
individuals (species with distinct markings or physical traits) and of unidentifiable (unmarked) individuals separated by a period of 24 hours. This count takes the number of individuals present in each video where the number of captures does not. The independent captures at each camera station was divided by the sampling effort per station. Therefore, one might note higher relative indices for species such as whitetailed deer. This is due to the fact that where they were present, they had high numbers (e.g., traveled as multiple-individual groups) relative to the sampling effort at that location.

Table 7.1: Camera results showing total captures, trapping success and independent captures from 2017-2019.

\begin{tabular}{|c|c|c|c|c|c|c|}
\hline $\begin{array}{l}\text { Common } \\
\text { Name }\end{array}$ & $\begin{array}{l}\text { Scientific } \\
\text { Name }\end{array}$ & $\begin{array}{c}\text { Number of } \\
\text { Captures }\end{array}$ & $\begin{array}{c}\text { Percent of } \\
\text { Total } \\
\text { Mammal } \\
\text { Captures }\end{array}$ & $\begin{array}{c}\text { Trapping } \\
\text { Success by } \\
\text { number of } \\
\text { triggers }\end{array}$ & $\begin{array}{c}\text { Number of } \\
\text { independe } \\
\text { nt } \\
\text { individuals } \\
\quad(24 \mathrm{hr})\end{array}$ & $\begin{array}{c}\text { Independe } \\
\text { nt } \\
\text { Captures } \\
\text { per } \\
\text { Sampling } \\
\text { Effort } \\
\end{array}$ \\
\hline $\begin{array}{c}\text { American } \\
\text { hog-nosed } \\
\text { skunk }\end{array}$ & $\begin{array}{l}\text { Conepatus } \\
\text { leuconotus }\end{array}$ & 31 & $0.9 \%$ & $0-19.6 \%$ & 20 & 0.445 \\
\hline Armadillo & $\begin{array}{c}\text { Dasypus } \\
\text { novemcinctus }\end{array}$ & 2 & $0.1 \%$ & $0-2.7 \%$ & 2 & 0.027 \\
\hline Bobcat & Lynx rufus & 10 & $0.3 \%$ & $0-3.5 \%$ & 9 & 0.058 \\
\hline Chicken & $\begin{array}{c}\text { Gallus } \\
\text { domesticus }\end{array}$ & 2 & $0.1 \%$ & $0-11.8 \%$ & 3 & 0.176 \\
\hline Coati & Nasua narica & 27 & $0.8 \%$ & $0-24.1 \%$ & 34 & 0.304 \\
\hline Cow & Bos taurus & 1011 & $30.8 \%$ & $0-1320.0 \%$ & 255 & 12.359 \\
\hline Coyote & Canis latrans & 36 & $1.1 \%$ & $0-60.0 \%$ & 28 & 2.748 \\
\hline Dog & $\begin{array}{l}\text { Canis lupis } \\
\text { familiaris }\end{array}$ & 143 & $4.4 \%$ & $0-132.6 \%$ & 121 & 3.633 \\
\hline Donkey & $\begin{array}{c}\text { Equus africanus } \\
\text { asinus }\end{array}$ & 897 & $27.3 \%$ & $0-418.6 \%$ & 194 & 5.987 \\
\hline Goats & $\begin{array}{c}\text { Capra aegagrus } \\
\text { hircus }\end{array}$ & 39 & $1.2 \%$ & $0-41.2 \%$ & 293 & 8.478 \\
\hline Grey fox & $\begin{array}{c}\text { Urocyon } \\
\text { cinereoargente } \\
\text { us } \\
\end{array}$ & 233 & $7.1 \%$ & $0-358.8 \%$ & 90 & 1.475 \\
\hline $\begin{array}{c}\text { Grey } \\
\text { squirrel }\end{array}$ & $\begin{array}{c}\text { Sciurus } \\
\text { aureogaster }\end{array}$ & 8 & $0.2 \%$ & $0-17.6 \%$ & 8 & 0.388 \\
\hline $\begin{array}{c}\text { Hooded } \\
\text { skunk }\end{array}$ & $\begin{array}{l}\text { Mephitis } \\
\text { macroura }\end{array}$ & 3 & $0.1 \%$ & $0-1.2 \%$ & 3 & 0.020 \\
\hline Horse & $\begin{array}{c}\text { Equus ferus } \\
\text { caballus }\end{array}$ & 321 & $9.8 \%$ & $0-670.0 \%$ & 142 & 7.108 \\
\hline Human & Homo sapiens & 308 & $9.4 \%$ & $5.4-188.4 \%$ & 141 & 5.856 \\
\hline $\begin{array}{l}\text { Mexican } \\
\text { cottontail } \\
\end{array}$ & $\begin{array}{c}\text { Sylvilagus } \\
\text { cunicularius }\end{array}$ & 72 & $2.2 \%$ & $0-38.9 \%$ & 35 & 0.391 \\
\hline Mule & $\begin{array}{c}\text { E. asinus } \times E . \\
\text { caballus }\end{array}$ & 10 & $0.3 \%$ & $0-40.0 \%$ & 6 & 0.301 \\
\hline Opossum & $\begin{array}{c}\text { Didelphis } \\
\text { virginiana }\end{array}$ & 40 & $1.2 \%$ & $0-229.4 \%$ & 14 & 0.831 \\
\hline Puma & Puma concolor & 7 & $0.2 \%$ & $0-5.4 \%$ & 4 & 0.050 \\
\hline Raccoon & Procyon lotor & 6 & $0.2 \%$ & $0-17.6 \%$ & 6 & 0.191 \\
\hline
\end{tabular}




\begin{tabular}{|c|c|c|c|c|c|c|}
\hline Ringtail & $\begin{array}{c}\text { Bassariscus } \\
\text { astutus }\end{array}$ & 24 & $0.7 \%$ & $0-23.5 \%$ & 14 & 0.366 \\
\hline $\begin{array}{l}\text { Striped } \\
\text { Skunk }\end{array}$ & $\begin{array}{l}\text { Mephitis } \\
\text { mephitis }\end{array}$ & 3 & $0.1 \%$ & $0-6.7 \%$ & 3 & 0.130 \\
\hline $\begin{array}{c}\text { Vampire } \\
\text { Bat }\end{array}$ & $\begin{array}{l}\text { Desmodus } \\
\text { rotundus }\end{array}$ & 15 & $0.5 \%$ & $0-16.3 \%$ & 14 & 0.338 \\
\hline $\begin{array}{c}\text { White- } \\
\text { tailed deer }\end{array}$ & $\begin{array}{l}\text { Odocoileus } \\
\text { virginianus }\end{array}$ & 35 & $1.1 \%$ & $0-30.2 \%$ & 19 & 3.256 \\
\hline $\begin{array}{l}\text { Unidentifi } \\
\text { ed }\end{array}$ & & 6 & & & & \\
\hline Reptiles & & 5 & & & & \\
\hline $\begin{array}{l}\text { Native } \\
\text { Birds }\end{array}$ & & 218 & & & & \\
\hline Insects & & 9 & & & & \\
\hline $\begin{array}{c}\text { False } \\
\text { Triggers }\end{array}$ & & 2154 & & & & \\
\hline $\begin{array}{c}\text { Total } \\
\text { Mammal }\end{array}$ & & 3283 & & & & \\
\hline $\begin{array}{c}\text { Total } \\
\text { Videos }\end{array}$ & & 5237 & & & & \\
\hline
\end{tabular}

\subsubsection{Species Diversity and Richness}

The total number of distinct species detected in the study area is 24 - this includes both native and non-native species of mammals (Table 7.1). Proportions of individuals in the Shannon-Wiener Index equation was calculated by taking the total number of independent captures of each species (based on 24-hour time period) divided by the sampling effort per camera station was. $\mathrm{H}$ for all the species across camera stations is 2.4. Maximum diversity possible for this area is calculated by $\operatorname{Ln}$ (\#species) which leaves us the value 3.18 .

Though there are problems with the Shannon-Wiener index, such as its bias towards number of species rather than proportions, it better portrays rare/uncommon species which is why I chose it over Simpson's Index (Libretexts, 2019). The Shannon-Wiener Index was also calculated per site giving the following results (Table 7.2). According to the index, site "Agua Salada" (Ejido land) and "Joya de Zotole" (Bienes Comunales) have the highest species diversities and "El Rincon" (Ejido land) has by far the lowest species diversity, respectively. I included the site-specific covariates site characterization and common land type $(\mathrm{B}=$ bienes comunales and $\mathrm{E}=\mathrm{ejido})$ for a more complete view of potential underlying factors influencing variation in species richness. For example, the streambed sites may have lower species richness because they are transitory routes (corroborated by the ethnology data in section

Table 7.2: Shannon-Wiener Index by site (Rstudio results).

\begin{tabular}{|c|c|c|c|}
\hline Site name & $\begin{array}{c}\text { Site } \\
\text { Characteristic }\end{array}$ & $\begin{array}{c}\text { Common Land } \\
\text { Type }\end{array}$ & $\begin{array}{c}\text { Whannon } \\
\text { Wiener } \\
\text { Index }\end{array}$ \\
\hline
\end{tabular}




\begin{tabular}{|c|c|c|c|} 
Agua Salada & Hill & $\mathrm{E}$ & 2.14 \\
\hline Joya del Zotole & Hill & BC & 2.08 \\
\hline Tepayo 2 & Upland/River & E & 1.96 \\
\hline Agua del Carrizo & Spring & BC & 1.90 \\
\hline Tepayo & Farmland/River & E & 1.80 \\
\hline Pochote & Farmland/River & E & 1.75 \\
\hline $\begin{array}{c}\text { Puerto Suelo } \\
\text { Pichilingue }\end{array}$ & Hill & BC & 1.73 \\
\hline La Palmonera & Cliff & BC & 1.57 \\
\hline Agua de Guayabito & Streambed & BC & 1.55 \\
\hline Paraje Salvido & Streambed & E & 1.51 \\
\hline Agua El Huizache & Farmland & E & 1.47 \\
\hline $\begin{array}{c}\text { Barranca de Puerto } \\
\text { Suelo }\end{array}$ & Streambed & BC & 1.34 \\
\hline Agua del Higo & Spring & BC & 1.31 \\
\hline El Corral & Farmland & E & 1.30 \\
\hline Pochote 2 & Farmland/River & E & 1.28 \\
\hline $\begin{array}{c}\text { Barranca } \\
\text { Chicozapote }\end{array}$ & Streambed & BC & 1.27 \\
\hline Rincon Danero & Streambed & E & 1.20 \\
\hline El Rincon & Streambed & E & 0.67 \\
\hline
\end{tabular}

Entropy within the Shannon-Wiener Index can be measured with Rényi entropy measurement. The Rényi helps interpret diversity within a sample by showing the likelihood that the sample is within the true population size (or alpha). Alpha is a continuous variable and helped compare camera trap stations. Figure 7.1 shows the Rényi diversity between six randomly chosen camera stations. The higher the lines on the graph represent higher diversities. The more change in the graphs, the less probable it is that the sample adequately matches the true population size. In Figure 7.1 below, one notes the relatively low diversity represented by the "Rincon Danero" camera station versus the relatively high diversity seen in "Agua del Carrizo."Using Table 7.2 covariate information as a reference, one notices that "Rincon Danero" is a streambed (observed transitory behaviors at this site) and Agua del Carrizo is a spring (important water resource during dry months). 


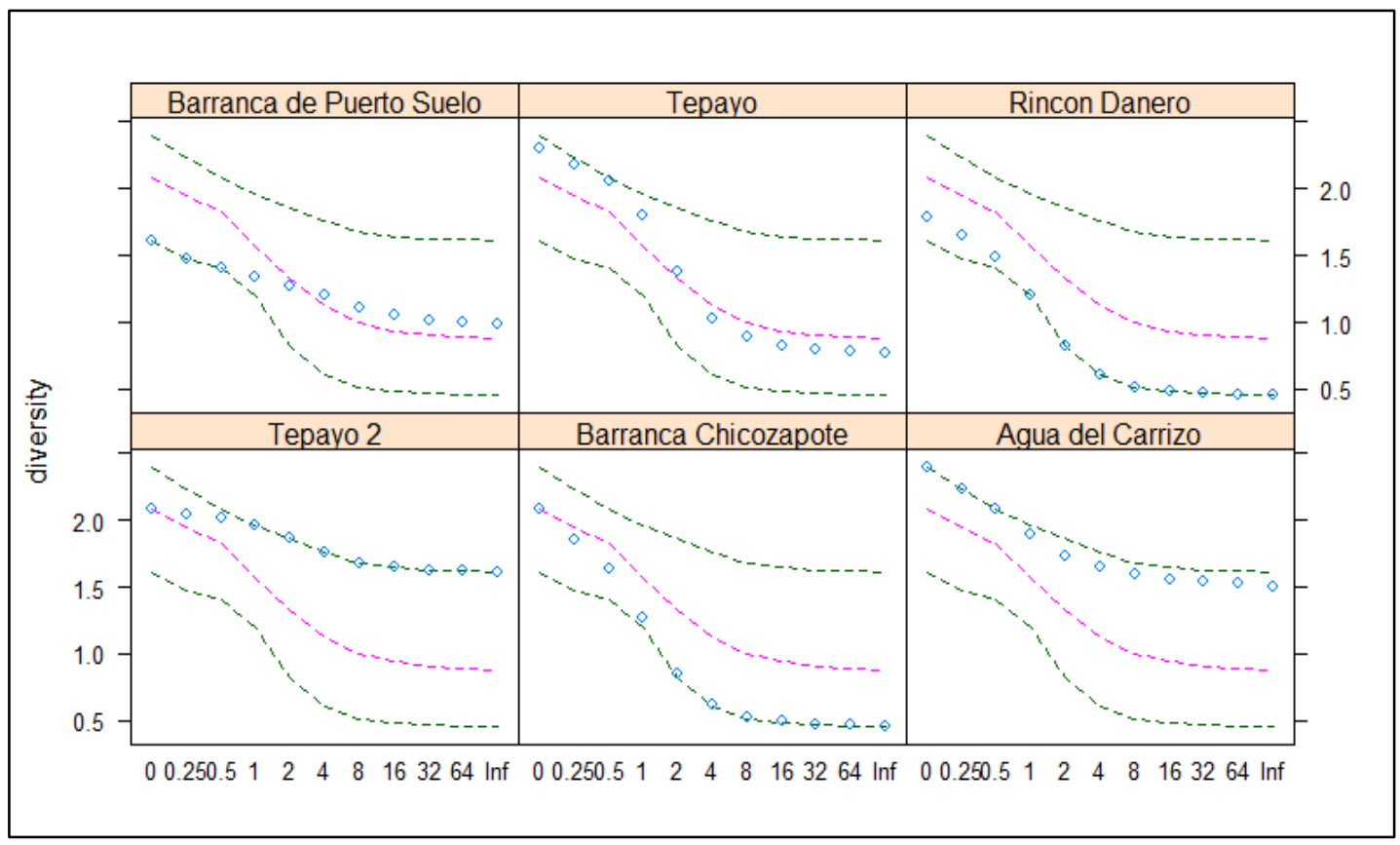

Figure 7.2: Rényi diversities for six randomly selected sites. The hollow blue dots represent the site numbers and the dashed lines represent the maximum, median and minimum values across the randomly selected sites. The $\mathrm{x}$-axis represents the likelihood (alpha) that the sample size is within the true population size as alpha moves from zero to infinity. Overall, the graphs with higher lines have higher biodiversity.

I plotted the number of independent captures per camera station and trapping effort into a species accumulation curve (Kindt's exact method). Figure 7.2 shows the species richness found during the study as number of camera stations increase. The curve in Figure 7.2 shows us how species accumulated in the study with additional study site locations - the maximum values reported are 18 camera stations and 24 native and nonnative species. 


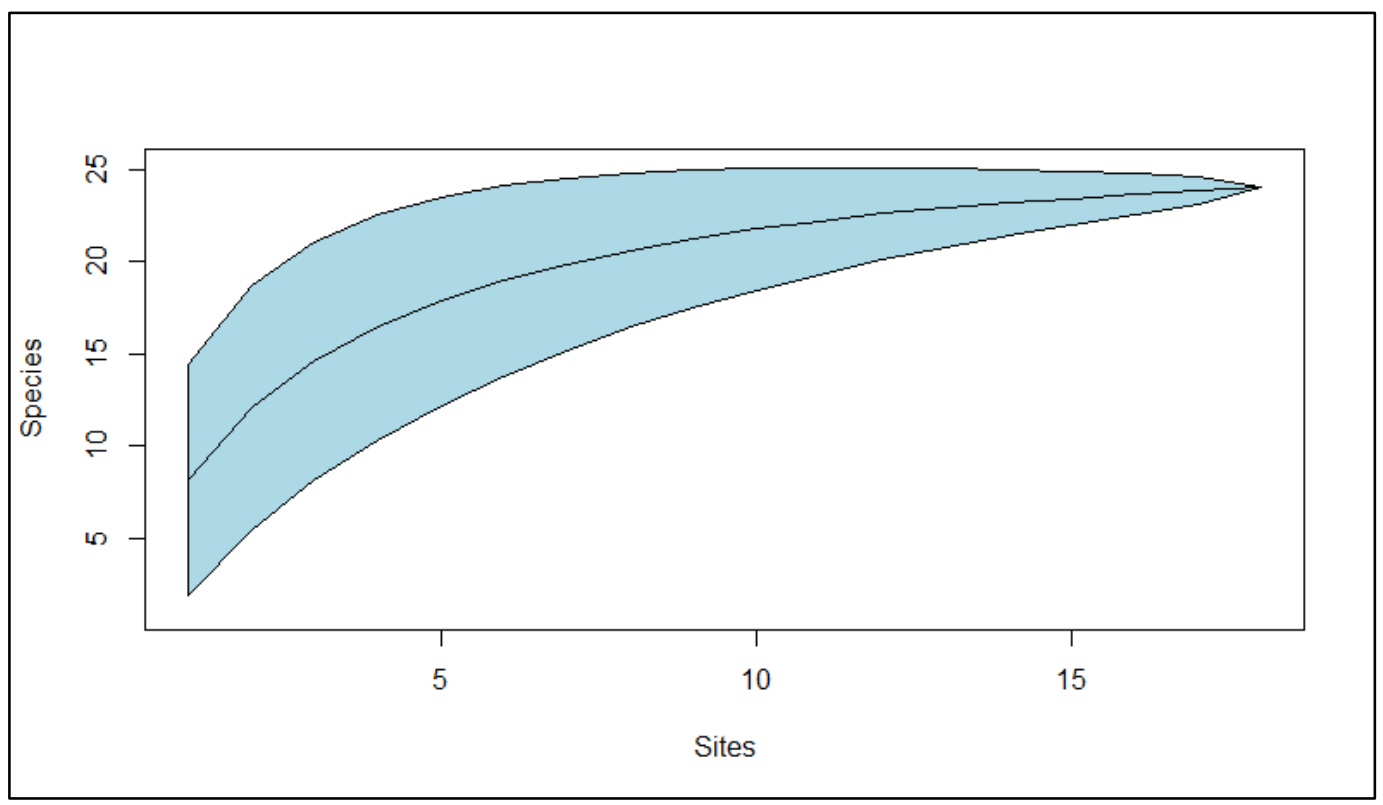

Figure 7.3: Accumulation curve of species over number of sites.

There is a high potential that the study design and sampling effort missed species present in the region and further that models used to interpret results do the same.

\subsubsection{Detection/Non-Detection: Distribution, Occupancy and Abundance}

Detection/non-detection is useful when working with unmarked populations. The overall findings of detection/non-detection show us what is not present in an ecosystem. Multispecies models across multiple sites had to be separated by season. To capture the full dataset, I created a numeric heat map which shows the distribution of species using Dorazio et al.'s (2004) model. For this analysis, I used species captures as a means of species presence. To standardize differing sample effort at some of the camera stations, I found the presence of each species per 100 days by first finding the average daily presence of each species. I ordered both camera stations and species in alphabetical order and gave each a number so that I could plot the heat map of detections by species and camera station. Not all stations were used in both wet and dry seasons, however the number of detectable species stays the same for both Figure 7.4 and 7.5. I used only camera trap stations that were deployed in both wet and dry seasons resulting in a total of 8 camera stations (Figure 7.4 and 7.5).

With this standardization, we can see that wet seasons have a greater number of white spaces indicating less species presence over that time. We can also see that some sites are consistently more diverse that other sites, in both wet and dry seasons, and some (such as site \# 5, or Joya de Zotole) are highly diverse year-round. 


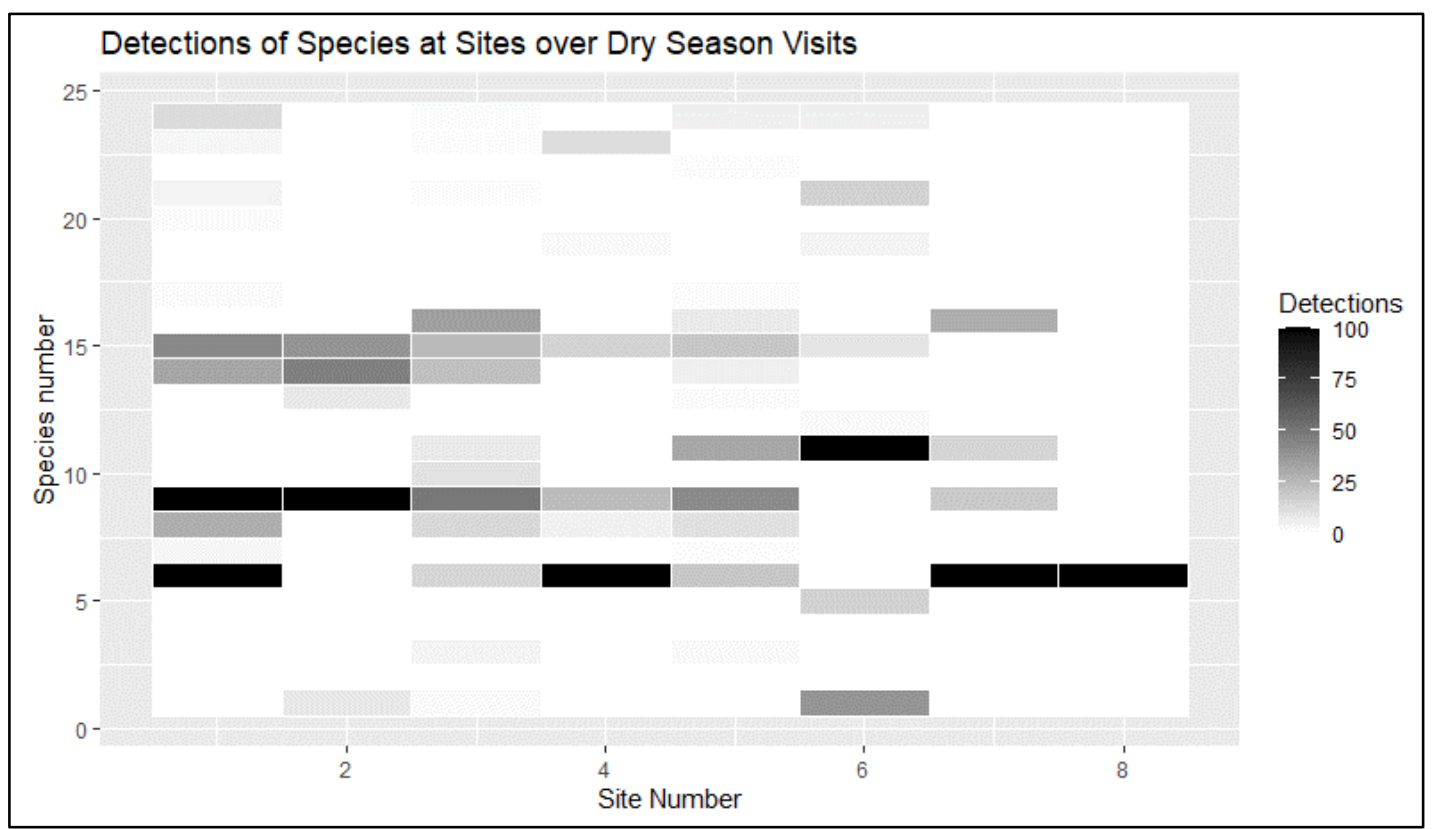

Figure 7.4: Species detection during dry season visits camera visits.

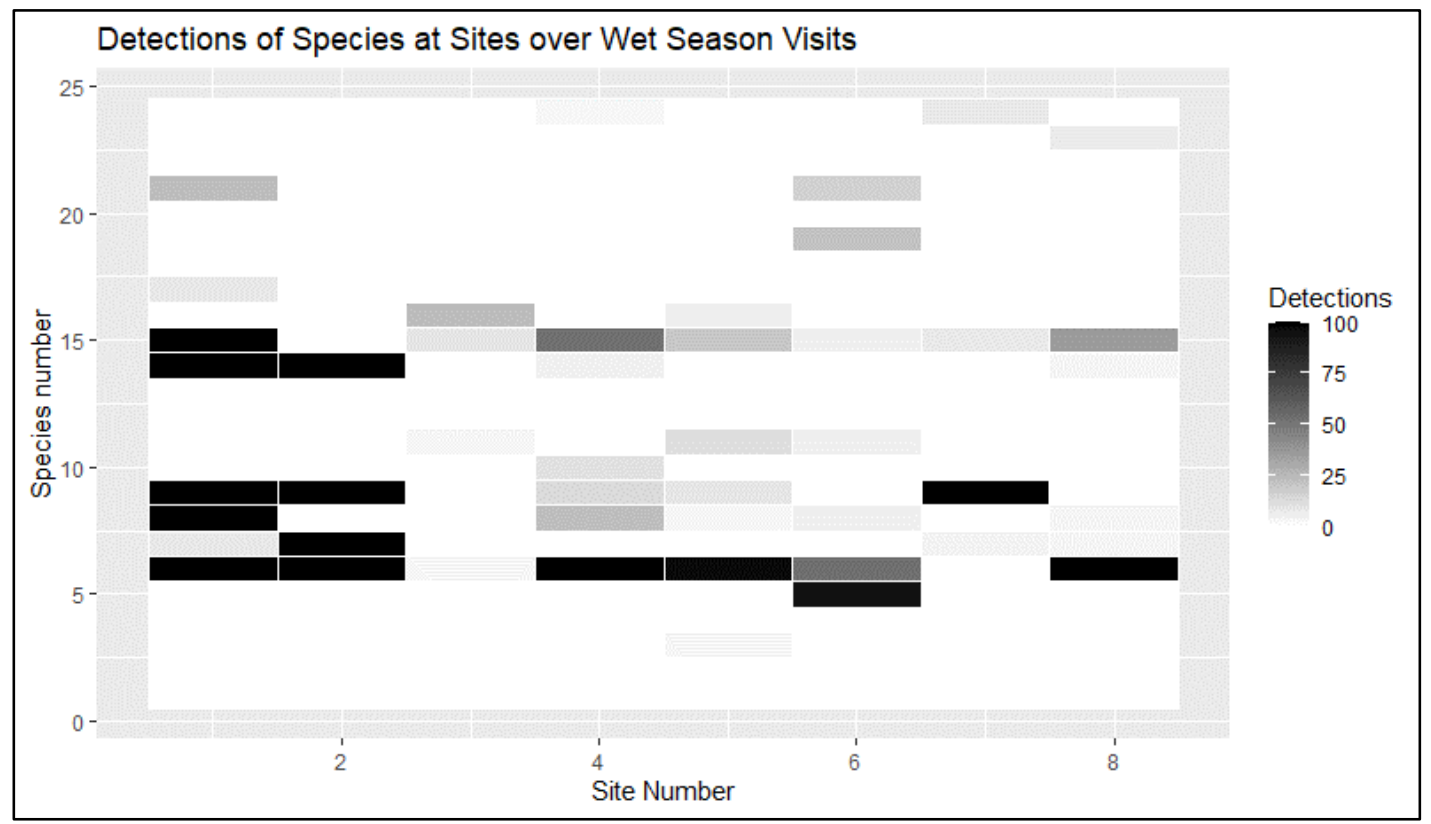

Figure 7.5: Species detection over wet season camera visits. 


\subsubsection{Photographic Rate Data: Index of Activity}

Activity indexes were used by taking the number of independent individuals (24-hour period) by sampling effort for livestock and wildlife on various covariates such as camera station, season, and landform.

A chi-squared test was conducted to examine seasonal differences between species using 100-day site occupancy numbers. Wildlife species per season and camera trap location results in a very large chi square statistic $(\mathrm{X}$-squared $=539.65, \mathrm{df}=15, \mathrm{p}$-value $<.001)$. This signifies that the actual values seen do not match the expected values. For livestock, this statistic is even more exaggerated with a chi-squared value of 937.36 under 7 degrees of freedom (eight domestic species reported) and an even smaller pvalues at $\mathrm{p}<.001$ This shows that we can reject the null hypothesis that there is no difference between seasonal distribution between species, both domestic and wild, supposing we have not made any type I errors. Both livestock and wildlife were observed more consistently during the dry season, however, 29 percent of total livestock observations take place in the wet season and only 10 percent of total wildlife occurrences take place in the wet season. Showing a much more prominent shift in wildlife activity that in livestock activity.

The results from seasonal data represent both temporal distributions. I examined seasonal data on a per-site and per-species basis to give a spatial perspective. To look at distribution between broad animal categories I plotted wild and domestic animals per site based upon sampling effort per 100 days (Figure 7.5). The null hypothesis was that there is no difference between wildlife and livestock in terms of presence per camera trap location. The resulting chi-squared test statistic results in the value 2860.3, under 17 degrees of freedom and a $p$-value $<.001$. This means that the probability that alpha falls to the right of our chi squared statistic is very small. This means that certain sites had far more wildlife observations and activity than others, such as "La Palmonera" and "Joya de Zotole" shown below in Figure 7.5. 


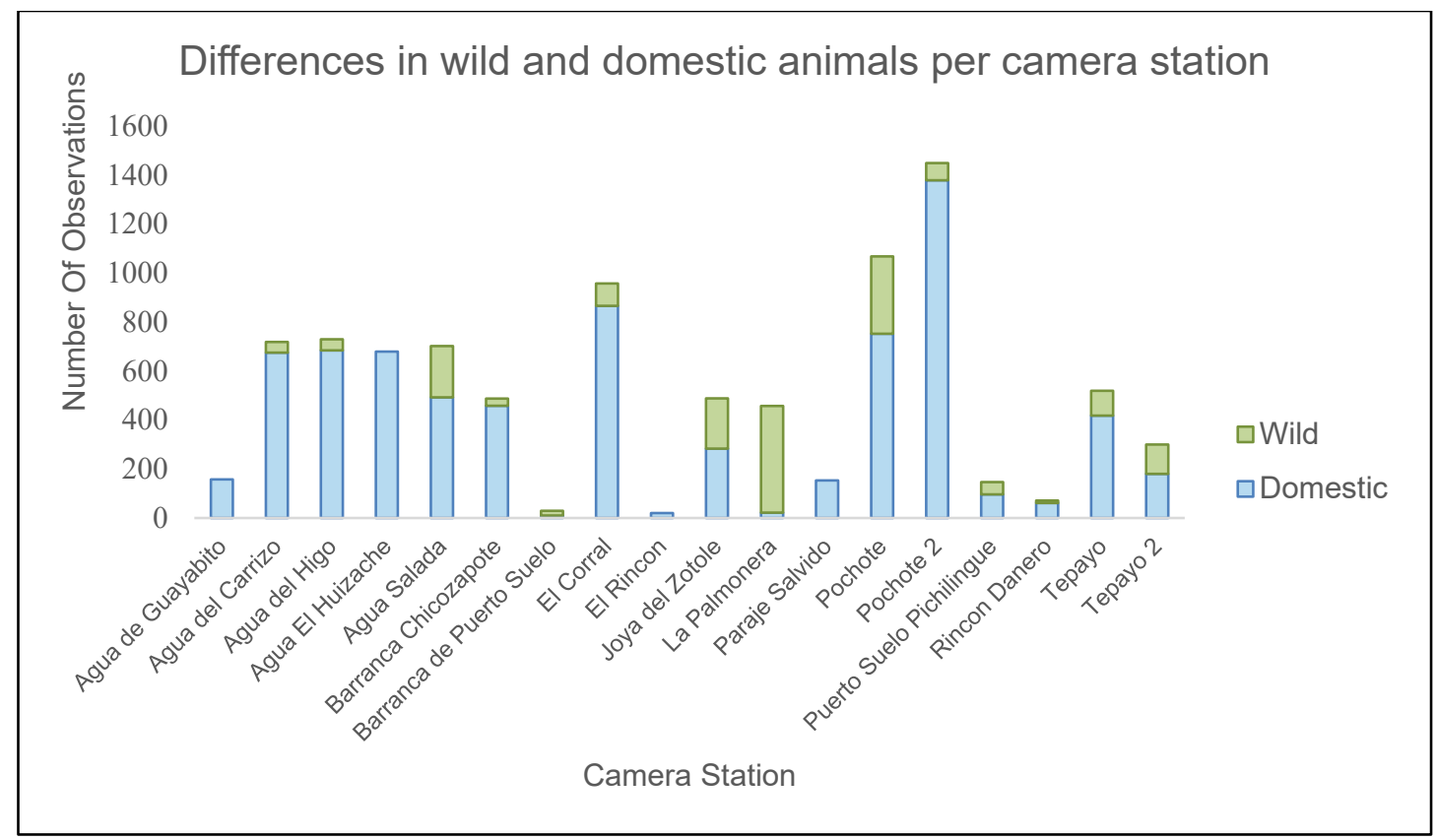

Figure 7.6: Wild versus domestic animal observations at each camera station per 100 camera trap nights.

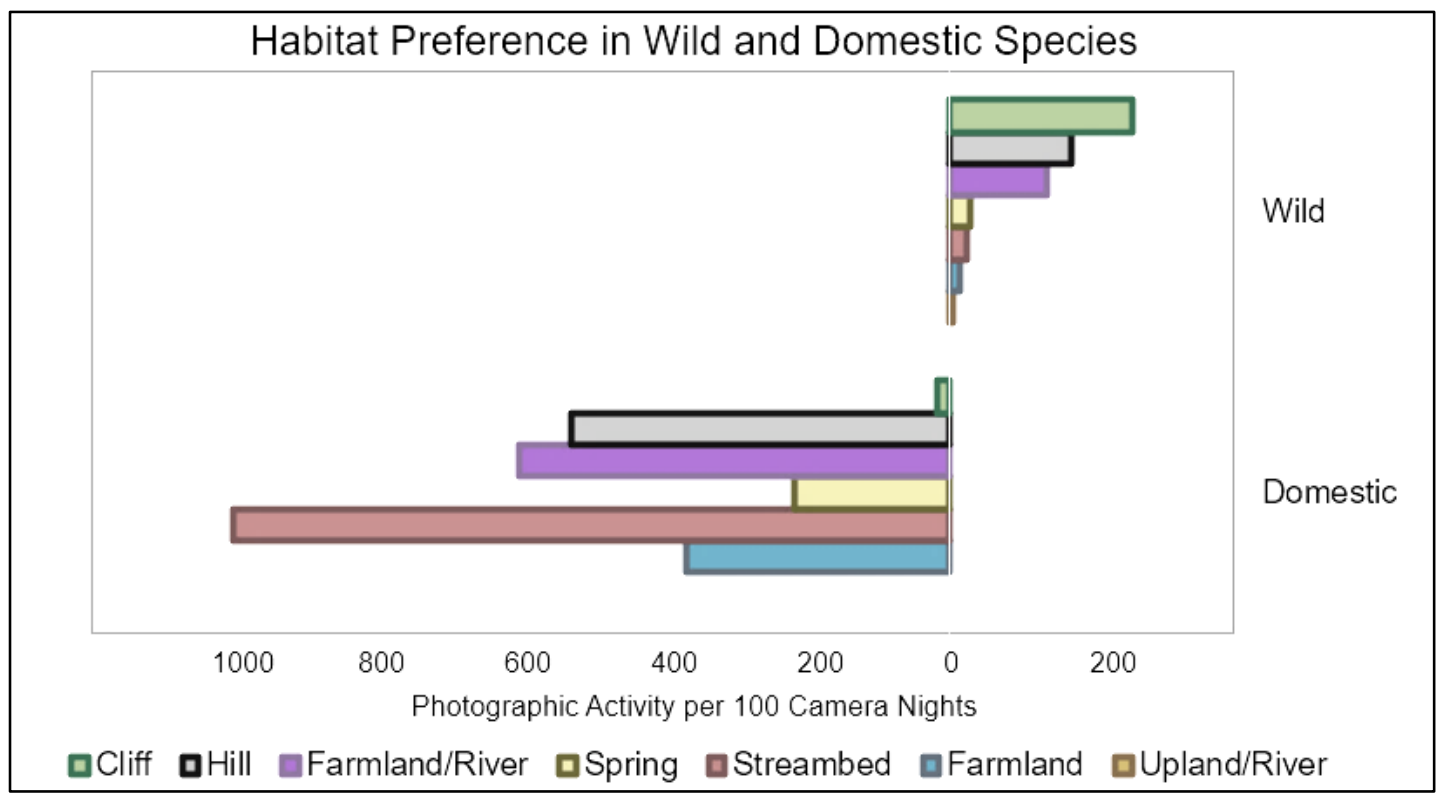

Figure 7.7: Habitat preference between wildlife and livestock. Photographic activity (number of triggers per sampling effort standardized over 100 days) is seen to be different between habitat type and species type.

Camera stations were also described by the habitat they represented. I plotted the independent individuals standardized per camera trapping day over each site 
characterization and found that wildlife occupied a greater number of habitat types than livestock. Where there were hardly any livestock there were higher rates of wildlife present - such as in rugged terrain (cliffs and hills). The chi-squared statistic for site characterization for domestic versus wild animals is 55.793, under 6 degrees of freedom and with a corresponding p-value $<.001$. This seems to tell us that the true values do not match the expected values and the probability that alpha would fall to the right of our chi squared value is very small.

\subsubsection{Activity Data: Kernel Density}

Kernel density estimations can be a useful tool when looking at activity patterns in wildlife and livestock to compare where the highest concentrations occur. Figures 7.8 and 7.9 show that generally, wildlife species have strong peaks during the late night and early morning hours and livestock densities essentially remain the same throughout a 24-hour period. The dashed line represents the mean and the solid line represents the median values, respectively.

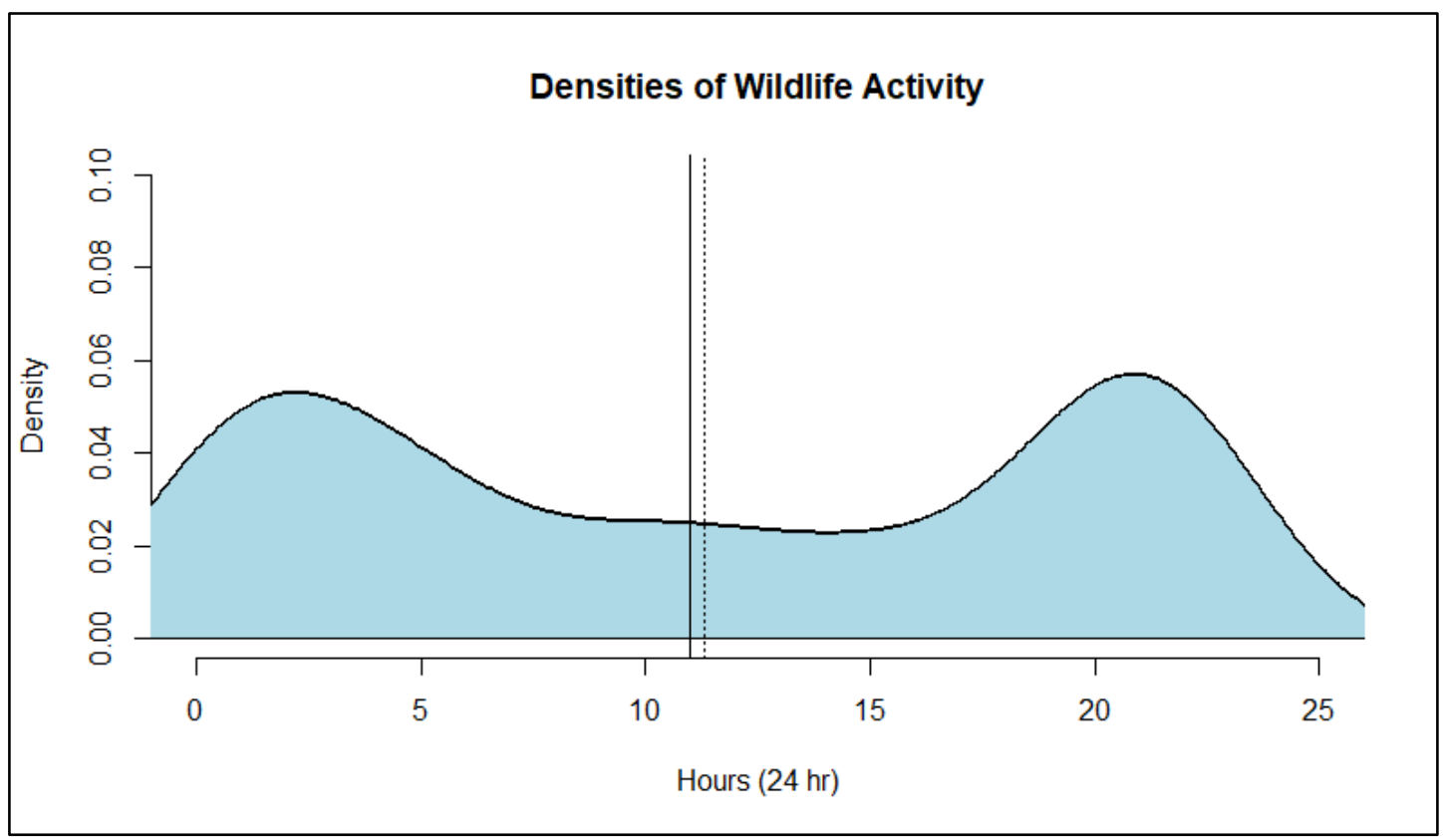

Figure 7.8: Densities of wildlife activity over a 24-hour period. 


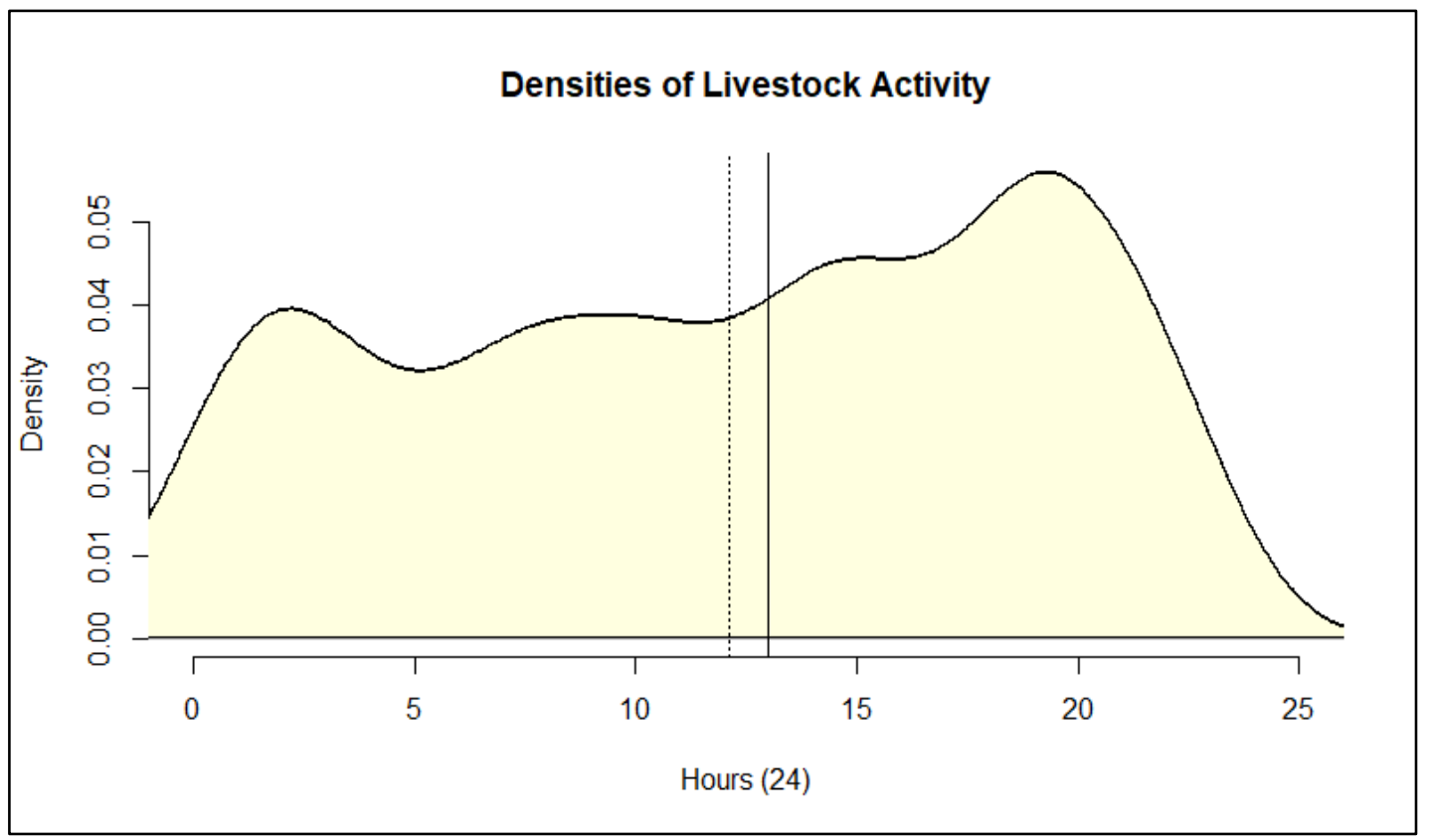

Figure 7.9: Densities of livestock activity over a 24-hour period.

\subsubsection{Ethological Data: Correlations}

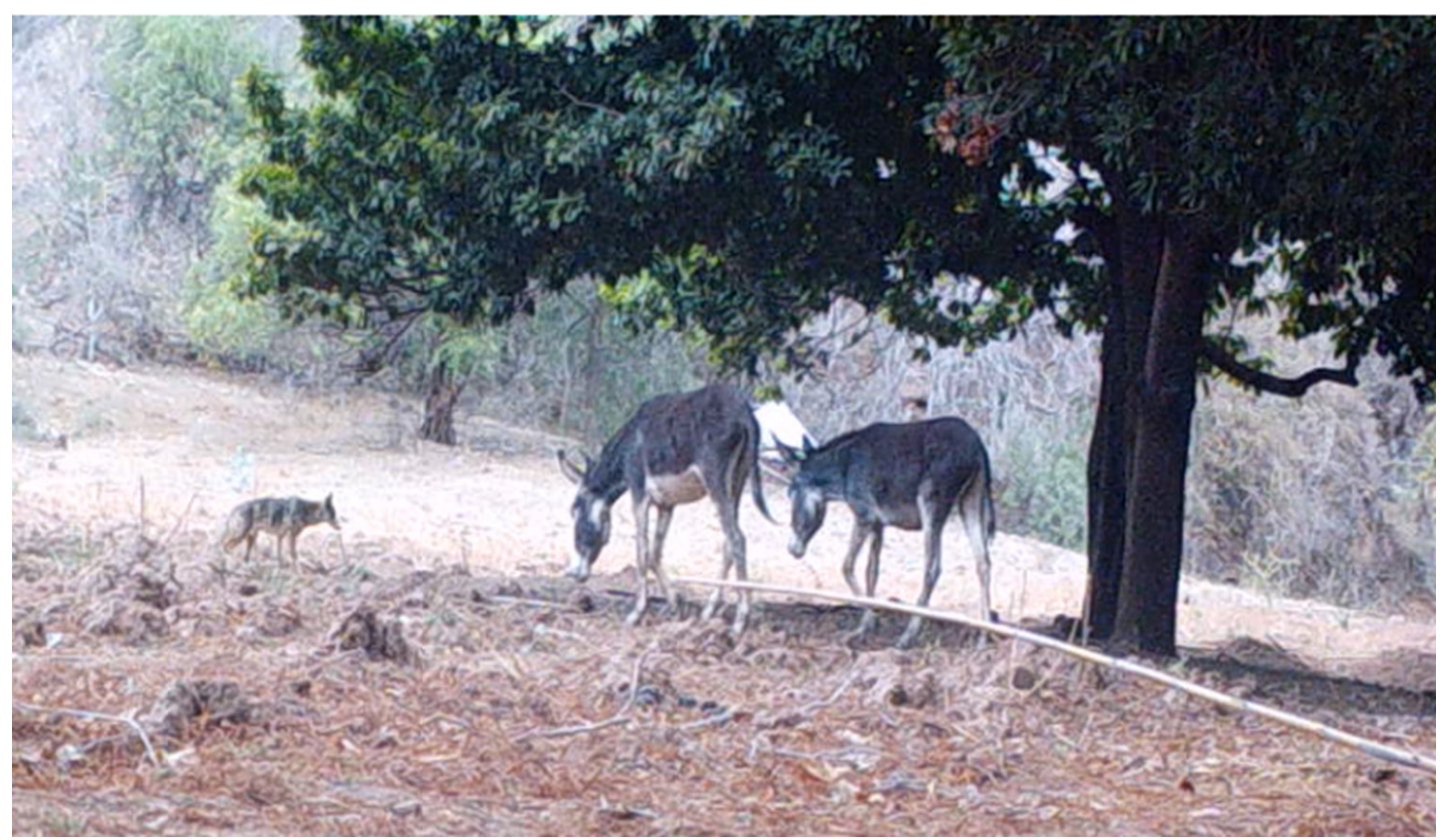

Figure 7.10: Donkeys driving off coyote (camera trap photo)

Ethological data was captured by manually recording animal behavior observed in each video, such as displayed in Figure 7.10. 6049 behavioral data points were captured by 
the camera traps, from which I noted trends in wild and domestic animal observations. I simplified behaviors into broad categories and placed them into Table 7.3 for comparison. Although some videos contained multiple behaviors, the records were simplified to one behavior based upon the overall "objective" observed. The most common behavior for both wildlife and livestock is locomotive behavior (2259 videos). This included any type of purposeful movement from one point to the next. For some species the locomotive behavior was climbing up and down a tree, for others it was flying, and for others it was walking through the camera frame. The least amount of captures was recorded as reproductive behavior, but other categories could contain some of this behavior (territorial behavior, social behavior and investigative behavior). Defensive behavior was noted when species were spooked, but if there was conflict in the video they were categorized under interspecific (or intraspecific) conflict. No direct intraspecific conflict was observed. Foraging behavior was categorized by eating or clearly searching for food. Some videos categorized as locomotive and investigative behavior could include foraging behaviors. Human activities were not limited to just humans but any domestic animals and wildlife involved, for example, all species in a video with a man riding a horse, leading a donkey stacked with wood and followed by dogs would be categorized under the label "human activities". 60 videos were tagged as interspecific conflict - this would be labeled as such for reasons of observed negative interactions such as Figure 7.10. Rest was considered as any long periods of standing and not moving or laying down. Social behavior was videos where any type of neutral physical contact, play, communication, or grooming behaviors were witnessed. Territorial behaviors were any videos were wildlife or livestock were marking their territory. Wildlife observed this category were mainly foxes and pumas.

Table 7.3: Observed behaviors of livestock and wildlife.

\begin{tabular}{|c|c|c|c|}
\hline Behavior Category & Domestic & Wildlife & Total \\
\hline Defensive behavior & 10 & 1 & 11 \\
\hline Foraging behavior & 1206 & 53 & 1259 \\
\hline Human activities & 1225 & 0 & 1225 \\
\hline Interspecific conflict & 47 & 13 & 60 \\
\hline Investigative behavior & 195 & 116 & 311 \\
\hline Locomotive behavior & 1811 & 448 & 2259 \\
\hline Reproductive behavior & 0 & 4 & 4 \\
\hline Rest & 728 & 27 & 755 \\
\hline Social behavior & 118 & 18 & 136 \\
\hline Territorial behavior & 3 & 26 & 29 \\
\hline Total & 5343 & 706 & 6049 \\
\hline
\end{tabular}

Other ethological data collected related to whether there were other species present in the video and if so, if they were domestic or native species. From there, I categorized the species based on the type of interaction (negative or neutral). 
Thirteen species of wild and domestic animals were found to have interspecies interactions. Interactions were categorized as either neutral (0) or negative $(-1)$ depending on what was going on. For example, Figure 7.10 would be classified as a negative interaction where the donkeys were the aggressor. Many videos had multiple species present and to deal with this, each species was given a separate ID and treated as an independent capture in the data base. For easier analysis, the thirteen species were given numerical labels.

When taken by individual species, the correlation found under Pearson's productmoment correlation test was very weak (correlation $<.01$ ), meaning there was no linear relationship between species type and behavior $(\mathrm{t}=0.076186, \mathrm{df}=481, \mathrm{p}$-value $=$ $0.9393)$. This is under the assumption that alternate hypothesis being that correlation between behavior and species type was not equal to 0 under a 95 percent confidence interval (-0.08577466 - 0.09266684) was found using Pearson's product-moment correlation test. However, when tested with domestic (denoted as 1) and wild animals (denoted as 2) versus behavior $(0,-1)$, the test statistic moves to -0.4795118 , meaning that the data is inversely correlated - the variables move away from one another (Figure 7.11). Under a test statistic of $-11.984,481$ degrees of freedom and a p-value $<.001$, there is 95 percent confidence that our value lies between -0.5453998 and 0.4077340 .

\subsection{Ethnographic Results}

\subsubsection{Interview Results}

\subsubsection{2017 Survey Results}

Results of a preliminary group survey conducted by CONBIODES on October $28^{\text {th }}$, 2017 at 4:00 pm reported on several variables relating to animal husbandry practices and wildlife conflict views (CONBIODES, A. C., 2017). The survey was given to the ejido and bienes comunales comisariado group members. The participants identified threats to their local biodiversity as: 1) livestock husbandry as a threat to wildlife and 2) infrastructure (such as houses and roads) as an overall threat to the surrounding habitat. Community leaders surveyed reported that 145 community members were involved in animal husbandry and overall that there were 1413 domestic animals in the community. Participating community members reported equine (horses and donkeys) and ovicaprid (sheep and goats) losses by coyotes, pumas, and other felid species but no losses of livestock by domestic or feral dogs. The summary of results from the CONBIODES 2017 interviews are shown in the table below and are shown with the interview data I collected in 2019. 
Table 7.4: Summary of data collected in CONBIODES group interview in 2017

(CONBIODES, A. C., 2017).

\begin{tabular}{|c|c|c|c|c|c|c|c|c|c|c|}
\hline \multirow{2}{*}{$\begin{array}{l}\text { Agency } \\
\text { applyin } \\
\text { g survey }\end{array}$} & \multirow{2}{*}{$\begin{array}{c}\text { Survey } \\
\text { name } \\
\text { and } \\
\text { year }\end{array}$} & \multirow{2}{*}{$\begin{array}{c}\# \text { of } \\
\text { community } \\
\text { members } \\
\text { practicing } \\
\text { animal } \\
\text { husbandry }\end{array}$} & \multicolumn{4}{|c|}{ Number of Domestic Animals } & \multirow{2}{*}{$\begin{array}{l}\text { Wildlife } \\
\text { Attacks }\end{array}$} & \multirow{2}{*}{$\begin{array}{c}\text { Domesti } \\
\text { c animal } \\
\text { losses to } \\
\text { wildlife }\end{array}$} & \multirow{2}{*}{$\begin{array}{c}\text { Dog } \\
\text { attacks } \\
\text { (feral } \\
\text { or } \\
\text { domest } \\
\text { ic) }\end{array}$} & \multirow{2}{*}{$\begin{array}{c}\text { Biodivers } \\
\text { ity } \\
\text { threats }\end{array}$} \\
\hline & & & $\begin{array}{c}\text { Bovi } \\
\text { ne }\end{array}$ & $\begin{array}{c}\text { Ovica } \\
\text { prid }\end{array}$ & $\begin{array}{c}\text { Poult } \\
\text { ry }\end{array}$ & $\begin{array}{c}\text { Others } \\
\text { (donke } \\
\text { ys, } \\
\text { horses, } \\
\text { mules } \\
\text { and } \\
\text { pigs) }\end{array}$ & & & & \\
\hline $\begin{array}{c}\text { CONBI } \\
\text { ODES }\end{array}$ & 2017 & 145 & 325 & 558 & 410 & 120 & $\begin{array}{c}\text { Coyote, } \\
\text { puma, } \\
\text { other } \\
\text { feline } \\
\text { species }\end{array}$ & $\begin{array}{l}\text { Ovicapri } \\
\mathrm{d} \text {, equine }\end{array}$ & None & $\begin{array}{l}\text { Livestock } \\
\text { husbandry } \\
\text {, } \\
\text { infrastruct } \\
\text { ure }\end{array}$ \\
\hline
\end{tabular}

\subsubsection{Interview data from 2017 and 2019}

I looked at the preliminary 2017 group survey data to see if it was analogous to the interview data I collected after two years of biological monitoring and environmental education programming. I viewed data categories that overlap in order to give my interview data some context. These categories are number of domestic animals, number of community members who practice livestock husbandry, types of livestock lost to depredation, and reported domestic or feral dog attacks. It is important to note however, that since my interview was not a random sample of the community I can only use the 2017 CONBIODES group survey as a means to see if community members reported similarly, or if there were discrepancies in reports between years. In essence, this survey was used to triangulate the 2019 interview results/

Data from the types of livestock is broken down in the table below, however, different survey methodologies make the reported numbers hard to interpret. Therefore, interpretation is limited to triangulation. In the 2017 CONBIODES survey, a general number was reported for each category of domestic livestock - this does not clarify if these numbers are only animals on the communal land or if they also incorporate numbers of animals kept at each household. The survey from 2019 separates the reported numbers of domestic animals present in Santiago Coatepec into three categories: domestic animals on common ejido lands, domestic animals on common bienes comunales land, and domestic animals kept within the fondo legal (urban communal zone - i.e. household). The rationale behind collecting data in three distinct categories is fourfold. First, whether animals kept within the fondo legal is a measure taken by community members to reduce wildlife-livestock conflict, which is reported later in results section 7.2. Second, whether community members surveyed have a good idea of how many animals are on common land and their personal animals. Third, whether comisariado groups kept detailed records of the actual numbers of domestic animals on their common lands. Fourth, if common land types (bienes comunales and ejido) show differing presence of livestock compared to wildlife data; this could show 
correlation between land use and wildlife presence. In the table below, the household data was calculated using the average of domestic animals across the 26 surveys and then multiplied by the number of households in Coatepec. The municipal government reports 166 dwellings in Coatepec, but the president in Coatepec suggested that there are only around 110 households in the community. Therefore, the average of domestic animals per household is multiplied by 110 . No numbers for poultry species are calculated for the bienes comunales and ejido common lands because they were not asked to report on these numbers (poultry is usually kept close to each domicile and is less likely to interact with wildlife near the camera traps). The range and standard deviation of the household numbers are reported in section 7.2.1.3. The number of community members who herd livestock was hard to estimate given the responses of governing groups, and therefore not used to compare but used as a qualitative marker in similarities between responses. On many interviews, community members wrote down "the majority" instead of a numerical answer, indicating that most of their domestic animals were livestock. However, the categorical response of "the majority" does match the shown tendencies of animals per household. The numbers given by the bienes comunales and ejido governing groups are representing the number of people who herd sheep or goats on communal land.

Table 7.5: Domestic animals reported in the 2017 group survey and the 2019 survey.

\begin{tabular}{|c|c|c|c|c|c|c|}
\hline Year & Land type & Bovine & Ovicaprid & Equine & Poultry & $\begin{array}{c}\text { \# of } \\
\text { community } \\
\text { members } \\
\text { who herd } \\
\text { livestock }\end{array}$ \\
\hline 2017 & $\begin{array}{c}\text { General } \\
\text { (CONBIODES) }\end{array}$ & 325 & 558 & 120 & 410 & 145 \\
\hline 2019 & Bienes Comunales & 50 & 80 & 15 & NA & 30 \\
\hline 2019 & Ejido & 80 & 430 & 116 & NA & 60 \\
\hline 2019 & $\begin{array}{l}\text { Fondo Legal } \\
\text { (Household) }\end{array}$ & 89 & 817 & 313 & 597 & NA \\
\hline
\end{tabular}

I used results from the 2017 group survey reporting wildlife attacks on livestock (and species of attacker) to triangulate the data from the 2019 interviews (Table 7.6) In this table only bienes comunales and ejido comisariado results are shown, because the majority of losses stem from communal land zones and they have recorded accounts of each animal loss. However, many animals did not die from wildlife interactions, but rather from disease and drought. The main cause of death was due to paralytic rabies, which is spread through the bite of vampire bats (Desmodus rotundus) common to the 
area and minimally by feral dogs. More general ethnographic results on the loss of domestic animals is given in section 7.2.2. What Table 7.6 also showed me is that community members might not have wanted to tell an outside group what was really going on in terms of numbers of livestock loss and feral dog presence.

Table 7.6: 2017 and 2019 survey results of livestock loss and feral dog presence in Santiago Coatepec.

\begin{tabular}{|c|c|c|c|c|c|c|}
\hline \multirow{2}{*}{ Year } & \multirow{2}{*}{$\begin{array}{c}\text { Reporting } \\
\text { party }\end{array}$} & \multicolumn{2}{|c|}{$\begin{array}{c}\text { Number of domestic animals } \\
\text { lost during respective survey }\end{array}$} & \multirow{2}{*}{$\begin{array}{c}\text { Feral dog } \\
\text { presence? }\end{array}$} & $\begin{array}{c}\text { Problems } \\
\text { generated } \\
\text { by feral } \\
\text { dogs }\end{array}$ \\
\cline { 3 - 7 } & Bovine & Ovicaprid & Equine & & $\mathrm{N}$ \\
\hline 2017 & $\begin{array}{c}\text { General } \\
\text { (CONBIODES) }\end{array}$ & $\mathrm{N}$ & $\mathrm{Y}$ & $\mathrm{Y}$ & $\mathrm{N}$ & $\mathrm{Y}$ \\
\hline 2019 & Ejido & 30 & 100 & 14 & $\mathrm{Y}$ & $\mathrm{Y}$ \\
\hline
\end{tabular}

\subsubsection{2019 Survey Results}

The main purpose of the surveys conducted in May-June 2019 was to capture community perceptions surrounding wildlife and livestock dynamics (the full questionnaire can be found in Appendix A of this document). Questionnaire results are reported by question order and are depicted with graphs and tables developed in Excel and Rstudio. 
The first set of questions regarded demographics. While using a snowball sampling methodology, I tried to evenly distribute the survey to represent underlying demographics (age, gender, education level, communal land type etc.). The table below shows the breakdown of the surveyed members (Figure 7.3).

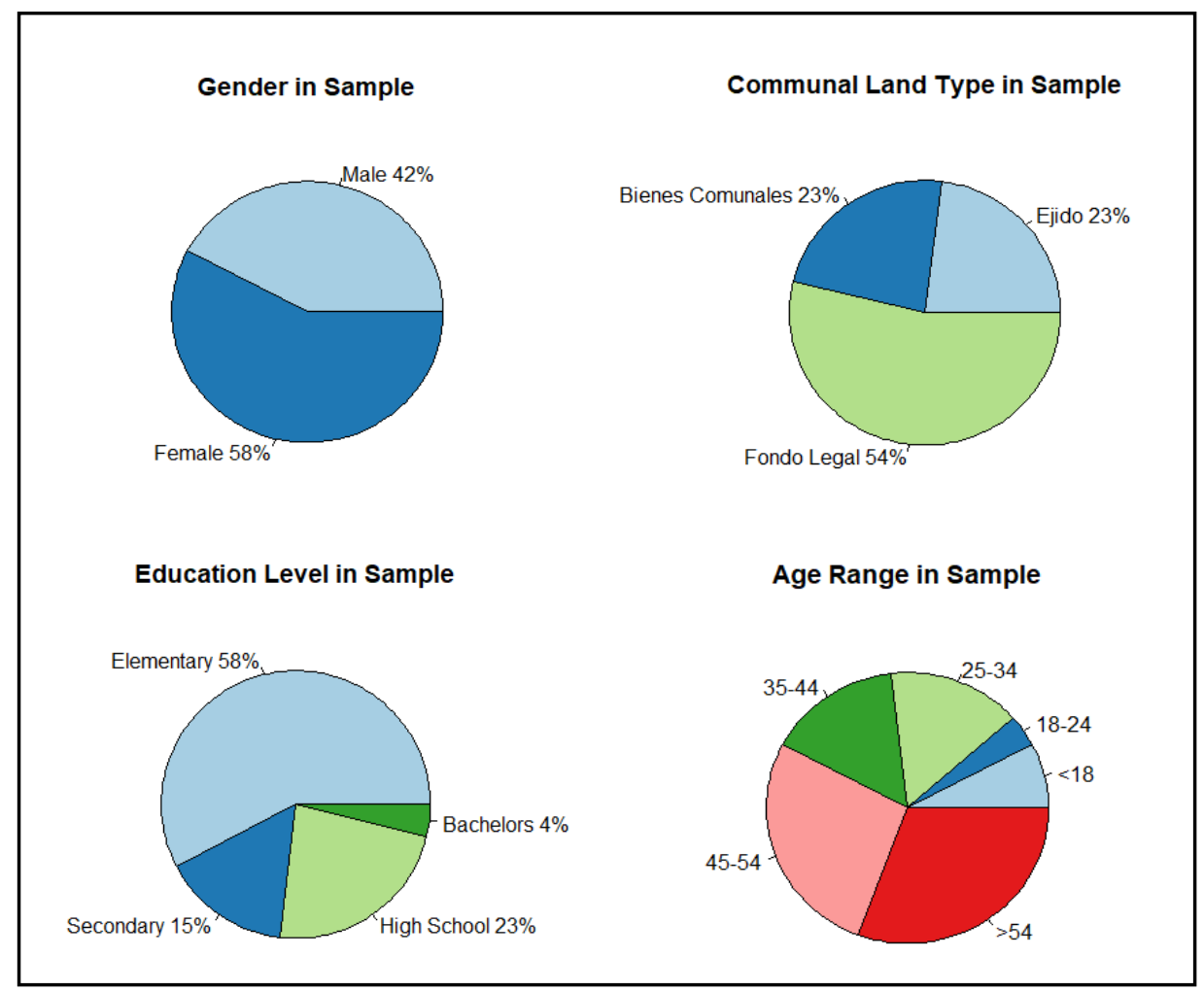

Figure 7.11: Demographics of 2019 Study

The majority of the members of the community who participated in the questionnaire were women, were not part of a communal land system, had completed some elementary school, and were 55+ years old. Not shown as part of these graphics is that the majority of participants did not participate in the wage economy and either worked in domestically or in the fields ("campo") towards subsistence agriculture. The members reporting "agriculture" as their line of work are reported as wage labor, usually selling dragon fruit or avocados. Detailed demographic information is shown below.

Table 7.7: 2019 Survey Demographics

\begin{tabular}{|l|l|l|l|l|l|l|l|}
\hline $\begin{array}{c}\text { Surve } \\
\text { y Data }\end{array}$ & $\begin{array}{c}\text { Communal } \\
\text { landowner }\end{array}$ & $\begin{array}{c}\text { Age } \\
\text { Range }\end{array}$ & Gender & School & $\begin{array}{c}\text { Marital } \\
\text { Status }\end{array}$ & Line of work & $\begin{array}{c}\text { Labor } \\
\text { type }\end{array}$ \\
\hline Case 1 & E & $45-54$ & $\mathrm{M}$ & Elementary & Civil Union & Field worker & $\begin{array}{l}\text { Non- } \\
\text { wage }\end{array}$ \\
\hline Case 2 & FL & $25-34$ & M & High School & Single & Livestock & Wage \\
\hline Case 3 & FL & $25-34$ & F & Bachelors & Single & Administration & Wage \\
\hline
\end{tabular}




\begin{tabular}{|c|c|c|c|c|c|c|c|}
\hline Case 4 & $\mathrm{E}$ & $18-24$ & $\mathrm{~F}$ & High School & Single & Domestic work & $\begin{array}{l}\text { Non- } \\
\text { wage }\end{array}$ \\
\hline Case 5 & $\mathrm{E}$ & $35-44$ & $\mathrm{~F}$ & High School & Married & $\begin{array}{l}\text { Domestic work, } \\
\text { health voluteer }\end{array}$ & $\begin{array}{l}\text { Non- } \\
\text { wage }\end{array}$ \\
\hline Case 6 & FL & $35-44$ & $\mathrm{~F}$ & Elementary & Divorced & Domestic worker & $\begin{array}{l}\text { Non- } \\
\text { wage }\end{array}$ \\
\hline Case 7 & $\mathrm{E}$ & $35-44$ & $\mathrm{~F}$ & Elementary & Single & $\begin{array}{l}\text { Domestic worker, } \\
\text { Livestock }\end{array}$ & Wage \\
\hline Case 8 & $\mathrm{BC}$ & $>54$ & $\mathrm{~F}$ & Elementary & Married & Domestic Work & $\begin{array}{l}\text { Non- } \\
\text { wage }\end{array}$ \\
\hline Case 9 & FL & $45-54$ & $\mathrm{~F}$ & Elementary & Married & Domestic Work & $\begin{array}{l}\text { Non- } \\
\text { wage }\end{array}$ \\
\hline Case 10 & FL & $25-34$ & M & Secondary & Single & $\begin{array}{l}\text { Field worker, } \\
\text { agriculture }\end{array}$ & Wage \\
\hline Case 11 & FL & $25-34$ & M & High School & Single & $\begin{array}{l}\text { Field worker, } \\
\text { agriculture, food } \\
\text { vendor }\end{array}$ & Wage \\
\hline Case 12 & FL & $35-44$ & $\mathrm{~F}$ & Secondary & Married & Domestic worker & $\begin{array}{l}\text { Non- } \\
\text { wage }\end{array}$ \\
\hline Case 13 & FL & $>55$ & $\mathrm{~F}$ & Elementary & Single & Field worker & $\begin{array}{l}\text { Non- } \\
\text { wage }\end{array}$ \\
\hline Case 14 & FL & $45-54$ & M & Secondary & Married & $\begin{array}{l}\text { Field worker, } \\
\text { agriculture }\end{array}$ & Wage \\
\hline Case 15 & $\mathrm{BC}$ & $>54$ & M & Elementary & Married & $\begin{array}{l}\text { Field worker, } \\
\text { agriculture }\end{array}$ & Wage \\
\hline Case 16 & FL & $45-54$ & $\mathrm{~F}$ & Elementary & Married & $\begin{array}{l}\text { Domestic worker, } \\
\text { embroidery }\end{array}$ & Wage \\
\hline Case 17 & $\mathrm{BC}$ & $>54$ & M & Elementary & Single & Field worker & $\begin{array}{l}\text { Non- } \\
\text { wage }\end{array}$ \\
\hline Case 18 & FL & $45-54$ & $\mathrm{~F}$ & Elementary & Married & $\begin{array}{l}\text { Domestic worker. } \\
\text { Embroidery }\end{array}$ & Wage \\
\hline Case 19 & $\mathrm{FL}$ & $45-54$ & $\mathrm{~F}$ & Secondary & Married & $\begin{array}{l}\text { DICONSA } \\
\text { (Community store) }\end{array}$ & Wage \\
\hline $\mathrm{BC} 1$ & $\mathrm{BC}$ & $>54$ & M & Elementary & Married & $\begin{array}{l}\text { Field worker, } \\
\text { construction }\end{array}$ & Wage \\
\hline $\mathrm{BC} 2$ & $\mathrm{BC}$ & $>54$ & $\mathrm{~F}$ & Elementary & Widowed & $\begin{array}{l}\text { Domestic labor, } \\
\text { agriculture }\end{array}$ & Wage \\
\hline $\mathrm{BC} 3$ & $\mathrm{BC}$ & $>54$ & $\mathrm{~F}$ & Elementary & Single & Domestic labor & $\begin{array}{l}\text { Non- } \\
\text { wage }\end{array}$ \\
\hline E1 & $\mathrm{E}$ & $45-54$ & M & Elementary & Widowed & Field worker & $\begin{array}{l}\text { Non- } \\
\text { wage }\end{array}$ \\
\hline E2 & $\mathrm{E}$ & $>54$ & M & Elementary & Married & Field worker & $\begin{array}{l}\text { Non- } \\
\text { wage }\end{array}$ \\
\hline FL1 & FL & $<18$ & $\mathrm{~F}$ & High School & Single & Study & $\begin{array}{l}\text { Non- } \\
\text { wage }\end{array}$ \\
\hline FL2 & FL & $18-24$ & M & High School & Single & Study & $\begin{array}{l}\text { Non- } \\
\text { wage }\end{array}$ \\
\hline
\end{tabular}

The next block of questions asks about livestock and domestic animal practices. All participating community members owned domestic animals. Box plot 7.13 shows the maximum and minimum number of domestic animals per household (whiskers), the median value (demarcated by the horizontal line in each box), the interquartile range (box), and the extreme outlier value (circle). The mean values of domestic animals in each household is roughly: one cow or less; seven goats or sheep; three horses, mules, or donkeys; five chickens, turkeys, or ducks; one cat; and two dogs. 


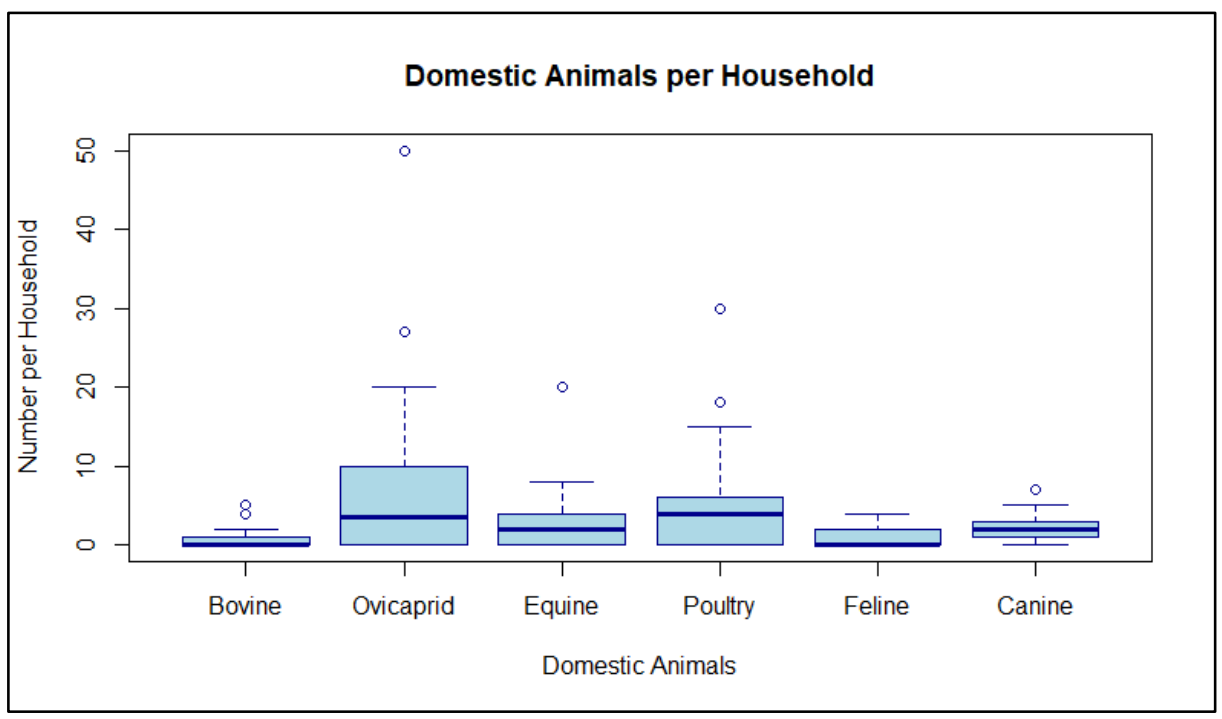

Figure 7.12: Domestic animals per household in Coatepec 2019.

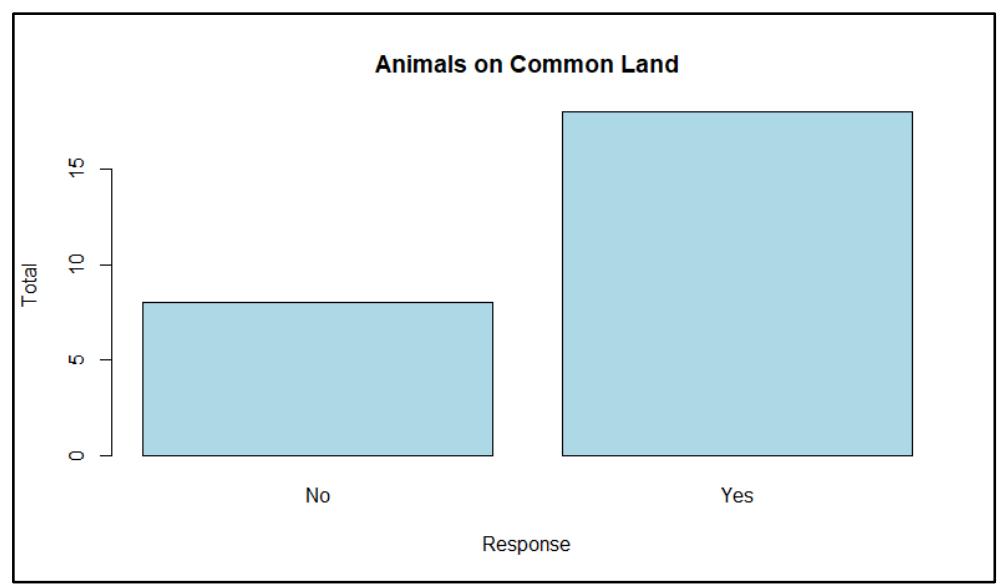

Figure 7.13: Number of community members who have animals on communal land.

There are over twice as many respondents who use communal land for their personal domestic animal use (18) as opposed to those who do not (8). The graph above only shows respondents who let their animals have free range on communal land; it excludes the community members who use the land to graze their animals every day but keep their animals at home - namely those who own sheep or goats. The survey sample failed to capture this portion of the population. That being said, there were some respondents who both had animals on common land and at their home, but instead of buying feed, would take their domestic animals out every day to graze on common land such as Case 7 (Table 7.7). Animals are grazed on common lands because it vastly reduces the price of animal feed and maintenance. Those that reported feeding animals at home had monthly costs of 480 to 5000 pesos ( 25 to $250 \mathrm{USD} / \mathrm{month}$ ) to buy the 
feed alone. For a community where much of the population does not participate in wage labor, this is an exorbitant amount, especially given the price of what they can get for an animal when they sell at market price. Depending on the animal, market price can be anywhere from 200 pesos (chicken) to 12,000 pesos (cow) (10-600 USD). Keeping animals on communal land only costs 80 pesos per year (4 USD). Additionally, there is the cost of vaccinations, medicine and veterinary visits. While vet clinics will periodically visit the community and perform vaccinations and other necessary functions free of charge, if an animal becomes sick, many people do not have the means to pay for medicine. Some people reported spending 150 pesos (8 USD) if they must buy the vaccines themselves. Although the governing groups reported vaccines occurring twice a year, half of the people surveyed reported a number other than twice a year. In fact, the county veterinarian confirmed that vaccines are given twice a year (in October and February) and that the paralytic rabies 79 costs pesos/head and the gangrene vaccine costs 74 pesos/head (totaling 8 USD). There does not seem to be a correlation between land type (fondo legal, bienes comunales or ejido) and response to number of vaccines given per year.

The next block of questions was used to assess perceptions of wildlife and community threats. Questions ranged from the presence and impact of feral dogs, animals considered dangerous to the community and a test of knowledge surrounding wildlife present in the community as well as response of community members to livestock loss by wildlife.

Six of the 26 respondents reported feral dogs present in the community and reported damages. Video evidence shows dogs in the middle of the night without human companions. The county veterinarian also reports deaths by feral dogs during the 20182019 year. Therefore, perhaps the community members are either unaware of their presence or did not answer truthfully about what they knew.

18 out of the 26 respondents listed one or more wild animal as a threat to the community: 4 listed domestic animals (bulls or dogs), one person listed both wild animals and domestic animals, and three people listed no threats (Figure 7.7). The breakdown of these answers is listed by the common name of the animal in the figure below. Community members were most fearful of coyotes, snakes and pumas. The label "Other" simply was used for a response that said, "wild animals". 


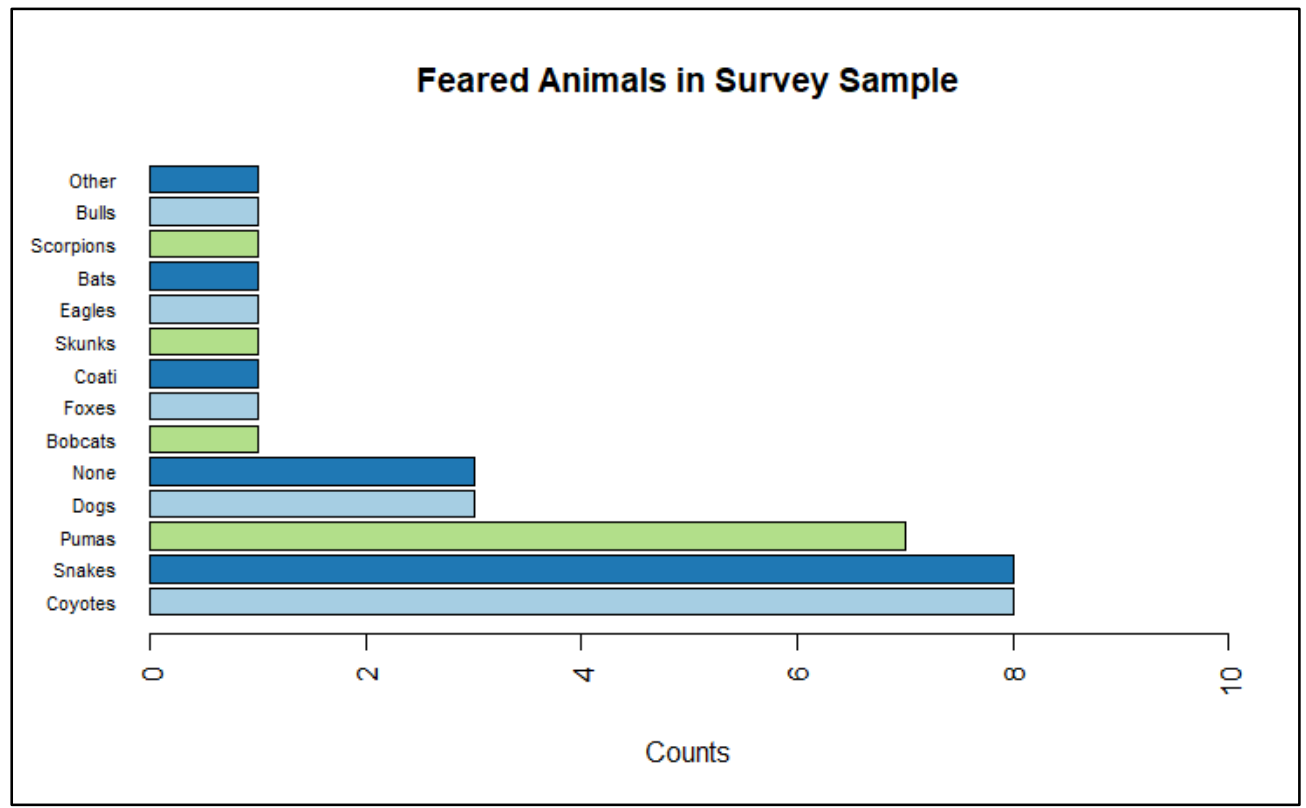

Figure 7.14: Perceived threat of animals in Coatepec.

When asked which native animal was most valued by community members, all except three respondents listed at least one wild animal, one listed a domestic animal, one person listed none, and one person did not know of any (Figure 7.15). Of these responses, 6 community members valued a native predator (puma, eagle, jaguar, anaconda), while 16 valued a prey species (white-tailed deer, desert hare, pecari, chachalaca, armadillo). 17 responses listed deer as a most valued wildlife species.

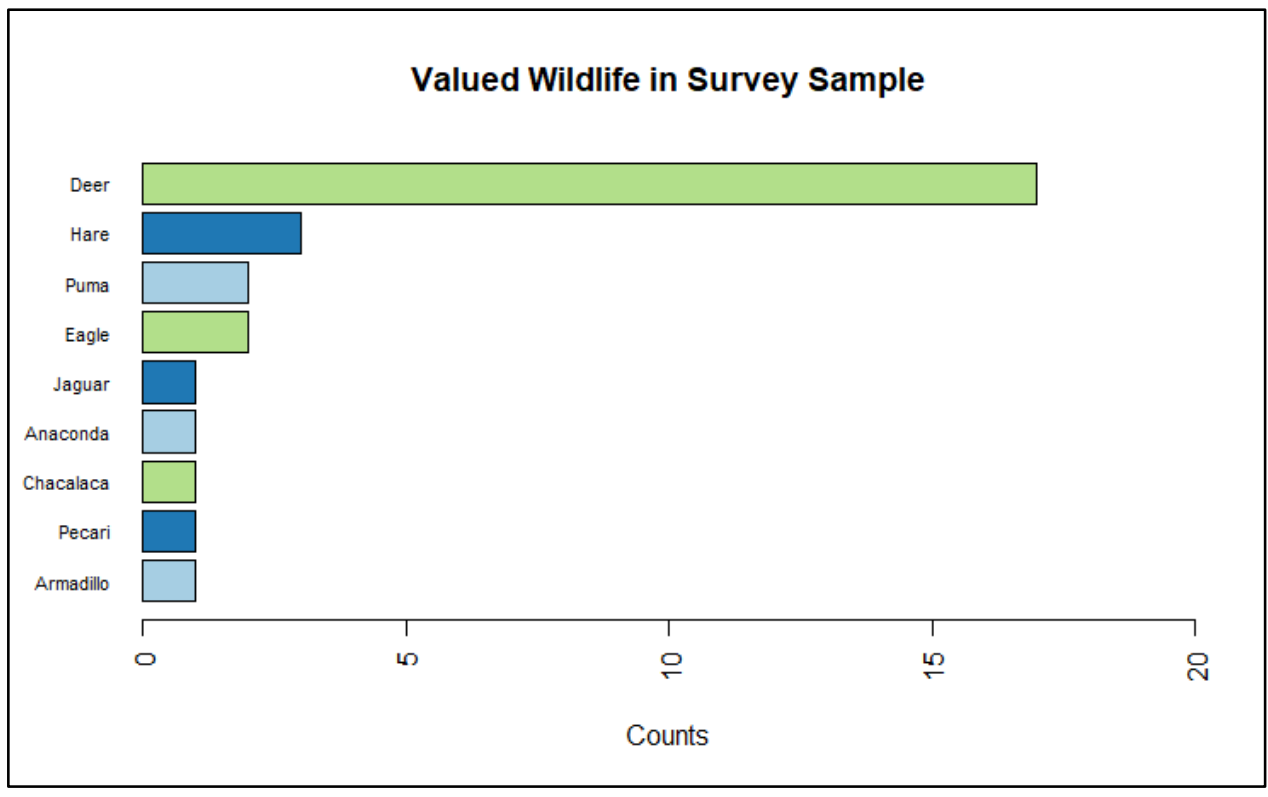

Figure 7.15: Showing the wildlife that community members valued. 
The next question had to do with the community response when livestock is lost to a depredation event. The response was open answer and each answer was given a category of response. Responses ranged from retaliatory (3) to preventative (6). 36\% responded that no action should be taken as a result of wildlife conflict $(n=9)$. Some of the responses were hard to classify because they could fit into two categories, such as a person reporting a depredation event to the local authorities - this could be so that they organize a retaliatory effort or it could be to mitigate losses (Table 7.5).

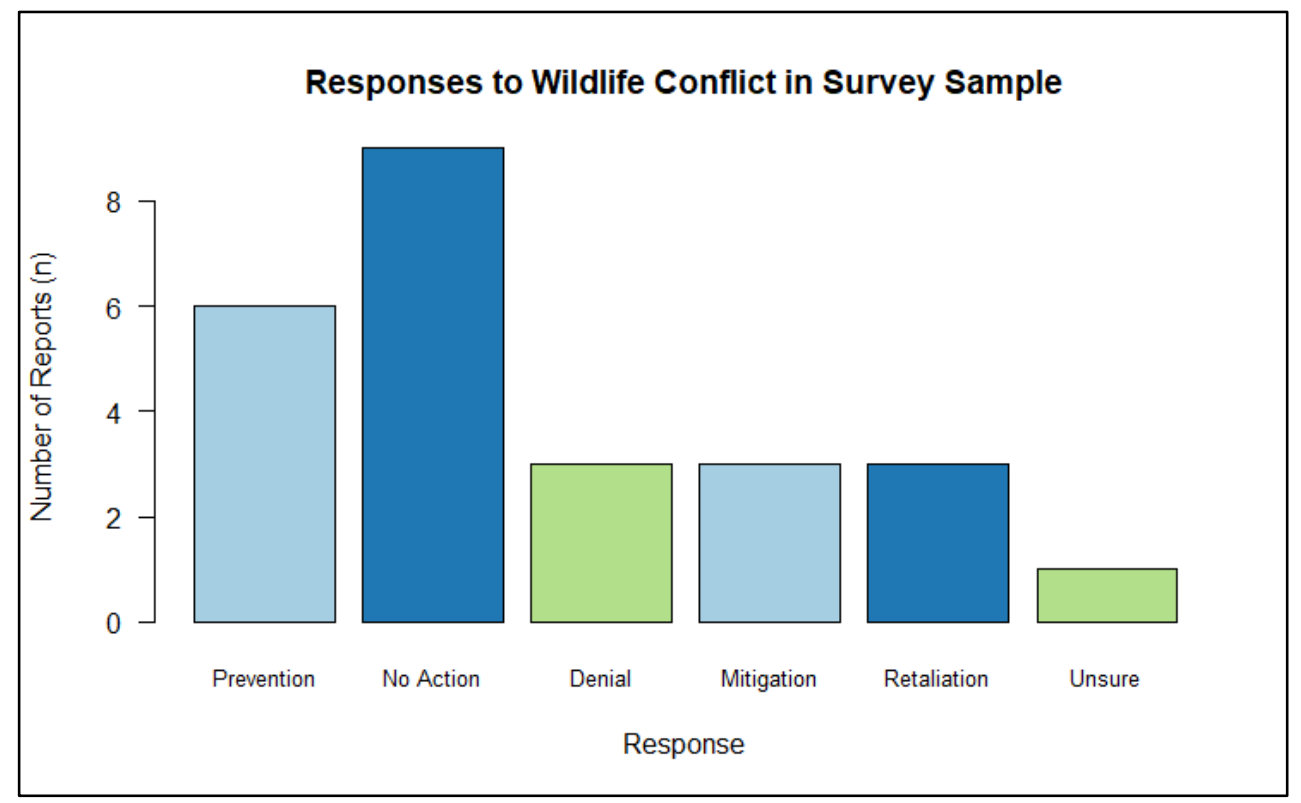

Figure 7.16: Response to wildlife conflict

Table 7.8: Table of recorded responses to wildlife conflict.

\begin{tabular}{|c|c|c|c|}
\hline Response & $\begin{array}{l}\text { Number of } \\
\text { reports (n) }\end{array}$ & $\begin{array}{l}\text { Percentage of } \\
\text { Responses }(\%)\end{array}$ & Responses included in category \\
\hline Prevention & 6 & $24 \%$ & 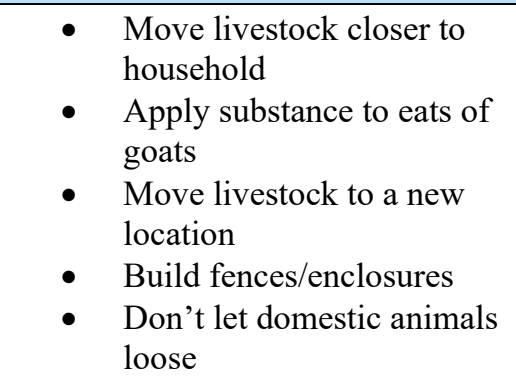 \\
\hline No action & 9 & $36 \%$ & $\begin{array}{ll} & \text { Not allowed to kill wildlife } \\
\text { - } & \text { Take depredation as a loss } \\
\text { - } & \text { Do nothing }\end{array}$ \\
\hline Denial & 3 & $12 \%$ & - It has never happened \\
\hline
\end{tabular}




\begin{tabular}{|c|c|c|c|}
\hline Mitigation & 3 & $12 \%$ & $\begin{array}{ll}\text { - } & \text { Report to local leadership } \\
\text { - } & \text { Get analysis done by local } \\
\text { veterinarian } \\
\text { - }\end{array}$ \\
\hline Retaliation & 3 & $12 \%$ & $\begin{array}{l}\text { - Look for the animal and } \\
\text { hunt it down } \\
\text { - Trap the animal }\end{array}$ \\
\hline Unsure & 1 & $4 \%$ & - Unsure of what is done \\
\hline
\end{tabular}

$54 \%(n=14)$ of the 26 respondents reported having lost livestock during the year. Not all respondents gave an answer to what happened to their animals but of the ones who did, six people reported illness as the cause of death, two reported wildlife as the cause, one reported domestic dogs as the cause, and one reported poison. When asked who should be responsible for domestic animals due to wildlife conflict within the community, members responded most with the government $(n=11)$, no one $(n=5)$, unsure $(n=5)$, the owner $(n=4)$, does not happen $(n=1)$. This question was followed by the programs that community members would have liked to see happen within the community. The question was open response but responses fell into several categories: insurance programs to replace livestock lost $(n=6)$, increased veterinary visits $(n=10)$, biodiversity conservation programs $(n=2)$, education programs $(n=2)$, prevention practices $(n=3)$ and unsure $(n=3)$ (Table 7.6).

Table 7.9: Desired programs for wildlife conflict mitigation

\begin{tabular}{|c|c|c|c|}
\hline Response & $\begin{array}{l}\text { Number of } \\
\text { reports (n) }\end{array}$ & $\begin{array}{l}\text { Percentage of } \\
\text { Responses (\%) }\end{array}$ & Responses included in category \\
\hline Insurance & 6 & $23 \%$ & $\begin{array}{l}\text { Dependent claims through } \\
\text { SADER (gov) - insurance } \\
\text { for livestock losses }\end{array}$ \\
\hline Veterinary & 10 & $38 \%$ & $\begin{array}{l}\text { - More vaccines and } \\
\text { medicine } \\
\text { - Animal health days }\end{array}$ \\
\hline Prevention & 3 & $12 \%$ & 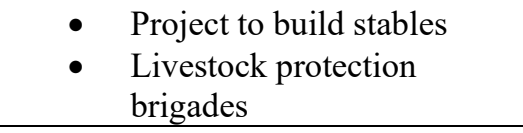 \\
\hline Biodiversity & 2 & $8 \%$ & $\begin{array}{ll}\text { - } & \text { Biodiversity conservation } \\
\text { - } & \text { Conservation of designated } \\
& \text { area for wildlife }\end{array}$ \\
\hline Education & 2 & $8 \%$ & $\begin{array}{ll}\text { - } & \text { Livestock management } \\
\text { workshops } \\
\text { - } \\
\text { Education on better } \\
\text { management practices }\end{array}$ \\
\hline Unsure & 3 & $12 \%$ & - Unsure of what program \\
\hline
\end{tabular}

The last block of questions in the interview inquired about participation in biodiversity monitoring, perceptions on the importance of biological monitoring, and impact of the 
program. Half of the respondents $(\mathrm{n}=13)$ reported having participated in biodiversity monitoring in some capacity by 1) field monitoring, 2) community workshops, or 3) field excursions during environmental education events. The next two questions asked community members to give a response on a scale of $1-5,1$ being low and 5 being high on the importance and impact of biological monitoring. 73\% $(n=17)$ ranked biodiversity as "very important" (5) for the community, and seven other respondents ranked it as "important" (4). The average response was 4.68 (standard deviation, 0.49; standard error, 0.10). When asked to rate whether having monitoring programs had changed knowledge, respect and/or actions towards wildlife in the community, four reported "very much" (5), seventeen reported "somewhat" (4), one responded "neutral" (3) and one respondent listed "not much" (2). The average answer was 4 and the standard deviation was 0.63 (standard error 0.12 ). The next question had participants clarify their "impact" rating. Free response answers were classified into four categories: action taken $(n=15)$, knowledge gained $(n=4)$, increased respect $(n=3)$, no change $(n=1)$, and not answered $(n=4)$. The timing of these actions remains unclear - some of the reported impacts could have happened before the study started and respondents were just reporting a general trend.

Table 7.10: Perceived impact of biological monitoring

\begin{tabular}{|c|c|c|c|}
\hline Response & $\begin{array}{l}\text { Number of } \\
\text { reports (n) }\end{array}$ & $\begin{array}{l}\text { Percentage of } \\
\text { Responses (\%) }\end{array}$ & Responses included in category \\
\hline $\begin{array}{l}\text { Action } \\
\text { taken }\end{array}$ & 15 & $58 \%$ & $\begin{array}{ll}\text { - } & \text { Protection of plants and } \\
\text { - } & \text { Lesimals hunting } \\
\text { - } & \text { Collect dead wood instead of } \\
\text { cutting down living trees } \\
\text { - } & \text { Not capturing wild birds for } \\
\text { pets } \\
\text { - } \\
\text { - } \\
\text { - } \quad \text { Bot leaving trash } \\
\text { Less deforestation }\end{array}$ \\
\hline $\begin{array}{l}\text { Knowledge } \\
\text { gained }\end{array}$ & 4 & $15 \%$ & $\begin{array}{l}\text { - } \begin{array}{l}\text { Learned how to conserver the } \\
\text { environment }\end{array} \\
\text { - Getting to see and know local } \\
\text { biodiversity }\end{array}$ \\
\hline $\begin{array}{l}\text { Increased } \\
\text { respect }\end{array}$ & 3 & $12 \%$ & $\begin{array}{l}\text { - } \quad \text { Respect plants and animals } \\
\text { - }\end{array}$ \\
\hline No change & 1 & $4 \%$ & - $\quad$ No significant change \\
\hline No answer & 4 & $15 \%$ & - $\quad$ No answer given \\
\hline
\end{tabular}




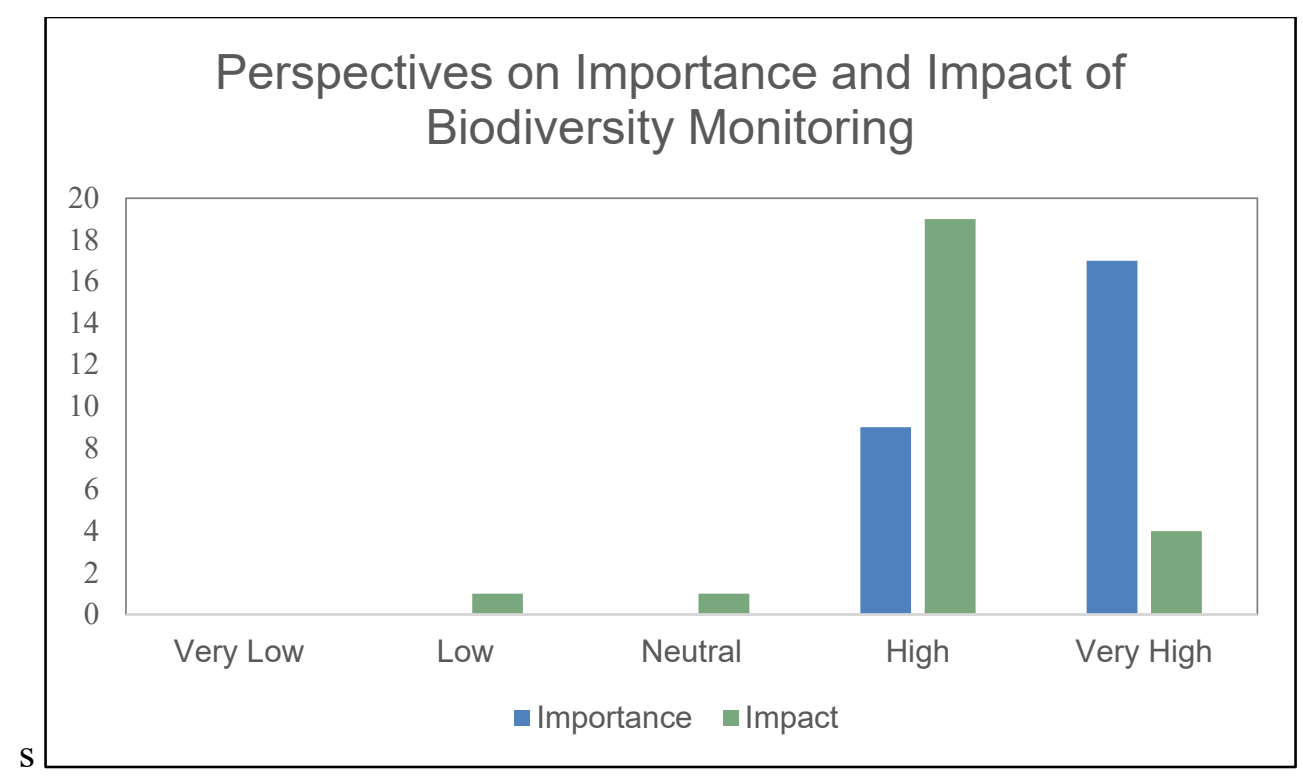

Figure 7.17: Perceived importance and impact of biological monitoring.

Overall, the interviews conducted in Santiago Coatepec from May-June 2019 demonstrated that the community values their local biodiversity and took actions to minimize HWC. They feared predators and feared for their own domestic animals due to past experiences. This shows that notions both fear and value of wildlife co-exist in the community. This can be seen by community members having me print photos of pumas for them, but also rumors of killing them when they caused damages. This also shows the contradictions present within the community. They value something as long as it has no impact on them. The majority of the community members have domestic animals and use them as a means of supplemental income, so any losses due to illness, depredation or drought is a considerable cost for them. This perception is reflected in the programs that people wanted to see in the town regarding HWC, noting that they would like more veterinary visits and a type of insurance for animals lost to depredation. The majority of respondents were women; this may be due to interviews conducted by going to each participating household during the day when men would perhaps be working in the fields. I also waited in the local plaza to interview people that other community members told me I should talk to. Discussed further in the ethnographic records are observations that some people may have changed their answers depending on what they thought I or CONBIODES wanted to hear. This might have impacted the results of this survey, especially questions about HWC and where they ranked the importance and impact of biological monitoring. Furthermore, due to the small sample size, the actual opinions and answers of the total population of Coatepec may be much different. There are 110 reported households in Coatepec, and I was only able to reach 29 of them within the time and conditions I was working under. 


\subsection{General Ethnographic Observations}

Simply looking at the interview data would be missing part of the picture in Coatepec. As a Peace Corps volunteer, I spent my days interacting with and observing the community. I did this so I could fit in without making too many cultural blunders, but also for my growing interest in community attitudes towards biodiversity and conservation. I spent many long days with community members on field monitoring events, listening as they talked about what things were like in the past and their aspirations for the future. Part of ethnographic analysis is to observe human behavior on a daily basis in order to understand underlying motivations for their actions (Newing, 2011). One informal way that I achieved this was to go outside on a walk every day around my community. This forced me to interact with those around me and served as a way for us to better understand each other. The following records are reported by what I observed (directly and indirectly) and what people said to or around me.

Perceptions stem from many different factors. In the case of Coatepec, I believe that many of the factors stem from its proximity to and dependence on nature. The main factors which seemed to shape people's mindsets were their own set of personal experiences juxtaposed with the unique cultural backdrop. Below is a figure demonstrating the influential factors in the community's conception of biodiversity (Figure 7.20). 


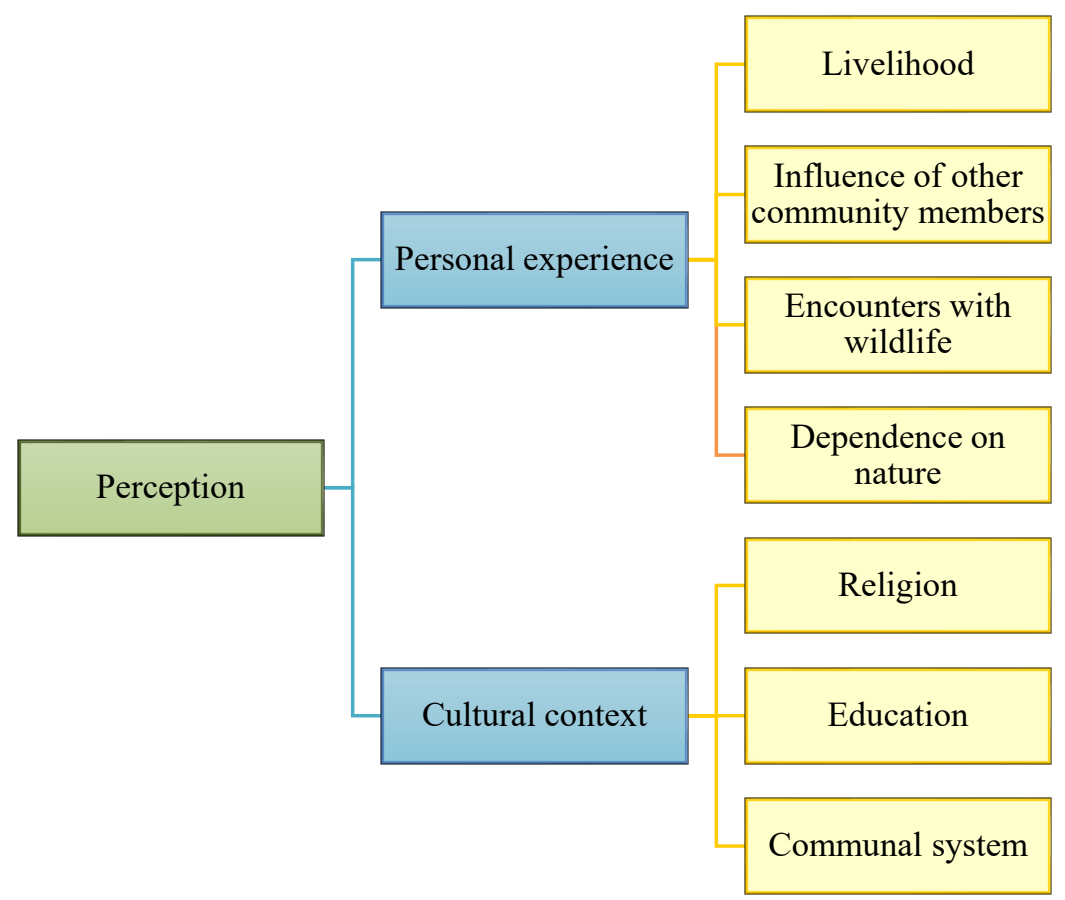

Figure 7.18: A diagram of factors influencing the perceptions about biodiversity in Santiago Coatepec.

During my first week on site in September 2017, a man told me about the puma his father had hunted down after a depredation event. I think there was still some confusion as to who I was at this point, so whilst telling me this story he showed a sincere sense of pride for what his father had done. People had other personal stories of predators that they liked to share with me, such as the shepherds who claimed that giant golden eagles would fly off with their goats. They told me of the time that twenty men went to go find a giant anaconda and that they brought it back to town (they eventually released it by the river).

They also told me about the strange unexplainable things they saw - such as the longtailed dragon that disappeared up into the hillside or being followed by a black feline through the night. They told me about their beliefs surrounding certain species - that all bats were vampire bats, and that a species of non-venomous lizard was very venomous. In general, snakes had all kinds of cultural myths surrounding them.

"How things used to be" was a large part of what people liked to share - they shared about how the hillsides used to be so green, how the rain used to fall, and how at one point there were no more white-tailed deer on the landscape because people had hunted them to depletion. People showed me where they used to wait and hunt for deer and the photographic evidence of the "biggest" one they ever hunted. 
Something that was hard for me was how to distinguish what was fact and what was fiction during this time. Rumors would circulate, but I was never certain if they were true. I noticed tendencies to both embellish stories and to hide details that they didn't want known. Such was the case of the rumors of one of the comisariado group's retaliatory killing of coyotes, or the rumor that for one of the town's festivals, the leadership groups served deer meat instead of goat meat.

In the interviews, I felt a real sense of this. People I could trust to tell the truth became essential. Regarding the interview validity, I asked the county veterinarian the same questions I asked community members as a way to triangulate reports Specifically, he reported that livestock had died that year "principally by illness and effects of the drought, as well as by predation by wild animals (coyotes and pumas), and equally by the presence of feral dogs." He also surmised the most likely response of a community member to a depredation event. "On occasion they (first) salvage/consume the meat and (second) usually try to learn the cause of death. In the case of feral dogs, they have organized (hunting parties) in order to look for them."

In a July $30^{\text {th }}$ recording of a public PROFEPA meeting with the reserve and comisariado groups involved in biodiversity monitoring in Zapotitlan Salinas, community members discussed what they should do after attacks from pumas, coyotes, and feral dogs (Table 7.11). In this roughly 18-minute exchange, I heard perceptions of risk and what to do about it. To my surprise, some community members had advice for the other groups. One community group member (Community member A) started the discussion. I transcribed the dialogue and added codes for reference.

Table 7.11: HWC dialogue at a PROFEPA meeting, July $30^{\text {th }}, 2019$.

\begin{tabular}{|c|c|}
\hline Dialogue & Code \\
\hline $\begin{array}{l}\text { Community Member A: "What are we to do - say I have two } \\
\text { chickens and a coyote takes one, what am I supposed to do now? } \\
\text { I depended on that chicken. Who is going to have to pay for it? } \\
\text { What are we supposed to do with the overpopulation of coyotes } \\
\text { in the area? We can't do anything to protect ourselves. I put up a } \\
\text { corral close to my house, but it didn't help." }\end{array}$ & Helplessness \\
\hline $\begin{array}{l}\text { PROFEPA personnel: "One thing you could do if it is a puma or } \\
\text { coyote is trap it and take it far away from where it is causing } \\
\text { damage." }\end{array}$ & $\begin{array}{l}\text { Prevention } \\
\text { advice }\end{array}$ \\
\hline $\begin{array}{l}\text { Community Member B (member of the same group as } \\
\text { Community Member A): "The coyote has turned into a plague } \\
\text { for us." }\end{array}$ & $\begin{array}{l}\text { Reality } \\
\text { Justification }\end{array}$ \\
\hline
\end{tabular}




\begin{tabular}{|l|l|}
\hline $\begin{array}{l}\text { Community Member C: "It isn't a plague it is part of the } \\
\text { ecosystem." }\end{array}$ & $\begin{array}{l}\text { Underlying } \\
\text { beliefs - } \\
\text { Outburst }\end{array}$ \\
$\begin{array}{l}\text { Community Member D: "The coyote is the one that killed the } \\
\text { deer and rabbits, not humans!" }\end{array}$ & $\begin{array}{l}\text { Empathy, } \\
\text { Blame }\end{array}$ \\
$\begin{array}{l}\text { Reserve Staff: "We can look for something to control the } \\
\text { population of coyotes, but you have to realize that this wouldn't } \\
\text { be a problem unless the people of the community were taking } \\
\text { their habitat and killing their natural predators." }\end{array}$ & \\
$\begin{array}{l}\text { Community Member E: "You know in back in my community, I } \\
\text { just have a few animals, but I don't have the resources to protect } \\
\text { them well, what do I do? The chicken also has the right to leave } \\
\text { its cage. Now they (coyotes and pumas) aren't afraid because we } \\
\text { don't kill them anymore. That is the problem." }\end{array}$ & \\
$\begin{array}{l}\text { PROFEPA Personnel: "You know it is illegal to kill wildlife and } \\
\text { you could go to jail." }\end{array}$ & $\begin{array}{l}\text { Consequences } \\
\text { of acting out }\end{array}$ \\
$\begin{array}{l}\text { Community Member F: "Just like humans go to the cities and to } \\
\text { the United States out of necessity, something better, animals do } \\
\text { the same. If there is nothing for them to eat in the wild, they will } \\
\text { come after our animals. Better to make sure you have a well- } \\
\text { made corral for your animals and then you won't have this kind } \\
\text { of damage - that (the corrals/personal management) is the } \\
\text { problem." }\end{array}$ & $\begin{array}{l}\text { Relating } \\
\text { wildlife } \\
\text { behavior to } \\
\text { human behavior } \\
\text { (understanding) }\end{array}$ \\
\hline
\end{tabular}

During this conversation, the tone moved from helplessness, to anger, to consolation of the concerned parties. The conversation was circular in natural and kept coming back to the subject of what to do about HWC. When living in proximity to nature, that will always be a question one must face. There is some understanding of the animals' behavior from some of the community members, and in the case of this meeting, they are there because they want solutions to their real problem of losing their source of income or source of food.

Depredation was not the only type of HWC that community members faced. A large problem for the community members participating in animal husbandry was illness and death of their livestock by paralytic rabies. The main vector of this disease was vampire bats (Desmodus rotundus). Two caves in the community were identified as containing vampire bat colonies. During the two years of my service, a professor helped to disseminate information on the benefits of healthy bat communities in the reserve. In order to protect beneficial species, and with the "unofficial" consent of the reserve, a 
team was able to perform a culling of the problem populations to lessen the impact on livestock husbandry within the community. No one reported livestock losses due to rabies after the culling. This seemed like a worst case scenario to me, but in the week after the culling, a community member came to me with a live bat they had found in their house and instead of killing it they asked what kind of "murcielago" (bat) it was so that they would know what to do. He understood to some degree that many species of bats provide benefits to human communities through seed dispersal, pollination, and insect control.

I also documented my experiences working with women and youth. In the first group of comisariados I worked with, only one woman was actively involved in biodiversity monitoring. She was the quickest one to understand how to use the equipment, was on time, and was prepared for anything. She was always ready and willing to help at a moment's notice. The following comisariado groups each had women involved in biodiversity monitoring. For several months, I would meet with the women of one group to go over how to use a GPS, camera trap, normal camera, and computer. They had never touched this equipment or a keyboard before being elected by the assemblea into their positions. When we went to go set up cameras together for the first few times, they talked about how lucky they felt to have the opportunity to do this - that they had not been to the river (just outside of town) for 30 years or more since they were children. They loved getting to learn something new, and even though they lacked confidence at first, they learned how to use the basic equipment (I left them a manual in case they forgot a step). The youth in Coatepec showed the same level of enthusiasm. They were the ones who pushed for a conservation group and to continue to do camera trap monitoring even when the comisariado of the ejido land system did not want to anymore. A fifth grader suggested putting a up signs near caves to protect the threatened species of bats inside. They also were the ones who drove the effort to make Coatepec more sustainable through recycling programs and reforestation of native plants in the main plaza. They cared about seeing interesting animals on video and camera and their interest persuaded their parents and relatives to be interested too. When we went on field trips to see their local biodiversity, the class sizes almost doubled, with each student bringing at least one adult with them. Connecting with them and learning with them was important to impact their malleable perceptions, which will ultimately guide the future of the community. 


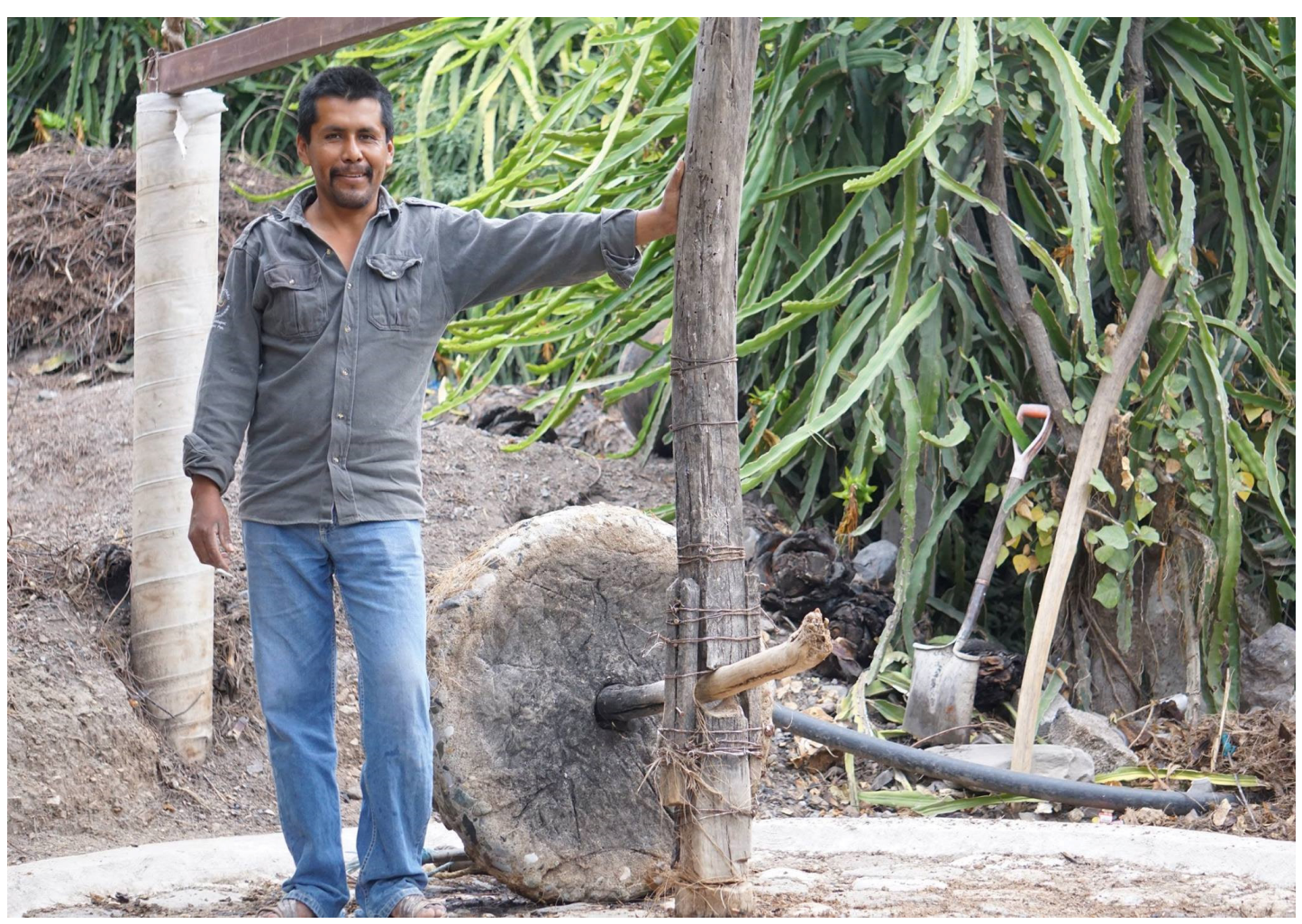

Figure 7.19: Mezcal and dragon fruit production are the main livelihoods of people in Coatepec (photo by the author).

Santiago Coatepec is dependent upon the local environment for food, building materials, water, medicine, fuel, religious customs, and livelihoods. Their primary income-generating products come from bat-pollinated native species, such as maguey and dragon fruit (figure 7.15). Supplemental income such as animal husbandry, palm weaving, and wood collection also depend on access to communal land. At all times of the year, there were delicious fruits, bugs and herbs to be harvested. Small annual plants such as "verdulagas", "pipichas" and "papaloquelites" would grow as soon as the first rains came. Community members would go to great lengths to harvest prickly cactus fruits like "pitaya", "chende", and "jiotilla" or "pochote" seed pods during the dry season, and different larvae like "pochoquiles" and "cuchama" would be collected in the months between dry and wet seasons. There were many traditional herbal medicines known and used within the community. One medicinal plant, "mala mujer" (Cnidoscolus sp), had many uses. It was used to not only to treat stomach aches, but to make cheese from goats' milk, and for the nutritious value of its seeds. During religious celebrations, Dasylirion sp (cucharitas), Pseudalcantarea grandis (helechos), as well as Tillandsia sp (paxtle) would be used to decorate arches and pillars. Copal (Bursera $s p$ ), or frankincense, was also widely used to smudge attendants of religious celebrations. Specific celebrations called for specific plant species. Orchids were used in churches during patron saint celebrations, marigolds used during the Day of the 
Dead, 200-year-old biznaga cactuses used for a bread pastry during the celebration of "Los Reyes Magos", and palms used during Palm Sunday. Primary materials for building (wood, stone, clay, sand, fiber) and for wood burning stoves were collected from communal land. Except during very dry periods, most of the town's water came from wells and natural springs. Out of this dependence, I saw a number of strategies to ensure the continued usability of their natural land resources.

Even though Coatepec is constituted by a common land ownership model, I observed systems in place to prevent a "tragedy of the commons" scenario. In fact, their management system was more similar to Elinor Ostrom's criteria of common pool resources (Ostrom, 2002). In the community, this meant controlling how many animals were let graze on common lands, moving livestock from one location to another at the change in season, and controlling how many resources were harvested from common land (maguey, wood, etc.). From what I observed, maguey, palm and green wood removal were specifically controlled. Each communal land management type (bienes comunales, ejido, fondo legal) acted as a protective group that would uphold land use agreements. Community members were held accountable by pressure from other community members, amplified by the practice of "assembleas," or community meetings, where expenditures, debts and dues would be announced by date and person. The "assemblea" was also where large decisions regarding the community would be made. There was also a system in place to fine people who did not follow the standards set in place by the "assemblea." For example, if someone's cow ate another man's corn, the cow owner would pay the corn producer, and if he didn't the corn producer would go to the comisariado group to get reinforcement.

Directly in relation to human-wildlife conflict, I also noted strategies by the community to minimize potential risks from wildlife. The table below (Table 7.12) mentions some of the measures that I observed during my time in the community. Some of these techniques started or happened during my service (environmental education, biological monitoring, removal of individuals and target species), while the rest were already in place.

Table 7.12: Measures taken to mitigate human-wildlife conflict in Santiago Coatepec.

\begin{tabular}{|c|c|c|}
\hline Measure & Technique & Application \\
$\begin{array}{c}\text { Behavior } \\
\text { modification of } \\
\text { humans }\end{array}$ & $\begin{array}{c}\text { Environmental } \\
\text { education }\end{array}$ & $\begin{array}{c}\text { Classroom visits, nature field trips } \\
\text { and adult workshops }\end{array}$ \\
\hline $\begin{array}{c}\text { Behavior } \\
\text { modification of } \\
\text { community } \\
\text { members }\end{array}$ & $\begin{array}{c}\text { Livestock } \\
\text { management } \\
\text { practices }\end{array}$ & $\begin{array}{c}\text { Vaccinating and rotating livestock 1- } \\
2 \text { times per year. }\end{array}$ \\
\hline
\end{tabular}




\begin{tabular}{|c|c|c|}
\hline $\begin{array}{c}\text { Reducing costs of } \\
\text { conflict }\end{array}$ & $\begin{array}{c}\text { Increasing benefit } \\
\text { of wildlife } \\
\text { conflict }\end{array}$ & $\begin{array}{c}\text { Community biological monitoring } \\
\text { programs }\end{array}$ \\
\hline $\begin{array}{c}\text { Reducing costs of } \\
\text { wildlife conflict }\end{array}$ & $\begin{array}{c}\text { Compensation by government for } \\
\text { livestock loss to depredation }\end{array}$ \\
\hline Guarding practices & $\begin{array}{c}\text { Human and canine } \\
\text { guardians }\end{array}$ & $\begin{array}{c}\text { Sheep and goat herding by dogs and } \\
\text { humans }\end{array}$ \\
\hline Physical separation & $\begin{array}{c}\text { Chemical } \\
\text { separation }\end{array}$ & $\begin{array}{c}\text { Use of scented cream to deter } \\
\text { vampire bats from livestock }\end{array}$ \\
\hline Whysical separation & Fencing & $\begin{array}{c}\text { Enclosures of poultry, pigs, goats } \\
\text { and sheep during the night. }\end{array}$ \\
\hline Habitat Buffer & $\begin{array}{c}\text { Wildlife food } \\
\text { source maintenance }\end{array}$ & $\begin{array}{c}\text { Banning of hunting wildlife in } \\
\text { common land. }\end{array}$ \\
\hline Lethal control & $\begin{array}{c}\text { Removal of } \\
\text { problem species }\end{array}$ & $\begin{array}{c}\text { Preservation polygons, where local } \\
\text { groups cannot farm or use the land }- \\
\text { much of the bienes comunales } \\
\text { territory. }\end{array}$ \\
\hline Lethal control & $\begin{array}{c}\text { Targeted removal } \\
\text { of individuals }\end{array}$ & $\begin{array}{c}\text { Rumor of retaliatory action taken } \\
\text { against coyotes. }\end{array}$ \\
\hline
\end{tabular}

I also observed that certain leadership groups valued biological monitoring programs more than others. After six months of biological monitoring, the first ejido governing group decided that the experience was not beneficial to them due to the expenditures they incurred on each monitoring event (food and time spent away from a wage-earning activity). I proceeded to work only with the bienes comunales leadership group and group of interested youth for a few months. In January of 2019, the assembleas of each communal land group elected new representatives. The shift in town leadership resulted in renewed interest in monitoring and nature conservation efforts in both bienes comunales and ejido groups.

The community had other social and environmental characteristics that played a role in its vulnerability to damage by wildlife. One major force was the long dry season which lasted for seven to eight months of the year. Seasonal drought made livestock more susceptible to predation, disease and death. Having weaker animals far away from the community and exposed carcasses increased risk of disease transfer and animal loss during the dry season. Since feeding animals with purchased grains surpasses the worth of the animal, placing animals on common land is a risk many community members were forced to take. Coatepec is especially vulnerable because the majority of its inhabitants participate in non-wage labor and rely upon supplemental income (such as selling a goat or a cow) when times are hard. Additionally, religious background (strands of Christianity) has shaped the community's beliefs on wild animals. 
Christianity seems to fall under Kellert's (1993) "utilitarian" nature-related value typology, where humans view nature as being most valued for its instrumentality/functionality (Kellert, 1993). One must consider the role that certain animals play in the Bible (e.g., the snake in the Garden of Eden) as well as the overall implication that animals were placed on Earth purely for the use of man.

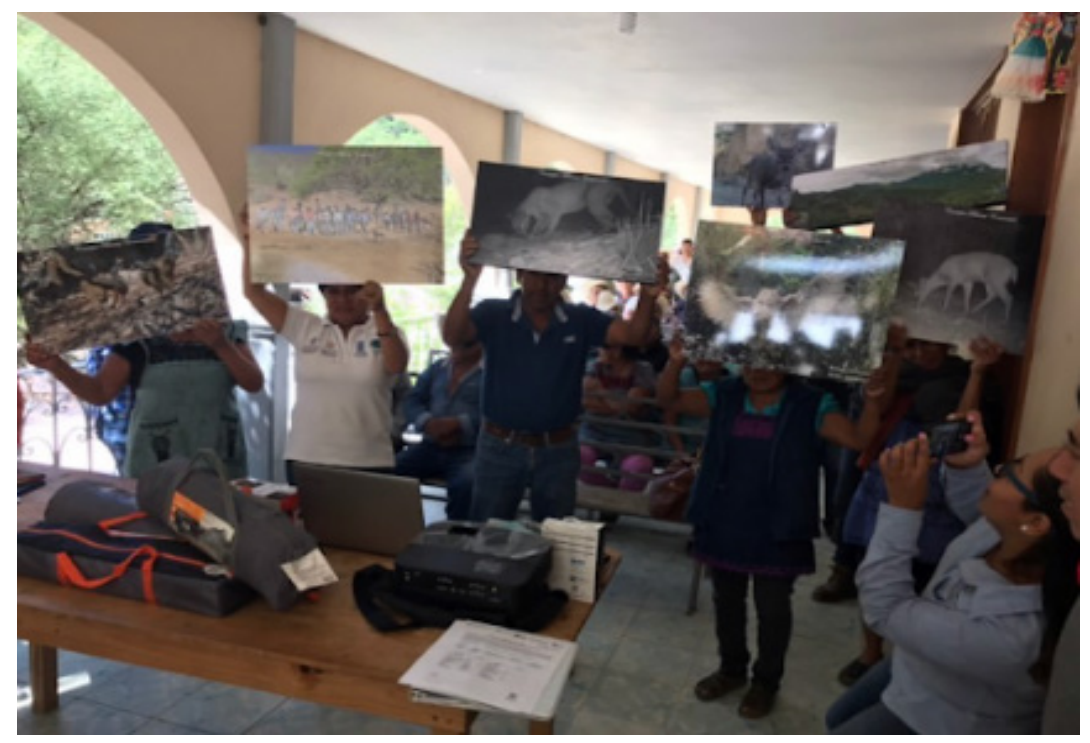

Figure 7.20: Community members showing off their photos for the presidential area.

Throughout my stay in Coatepec, there seemed to be a general interest in biodiversity. I saw this in a number of ways, one of which was being asked on a regular basis to produce educational materials for them. For example, I created calendars with photos of wildlife, videos of field monitoring results, large canvas posters for the presidential area, personal copies of photos of wildlife, and framed photos of the wildlife to hang in the presidential and comisariado offices (Figure 7.22). During a final assemblea, these framed photos were given to the community and a few members stood up to speak about their experience. "This project has left an impact on us. We have learned to conserve our native flora and fauna; we depend on a functional ecosystem and should not see ourselves as separate from nature. Something else that I have learned from you during this project, is that differential treatment wasn't given based on economic levels, gender, political stance, religion... a practice we have lacked here." (Statement by Don Cesario Correa, Consejo de Vigilancia - Ejido, Santiago Coatepec, Caltepec, Puebla). Through a combination of ethnographic methods, I was able to get a better understanding of the community's thoughts and perspectives surrounding biodiversity conservation and its reaction to HWC. 


\section{Discussion}

In all, the two-year biodiversity monitoring and environmental education project in Santiago Coatepec quantified the many species that were present on the landscape and collected qualitative data on the impact these wild animals had on a community with a strong importance on livestock husbandry. This study offers a rich interdisciplinary set of data that can help understand complexities of living on the urban-nature interface. It was spurred by early observations surrounding how humans and their domestic animals share the same environment, especially when human-wildlife conflict may occur. We now live in a world where we are losing species at unprecedented rates and learning how to coexist is of the highest importance. The efforts of this study demonstrated the strengths and weaknesses of conducting a study that both had to satisfy the desires of community partners and produce sound scientific results.

\subsection{Camera Traps}

Camera trap data allowed me to generate a list of species present on the landscape and a greater understanding of the spatial and temporal shifts apparent in each species. There were twenty-four different mammals documented across the 18 camera stations deployed over two years for a total of 1650 camera trap nights. After removal of errors, I analyzed 1121 nights of camera trap data. Seasonal records show observational concentrations of both livestock and wildlife in the dry season, but more so with wildlife than in livestock. Certain camera stations had high occupancy all year round, where others had strong seasonal differences. Wildlife occupied camera station locations that were not occupied by livestock. The camera stations that had greater occupancy of wildlife were found in similar habitat types (rugged terrain or close to permanent sources of water). Wildlife densities over a period of 24 hours had strong peaks late at night and early morning. Domestic animals had similar activity densities throughout the day. Although video data was tedious to code, there was key information that only videos could provide, such as interspecific and intraspecific behaviors that would likely not have occurred if I had been present to witness them. Behavior patterns differed between wildlife and livestock, however, most behaviors exhibited by both groups were locomotive. Negative interspecies interactions occurred more often between livestock and wildlife, than within either group (livestock to livestock or wildlife to wildlife) - $71 \%$ of the behaviors between wildlife and livestock categorized as negative. Camera traps proved to be an effective tool for documenting species behavior and distribution.

The videos I labeled as interspecific conflict or negative interactions were very clearly detrimental to at least one of the species (e.g., vampire bats attached to cows). Interspecific conflict may result in damages to both livestock and wildlife populations. These conflicts are far more likely with the type of free-range grazing that occurs on 
the communal land. Livestock is simply let loose for a period of time and will most certainly interact with the natural world during that time. Trouble emerges when community members of Coatepec find damages by wildlife on livestock (but not the other way around - which the data indicated is $71 \%$ more likely to occur).

Humans are directly involved with the natural world in the community and were caught on camera videos 308 times. Their presence on the landscape has impacted wildlife species - perhaps even more than livestock itself. They were also shown to have a negative impact on wildlife community, such as in videos of community members carrying guns or with squirrels they had shot and killed, or confessions in interviews and ethnographic observations of hunting parties for specific predators. Of these, most contained other domestic animals such as dogs, donkeys, and horses. Dogs and donkeys have been shown to have an effect on wildlife populations in other studies. Many videos showed humans carrying wood they had collected. There is video evidence of dogs present on the landscape even when not with human owners. Though it would be hard to determine if these dogs had an owner or if they were feral, some of the late-night triggers point to the inference that feral dogs might be active on communal land. Most reports of feral dog activity came from the neighboring community of Caltepec, but this does not mean that their range would not extend into parts of Coatepec.

Although some of the results demonstrated that there was a significant separation in space, time and behavior between wildlife and livestock, there was not enough evidence to clearly implicate livestock presence as the main driver of these deviations. There are many factors that influence the behavior, distribution and densities of species, and assuming that the variations witnessed in this study were all due to the covariates I chose to record could lead to type I errors in the data. The scope and size of the study was limited and largely dealt with unmarked population groups (1650 camera trap nights). Statistical mechanisms and models were uses to overcome this; however, the limited sampling effort and study design has implicit effects on the quality assurance of the study results. The dataset was hard to adapt for use by the packages specifically designed in Rstudio for camera trap data and needed significant data tidying. Additionally, with any hand coding, there are opportunities to commit errors in the data transcription. Specifically, in the transcription of behavioral data, although I transcribed what I thought I saw happen, I may have mischaracterized a behavior such as a reproductive behavior for a social behavior. All of this came with the nature of the study, as it was a Peace Corps community-driven project that had to cater to the community just as much as it did to scientific design. I had to work with community members on their own terms and time. This led to differing sampling effort, which was especially apparent during the production and harvest season of dragon fruit. Cameras were moved to different spots when community members wanted to survey if neighboring community members were stealing livestock. Community interest in the project waxed and waned, such as when for 6 months I only worked with bienes 
comunales and not with the ejido until the elections came and the new leaders spurred renewed interest in the project.

In sum, that we know that livestock and human presence has a negative effect on wildlife, however other than negative behavioral interactions when both were caught in the same video, I am unable to prove that the difference in spatial and temporal behaviors is only due to livestock.

\subsection{Surveys}

The interview data demonstrated that although people value biodiversity and have some understanding of what it does for them, they are still afraid of the threats that living in proximity to nature brings. The 29 surveys conducted in the community of Coatepec in May-June of 2019 show trends in perceptions and occurrences. Namely, the 2019 survey finds that community members have less livestock, are participating less in animal husbandry, have suffered losses due to depredation, drought and disease, and it reports feral dogs as present on the landscape. Every individual surveyed owned domestic animal (average 20 animals per household). Based on the survey demographics, the respondents were majority women who did not take part in the wage labor economy. Livestock husbandry was important as a supplemental source of income. When asked, 18 respondents listed one or more wild animal as a threat to the community. However, 6 community members reported a native predator and 16 a native prey species as valuable native species. and the majority of people interviewed $(n=17)$ found biological monitoring to be very important and have a high impact on local attitudes, knowledge and actions towards wildlife $(n=19)$. Many people listed mitigation and prevention behaviors to minimize HWC instead of lethal action.

I verified community member reports by through discussions with the local veterinarian and the town leadership groups. Their numbers were more accurate, and I trusted them to report to the best of their ability. The discrepancy between their answers and other respondents gave me a glimpse into the perspectives of community members. It highlighted for me what was important to them, and perhaps, what they really thought about wildlife and conflict in general. Many people could recognize the importance of wildlife such as deer and rabbits, most likely due to their desire to hunt them, but a surprising number of participants recognized top predators to be valuable as well. This could be due to the long history of wildlife being used in symbology through Mexico's history. The golden eagle is depicted on the flag and felines, snakes, and bats were considered gods.

Though only a total of 29 households were interviewed, this is still pertinent to purposive sampling methodologies. The time investment in each interview was approximately 2 hours, as it is the custom that people will invite you into your house for refreshments and foodI tried to capture a well-rounded distribution using the 
background information to select candidates. It was important for me both to talk to local leadership and community members who depended on the land for their livelihood. Though ideas about wildlife seemed to take on a new appreciation, my conclusion is that two years of biological monitoring were not enough to change final decisions of community members if there were a significant HWC. I was witness to lethal action in the community against wildlife when they felt the losses they had sustained were too great.

Surveys and interviews served as a good mechanism to get a glimpse of the attitudes and perceptions of local community members, however it was not always possible to discern what they truly thought and what they were telling you in order to appease you given diverse social dynamics. The 2019 interviews had very different conclusions that those of the 2017 group survey conducted by CONBIODES personal. This may have been due to the fact that overall, the community trusted me on a slightly deeper level and were more willing to report truthful answers (on average). Though they might have embellished their answers on their views of the importance of wildlife and the impact that biological monitoring had on shifting their actions and attitudes, they did predominantly report mitigation and prevention behaviors instead of disproportionate actions taken against wildlife should there be a HWC event. This may have been more due to living within a Nationally Protected Area where, in many ways, they benefited most by following its mandates (though not necessarily enforced). Community members reported the occasional occurrence of retaliatory actions taken when deemed necessary by community members and communal land leaders. 


\subsection{Ethnographic Conclusions}

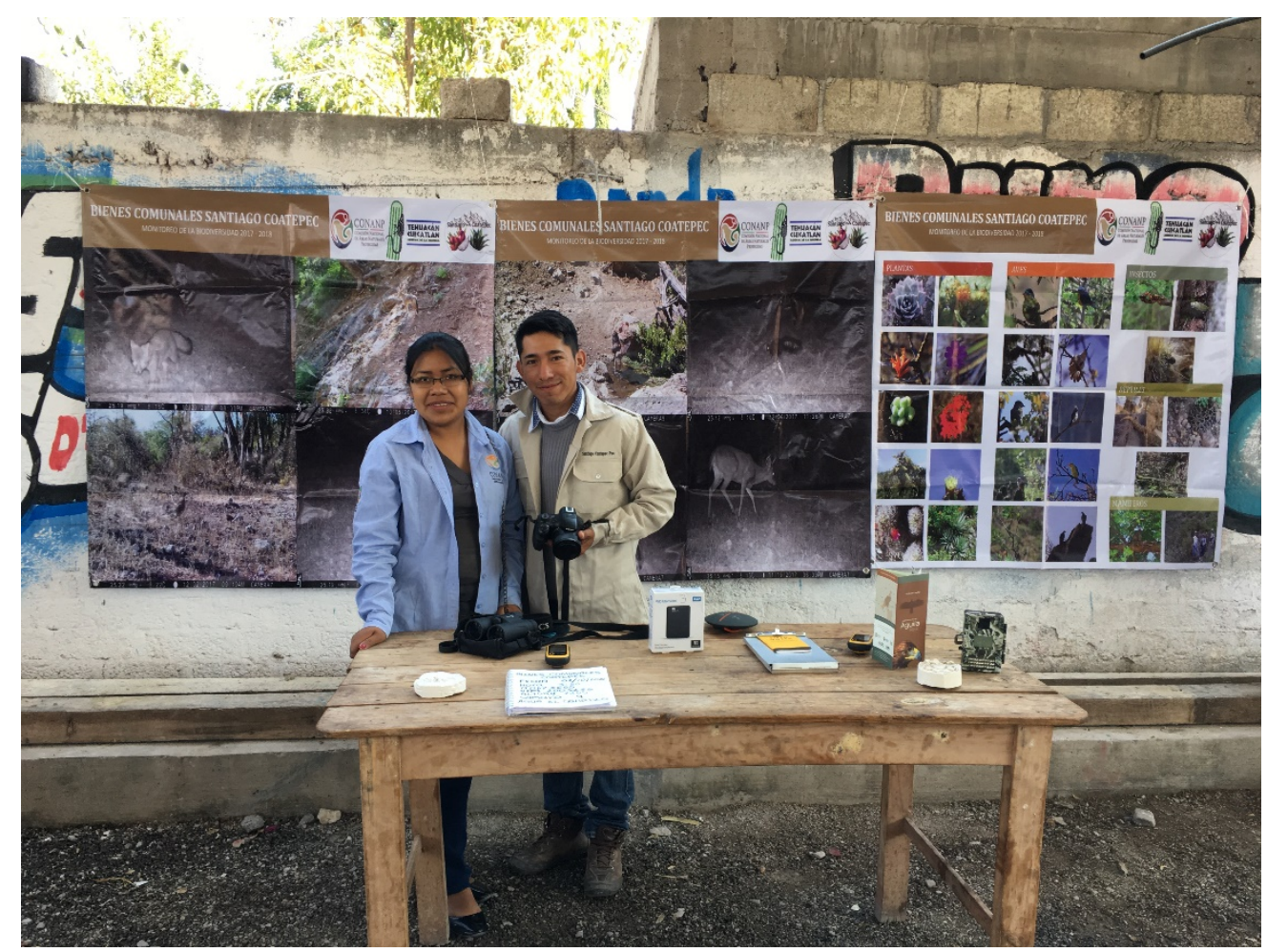

Figure 8.1: Community members René Balderas and Diana Lezama Luna at an environmental education event in the municipality (photo by the author)

While I was in Coatepec I observed many thoughts, actions and perceptions of wildlife and the threat of HWC.

HWC is a complex issue that often requires a great deal of time and effort to fully understand and interpret underlying motivations and beliefs. The Santiago Coatepec community has coexisted with nature for hundreds of years, but I did not see that the long exposure had any mitigating impact on their perceptions of the threat of damages by wildlife. In fact, there was evidence that showed the opposite, that they had even more deeply seated anti-wildlife beliefs (such as their fears about snakes and bats) than perhaps communities that had newly expanded into nature. Based upon the total livestock loss the community incurred in 2018-2019 (60 bovine, 100 ovicaprid, 14 equine), much of which was caused by paralytic rabies, their fears were indeed founded upon reality. Community members were forced to abide by the Biosphere Reserve rules (e.g., no hunting), and their actions were disproportionate to the damage they endured in the opposite direction one might anticipate. However, depending on the veracity of the rumors about retaliatory killing of problem wildlife, the response could be closer to proportionate. 
Aside from that event, lethal action was still a tool being utilized by the community, but its use was seemingly few and far between. I had various conversations with community members where I could not tell if they viewed the reserve as a blessing or as an enemy. As one notes in the subtext of transcribed PROFEPA meeting above (Table 7.10), one can discern the accusatory and helpless tones expressed by community groups when facing the realities of HWC inside a protected area. Within the reserve, there were entire communities that refused to work with the CONANP personnel for reasons most likely stemming from feelings of power disparity. Santiago Coatepec, however, took advantage of projects and programs that the government agencies offered which concomitantly helped them to mitigate potential risks and damages from HWC. Examples of these multipurpose programs include biological monitoring, environmental education, and the establishment of a "livestock insurance program" (actual status unknown) for members who had suffered losses due to depredation.

Extensive education and monitoring events in Coatepec did appear to provide a new lens through which to view biodiversity. The interviews highlighted the importance and impact that biological monitoring had on the community. Even though a legal framework was already in place, when I arrived in 2017 there was an ambivalence to the natural world. Although wildlife persecution was and still is against the law, the ability to enforce that law was minimal at best. Often people would tell me "it shouldn't take an outsider for us to see and value what we already have." As for long term change within the community towards HWC, the feelings of animosity or fear towards certain species (puma, coyote, snakes, bats) may persist even after conflict has been substantially reduced. Only with mitigation strategies which engender greater understanding of community vulnerabilities, perceptions and social factors, will there be successful reduction of conflict. Although my two years of educational work did produce a slight shift, the work that is needed may be on the magnitude of generations.

\subsection{Other Factors to Consider}

The context of my study had an impact on the results. Mexico has had a vast and interesting history that lives on into the present day. Nature has been weaved into the cultural subtext with deeply seated views both of fear and reverence. In fact, even down to the etymology these perspectives persist. Mexican Spanish is intertwined with the Nahuatl language - Santiago Coatepec was conquered by both mega-forces. It can even be witnessed in the name: "Santiago" a Catholic Saint depicted as a white man a horse trampling a brown man, and "Coatepec" meaning "Hill of Serpents" in Nahuatl. Both names elicit a sense of fear and reverence for the dominant cultures. The sense of Mexico being a conquered country has had many effects on the psyche and reactions of its people. This dynamic may have been extended by the delineation of the region as a Nationally Protected Area, as it plays into power dynamics historically present. 
Perhaps due to this, some individuals feel the need to act subversively. However, there have been general steps to empower portions of the population long subjugated into submission. Women are beginning to have a role outside of the confines of their homes. In a small community, this progression happens on a much slower time frame. However, in the elections that took place in Santiago Coatepec in January 2019, women were elected to positions of leadership within the comisariado groups. Their perspective could bring adoption of different views of local wildlife and biodiversity for the future.

The abiotic features of the study area also had an influence on the unique abundance seen in the area. Even with nutrient poor soils derived from the surrounding limestone, the climate and hydrology created a rich abundance in the natural world. The biosphere reserve has one of the greatest concentrations of bat species diversities since they do not have to migrate long distances to find suitable food source all year round. However, with the predictions of climate change in this region, the natural profusion will be placed in elevated risk. These threats include increased dependence by local communities, effects of drought, the onset of pests and plant pathogens, and perhaps greater potential for HWC as native food sources diminish. Specific to Coatepec, as the community depends upon natural resources, effective strategies must be developed. Due to its location within a UNESCO world heritage site, the community make have access to government resources and programs to actively steward their natural resources. The reserve has the framework to create long-term solutions, however, even with its team of dedicated personnel, there are many hard-solve, reoccurring issues. The RBTC has drawn international interest and therefore, has the unique ability to implement creative programs to satisfy the needs of its inhabitants. To mitigate for associated risks of HWC and improve livestock husbandry practices, many years of work will be necessary. 


\section{Reference List}

Acuna-Soto, R., Stahle, D. W., Cleaveland, M. K., \& Therrell, M. D. (2002). Megadrought and Megadeath in 16th Century Mexico. Emerging Infectious Diseases, 8(4), 360-362. https://dx.doi.org/10.3201/eid0804.010175.

Alcocer, J., \& Bernal-Brooks, F. W. (2010). Limnology in mexico. Hydrobiologia, 644(1), 1-54.

Ambiente, P. F. D. P. A. (2016, September 12). NORMA OFICIAL MEXICANA NOM-059-SEMARNAT-2010. Retrieved from https://www.gob.mx/profepa/documentos/norma-oficial-mexicana-nom-059semarnat-2010

Amor-Conde, D., F. Colchero, E. Huerta, C. Manerola, E. Pallares, A. Rivera, A. Soler. (2011). El jaguar como elemento estratégico para la conservación. Comisión Nacional para el Conocimiento y Uso de la Biodiversidad, Corredor Biológico Mesoamericano. México No. www.conabio.gob.mx; www.biodiversidad.gob.mx/cbmm ISBN 978-6077607-55-7

Aranda-Sánchez, J. M., F. Leyva, L. Charro. (2012). Manual para el rastreo de mamíferos silvestres de México. Comisión Nacional para el Conocimiento y Uso de la Biodiversidad. (CONABIO). Mexico. 260 pp

Arroyo-Quiroz, I., R. García-Barrios, A. Argueta-Villamar, R. J. Smith, R. Pérez Gil Salcido. (2017). Local perspectives on conflicts with wildlife and their management in the Sierra Gorda Biosphere Reserve, Mexico. Journal of Ethnobiology 37(4)

Assies, W. (2008). Land tenure and tenure regimes in Mexico: An overview. Journal of Agrarian Change, 8(1), 33-63. http://doi.org/10.1111/j.1471-0366.2007.00162.x

Bada, Ferdinand. (2018, October 23). What Are the Major Natural Resources Of Mexico? Retrieved from https://www.worldatlas.com/articles/what-are-the-majornatural-resources-of-mexico.html

Banco de México. (n.d.).

https://www.banxico.org.mx/SieInternet/consultarDirectorioInternetAction.do?sector $=1 \&$ accion $=$ consultarCuadro\&idCuadro $=$ CE166\&locale $=$ es. Retrieved April 26, 2020, from

https://www.banxico.org.mx/SieInternet/consultarDirectorioInternetAction.do?sector $=1 \&$ accion $=$ consultarCuadro\&idCuadro $=\mathrm{CE} 166 \&$ locale $=\mathrm{es}$ 
Biles, J. J. (2010). Geo-Mexico: The Geography and Dynamics of Modern Mexico. Journal of Latin American Geography, 9(2), 171+.

Biodiversity in Mexico. (2015, January 1). Retrieved March 18, 2020 from http://www.southernportal.com/biodiversity.html

Boholm, A. (1998). Comparative studies of risk perception: a review of twenty years of research. J. Risk Res. 1, 135- 163.

Botello Lopez, F.; (2006). Distribución, actividad y hábitos alimentarios de carnívoros en la Reserva de la Biosfera de Tehuacán-Cuicatlán, Oaxaca. Published Master's Thesis. Universidad Nacional Autónoma de México (UNAM), México City, México.

Bouquet, E. (2009). State-led land reform and local institutional change: land titles, land markets and tenure security in Mexican communities. World Development, 37(8), 1390-1399.

Bridges, A. S., and A. J. Noss. 2011. Behaviour and activity patterns. Pp. 57-69 in: A. F. O'Connell, J. D. Nichols, K. U. Karanth. eds., Camera traps in animal ecology: methods and analyses. Springer, New York.

Calderón, L. Y., Heinle, K., Rodríguez-Ferreira, O., \& Shirk, D. A. (2019). Organized Crime and Violence in Mexico. San Diego, University of San Diego, disponible en: https://issuu. com/pajaropoli tico/docs/organized-crime-and-violence-in-mex.

Campbell, L., Kaufman, T., \& Smith-Stark, T. (1986). "Meso-America as a linguistic area". Language. 62 (3): 530-58. doi:10.2307/415477. ISSN 0097-8507. JSTOR 415477. OCLC 1361911

Caravaggi, A., Banks, P. B., Burton, A. C., Finlay, C. M., Haswell, P. M., Hayward, M. W., ... \& Wood, M. D. (2017). A review of camera trapping for conservation behaviour research. Remote Sensing in Ecology and Conservation, 3(3), 109-122.

Central Intelligence Agency. (2020). Mexico. In The world factbook. Retrieved from https://www.cia.gov/library/publications/the-world-factbook/geos/mx.html

Chandler, R. B., \& Royle, A. J. (2013). Spatially-explicit models for inference about density in unmarked populations. Annals of Applied Statistics, 7, 936-954.

Coatepec (Caltepec, Puebla). (n.d.). Retrieved March 28, 2020, from https://mexico.pueblosamerica.com/i/coatepec-4/ 
Cobb, A. B. (n.d.). Mexican Secretariat for Natural Resources - environmental, United States, EPA. Retrieved March 20, 2020, from http://www.pollutionissues.com/Li$\mathrm{Na} /$ Mexican-Secretariat-for-Natural-Resources.html

CONABIO. (1998). La diversidad biológica de México: Estudio de País. Comisión Nacional Para El Conocimiento Y Uso de La Biodiversidad, 605(1-3), 129-37. http://doi.org/10.1016/j.ejphar.2008.12.054

CONABIO. (1998). La diversidad biológica de México: Estudio de País. Comisión

CONABIO. (n.d.). Protected areas in Mexico. Retrieved March 20, 2020, from https://www.biodiversidad.gob.mx/v_ingles/region/areasprot/proctectedMexico.html

CONAFOR (2012). National Forest and Soil Inventory, report 2004-2009.

CONANP. (2013). Programa de Manejo Reserva de la Biosfera Tehuacán-Cuicatlán. Retrieved from https://www.conanp.gob.mx/que_hacemos/pdf/programas_manejo/tehuacan_2013.pd $\mathrm{f}$

CONANP. (2019, September 9). Reserva de la Biosfera Tehuacán - Cuicatlán. Retrieved from https:/www.gob.mx/conanp/documentos/reserva-de-la-biosferatehuacan-cuicatlan-209465

Conservación Biológica y Desarrollo Social, A. C. (CONBIODES, A. C.). (2017). Estudio de jaguar y especies asociadas en la Reserva de la Biosfera Tehuacán-Cuicatlán (CONANP/PROCODES/6807/2017). Retrieved from NA

Corbera, E., Estrada, M., May, P., Navarro, G., \& Pacheco, P.. (2011) "Rights to Land, Forests and Carbon in REDD+: Insights from Mexico, Brazil and Costa Rica." Forests 2.4: 301-42. Web.

Corradi, C., \& Bandelli, D. (2019). 10. Femicide. Handbook on Gender and Violence, 131.

Cronkleton, M. Cromberg, W.D. Sunderlin, A. Awono, and G. Selaya. \&quot;Gender Gaps in REDD+: Women's Participation Is Not Enough.\&quot; Center for International Forestry Research. Routledge, New York, USA, 09 May 2016. Web. 01 Mar. 2017.

Cusack, J.J., A. J. Dickman, J. M. Rowcliffe, C. Carbone, D. W. Macdonald, T. Coulson. (2015). Random versus Game Trail-Based Camera Trap Placement Strategy 
for Monitoring Terrestrial Mammal Communities. PLoS ONE 10(5): e0126373. https://doi.org/10.1371/journal.pone.0126373

Davis, T. J., et al. (2018). A distinctive new species of Thelocactus (Cactaceae) from Oaxaca, Mexico. Phytotaxa 361, Magnolia Press, Vol. 361, pp. 115-22.

de Gobierno, O. (1916). Grito de Dolores.

Dickman, A. J. (2010). Complexities of conflict: the importance of considering social factors for effectively resolving human-wildlife conflict. Animal conservation, 13(5), 458-466.

Distribution of soil types in Mexico. (2009, January 11). Retrieved from https://www.statista.com/statistics/249839/distribution-of-soil-units-in-mexico/

Duran, E., J. Robson, M. Briones-Salas, D. Bray, F. Berkes. (2012). Mexico: Wildlife eMammal. (n.d.). Study Design Recommendation for a Park | eMammal. Retrieved April 27, 2020, from https://emammal.si.edu/about/study-design/park

Enge, K.I. \& Whiteford, S. 1989. The keepers of water and earth: Mexican rural social organization and irrigation. University of Texas Press, Austin. 222 pp.

FAO, Food and Agriculture Organization of the United Nations. \&quot;FAO.org.\&quot; N.p., n.d.

Fernandez, R. (1943). Land Tenure in Mexico. Journal of Farm Economics, 25(1), 219234. Retrieved March 20, 2020, from www.jstor.org/stable/1231760

Fragoso, J. M. V., T. Levi, L. F. B. Oliveira, J. B. Luzar, H. Overman, J. M. Read, K. M. Silvius. (2016). Line transect surveys under detect terrestrial mammals: Implications for the sustainability of subsistence hunting. 11(4) 1-18.

García, E. (2004). Modificaciones al sistema de clasificación climática de Köppen. Universidad Nacional Autónoma de México.

García-Alaniz, N., M. Schmidt. (2016). Sistema nacional de monitoreo de la biodiversidad. Comisión Nacional para el Conocimiento y Uso de la Biodiversidad (CONABIO). 206 pp

Gelman, A., \& Hill, J. (2006). Data analysis using regression and multilevel/hierarchical models (1st ed.). New York, NY: Cambridge University Press. 
Gotelli, N. J., \& Colwell, R. K. (2001). Quantifying biodiversity: Procedures and pitfalls in the measurement and comparison of species richness. Ecology Letters, 4, 379-391.

Grigione, M. M., K. Menke, C. Lopez-Gonzalez, R. List, A. Banda, J. Carrera, R. Carrera, A. J. Giordano, J. Morrison, M. Sternberg, R. Thomas and B. Van Pelt. (2009). Identifying potential conservation areas for felids in the USA and Mexico: Integrating reliable knowledge across an international border. Oryx. 43.78 - 86. $10.1017 /$ S0030605308002019.

Harrison, K. \& Cantor, J. (1999). Tales from the screen: enduring fright reactions to scary media. Media Psychol. 1, 97- 116.

Harvey, N. (1998). The Chiapas rebellion: The struggle for land and democracy. Duke University Press.

Hatten, J. R., A. Averill-Murray, W. E. Van Pelt. (2002). Characterizing and mapping potential jaguar habitat in Arizona. Nongame and Endangered Wildlife Program Technical Report 203. Arizona Game and Fish Department, Phoenix, Arizona.

Hatten, J. R., A. Averill-Murray, W. E. Van Pelt. (2005). A spatial model of potential jaguar habitat in Arizona. The Journal of Wildlife Management, Vol. 69, pp. 10241033 Stable URL: http://www.jstor.org/stable/3803341

Hazzah, L.N. (2006). Living among lions (Panthera leo): coexistence or killing? Community attitudes towards conservation initiatives and the motivations behind lion killing in Kenyan Maasailand. Madison: University of Wisconsin-Madison.

Hernández Juárez , L. E., \& Morales Cantu, C. (2014, December 1). Diagnostico situacional sobre la posición y condición de género en el Municipio de Caltepec, Puebla. Retrieved April 26, 2020, from http://cedoc.inmujeres.gob.mx/documentos_download/CDI/CDI_Caltepec_Pue_2014. pdf

History.com Editors. (2018, August 21). Mexico Timeline. Retrieved from https://www.history.com/topics/mexico/mexico-timeline

History.com Editors. (2020, February 21). Aztecs. Retrieved from https://www.history.com/topics/ancient-americas/aztecs

Howe, E. J., Buckland, S. T., Després-Einspenner, M.-L., Kühl, H. S., \& Matthiopoulos, J. (2017). Distance sampling with camera traps. Methods in Ecology and Evolution, 8, 1558-1565. http://doi.org/10.1016/j.ejphar.2008.12.054 
INAFED. (n.d.). Principales Datos Socioeconmicos por Municipio. Retrieved April 26, 2020, from

http://www.inafed.gob.mx/es/inafed/Principales_Datos_Socioeconomicos_por_Muni cipio

INEGI. 1981. Carta Topográfica, 1:250,000. Oaxaca, E 14-9. Instituto Nacional de Estadística, Geografía e Informática (INEGI). México

Iowa Department of Natural Resources. (2003). Mammal monitoring for small, medium, and large mammals. multiple species inventory and monitoring manual, 113. Retrieved from http://www.iowadnr.gov/Environment/WildlifeStewardship/NonGameWildlife/Diver sityProjects/MSIM/MSIMManual.aspx

Jansen, P. A., T. D. Forrester, W. J. Mcshea. (2014). Protocol for camera-trap surveys of mammals at CTFS-ForestGEO sites. Smithsonian Tropical Research Institute: Center for Tropical Forest Science (May), 1-15.

Johnson, N., N. Aréchiga-Ceballos, A. Aguilar-Setien. (2014). Vampire bat rabies: Ecology, epidemiology and control. Viruses 6, no. 5: 1911-1928.

Jones, A. (2000). Effects of cattle grazing on North American arid ecosystems: a quantitative review. Western North American Naturalist: Vol. 60 : No. 2 , Article 5. Available at: https://scholarsarchive.byu.edu/wnan/vol60/iss $2 / 5$

Karanth, K. U., \& Nichols, J. D. (1998). Estimation of tiger densities in India using photographic captures and recaptures. Ecology, 79(8), 2852-2862. https://doi.org/10.1890/0012-9658(1998)079[2852:EOTDII]2.0.CO;2.

Kays, R., S. Tilak, B. Kranstauber, P. A. Jansen, C. Carbone, M. Rowcliffe, T. Fountain, Z. He. (2011). Camera traps as sensor networks for monitoring animal communities. International Journal of Research and Reviews in Wireless Sensor Networks. 1 (2):19-29.

Kellert, S. R. (1993). The biological basis for human values of nature. The biophilia hypothesis, 42-69.

Koleff, P., T. Urquiza-Haas (coords.). (2011). Planeación para la conservación de la biodiversidad terrestre en México: retos en un país megadiverso. Comisión Nacional para el Conocimiento y Uso de la Biodiversidad-Comisión Nacional de Áreas Naturales Protegidas, México. Retrieved from: http://www.researchgate.net/publication/216838723_Priorizacin_de_reas_para_conse 
rvacin_de_la_herpetofauna_utilizando_diferentes_mtodos_de_seleccin/file/0cd361f7 $\mathrm{d} 45 \mathrm{dd} \overline{\mathrm{b}} 21 \overline{4} 93 \overline{\mathrm{e}} 481 \mathrm{cce} 9 \mathrm{fab} 2 . \mathrm{pdf}$

Larson, A.M., T. Dokken, A.E. Duchelle, S. Atmadja, I.A.P. Resosudarmo, P.

Lettieri, M. (2017). Violence Against Women in Mexico A report on recent trends in femicide in Baja California, Sinaloa and Veracruz. Retrieved from https://sites.sandiego.edu/tbi-femicide/files/2017/12/2016-2017-Femicide-ReportFinal.pdf

Lewis, P. M.; Simons, G. F.; Fennig, C. D., eds. (2013). Ethnologue: Languages of the World (16th edition). Dallas, TX (http://www.ethnologue.com): SIL International. ISBN 978-1556712166.

Libretexts. (2019). 10.1: Introduction, Simpson's Index and Shannon-Weiner Index. Retrieved April 27, 2020, from https://stats.libretexts.org/Bookshelves/Applied_Statistics/Book\%3A_Natural_Resour ces_Biometrics_(Kiernan)/10\%3A_Quantitative_Measures_of_Diversity\%2C_Site_S imilarity\%2C_and_Habitat_Suitability/10.01\%3A_Introduction $\% 2 \mathrm{C} \_$Simpson $\% \mathrm{E} 2$ $\% 80 \% 99$ s_Index_and_Shannon-Weiner_Index

Lichstein, J. W., Simons, T. R., Shriner, S. A., \& Franzreb, K. E. (2002). Spatial autocorrelation and autoregressive models in ecology. Ecological Monographs, 72(3), 445-463. https://doi.org/10.1890/0012-9615(2002)072[0445:SAAAMI]2.0.CO;2.

López-Ramos. E. 1981. Geología de México, Tomo III. Publ. Particular autorizada, México, D.F. 446 pp.

MacKenzie, D. I., \& Nichols, J. D. (2004). Occupancy as a surrogate for abundance estimation. Animal Biodiversity and Conservation, 27(1), 461-467.

MacKenzie, D. I., \& Royle, J. A. (2005). Designing occupancy studies: General advice and allocating survey effort. Journal of Applied Ecology, 42(6), 1105-1114. https://doi.org/10.1111/j.1365-2664.2005.01098.x.

MacKenzie, D. I., Nichols, J. D., Hines, J. E., Knutson, M. G., \& Franklin, A. B. (2003). Estimating site occupancy, colonization, and local extinction when a species is detected imperfectly. Ecology, 84(8), 2200-2207. https://doi.org/10.1890/02-3090.

MacKenzie, D. I., Nichols, J. D., Lachman, G. B., Droege, S., Royle, J. A., \& Langtimm, C. A. (2002). Estimating site occupancy rates when detection probabilities 
are less than one. Ecology, 83(8), 2248-2255. https://doi.org/10.1890/00129658(2002)083[2248:ESORWD]2.0.CO;2.

Maffei, L., A. J. Noss, E. Cuéllar, and D. I. Rumiz. 2005. Ocelot (Felis pardalis) population densities, activity, and ranging behaviour in the dry forests of eastern Bolivia: data from camera trapping. J. Trop. Ecol. 21, 349-353.

Mangelsdorf, P. C., MacNeish, R. S., Galinat, W. C. (1964) "Domestication of Corn." Science, vol. 143, no. 3612, p. 1310 LP-1310, doi:10.1126/science.143.3612.1310.

Marker, L. (2002). Aspects of cheetah (Acinonyx jubatus) biology, ecology and conservation strategies on Namibian farmlands. Oxford: University of Oxford.

Martin, E. H., Ndibalema, V. G., \& Rovero, F. (2017). Does variation between dry and wet seasons affect tropical forest mammals' occupancy and detectability by camera traps? Case study from the Udzungwa Mountains, Tanzania. African Journal of Ecology, 55(1), 37-46. https://doi.org/10.1111/aje.12312.

Martorell, C. et al. (2017). A diversity world record in a grassland at Oaxaca, Mexico. Botanical Sciences, vol. 95, no. 1, 2017, p. 1., doi:10.17129/botsci.689.

Mexico - Country Profile. Convention on Biological Diversity. N.p., n.d. Web

Miaschi, J. (2019, August 12). Religious Beliefs In Mexico. Retrieved from https://www.worldatlas.com/articles/religious-beliefs-in-mexico.html

Millennium Ecosystem Assessment. (2005). Ecosystems and Human Well-being: Biodiversity Synthesis. World Resources Institute, Washington, DC.

Miller, R. S., M. L. Farnsworth, J. L. Malmberg. (2013). Diseases at the livestockwildlife interface: Status, challenges, and opportunities in the united states. Preventive Veterinary Medicine. 110:119-132. doi: 10.1016/j.prevetmed.2012.11.021

Miranda, F. (2019, March 7). Only 26\% of communal landowners in Mexico are women. Retrieved from https://www.eluniversal.com.mx/english/only-26-communallandowners-mexico-are-women

Muñoz, V., Monserrat, M. A., Martínez Méndez, R., Muñoz, V., \& Serafín, J. G. (2013). CARACTERIZACIÓN DE LOS TRABAJADORES DE LAS EMPRESAS MAQUILADORA LOCALIZADAS EN TEHUACÁN PUEBLA, MÉXICO (Characterization of Assembly Plants Workers Located at Tehuacan at the State of Puebla, Mexico). Revista International Administración \& Finanzas, 6(5), 95-107. 
Nacional Para El Conocimiento Y Uso de La Biodiversidad, 605(1-3), 129-37.

National Water Commission (CONAGUA). (2015). Statistics on Water in Mexico, 2015 Edition (2015 Edition). Retrieved from http://www.conagua.gob.mx/CONAGUA07/Publicaciones/Publicaciones/EAM2015 ing.pdf

Naughton-Treves, L., Grossberg, R., \& Treves, A. (2003). Paying for tolerance: rural citizens' attitudes toward wolf depredation and compensation. Conservation biology, 17(6), 1500-1511.

Nichols, J. D., Bailey, L. L., Talancy, N. W., Grant, E. H. C., Gilbert, A. T., Annand, E. M., ... Hines, J. E. (2008). Multi-scale occupancy estimation and modelling using multiple detection methods. Journal of Applied Ecology, 45(5), 1321-1329. https://doi.org/10.1111/j.1365-2664.2008.01509.x.

O'Brien, T. G., Kinnaird, M. F., \& Wibisono, H. T. (2003). Crouching tigers, hidden prey: Sumatran tiger and prey populations in a tropical forest landscape. Animal Conservation, 6(2), 131-139. https://doi.org/10.1017/S1367943003003172.

Oksanen, J. (2013). Vegan: ecological diversity. R Project.

O'reilly, K. (2012). Ethnographic methods. Routledge.

Ostrom, E. (2002). Common-pool resources and institutions: Toward a revised theory. Handbook of agricultural economics, 2, 1315-1339.

Palmer, M. S., Swanson, A., Kosmala, M., Arnold, T., \& Packer, C. (2018).

Evaluating relative abundance indices for terrestrial herbivores from large-scale camera trap surveys. African journal of ecology, 56(4), 791-803.

Parkes, H. B., Bernstein, M. D., Palerm, A., Meyer, M. C., Griffin, E. C., \& Willey, G. R. (2020). Mexico. In Encyclopedia Britanica. Retrieved from https://www.britannica.com/place/Mexico

Parks Watch. (2002). Mexico: Tehuacán-Cuicatlán Biosphere Reserve. Retrieved from http://www.parkswatch.org/parkprofiles/pdf/tcbr_eng.pdf

Pimentel, D., Zuniga, R. \& Morrison, D. (2005). Update on the environmental and economic costs associated with alien-invasive species in the United States. Ecol. Econ. 52, 273- 288. 
Prokop, P., Fancovicova, J. \& Kubiatko, M. (2009). Vampires are still alive: Slovakian students' attitudes toward bats. Anthrozoos 22, 19- 30.

Rényi, A. (1961). On Measures of Entropy and Information. Proc. Fourth Berkeley Symp. Math. Stat. Prob., 1, 547-561

Ridout, M. S., \& Linkie, M. (2009). Estimating overlap of daily activity patterns from camera trap data. Journal of Agricultural, Biological, and Environmental Statistics, 14(3), 322-337. https://doi.org/10.1198/jabes.2009.08038.

Robinson, M. J., C. Bradley, J. Boyd. (2005). Suitable habitat for jaguar in New Mexico. Center for Biological Diversity. Tucson, Ar.

Robles De Benito, R. (2009). Las unidades de manejo para la conservación de vida silvestre y el Corredor Biológico Mesoamericano México. Comisión Nacional para el Conocimiento y Uso de la Biodiversidad (CONABIO). México. 134 pp.

Røskaft, E., Bjerkec, T., Kaltenborn, B., Linnell, J.D.C. \& Anderson, R. (2003).

Patterns of self-reported fear towards large carnivores among the Norwegian public.

Evol. Human Behav. 24, 184- 198.

Rota, C. T., Ferreira, M. A. R., Kays, R. W., Forrester, T. D., Kalies, E. L., McShea, W. J., ... Millspaugh, J. J. (2016). A multispecies occupancy model for two or more interacting species. Methods in Ecology and Evolution, 7(10), 1164-1173. https://doi.org/10.1111/2041-210X.12587.

Rowcliffe, J. M., Field, J., Turvey, S. T., \& Carbone, C. (2008). Estimating animal density using camera traps without the need for individual recognition. Journal of Applied Ecology, 45(4), 1228-1236. https://doi.org/10.1111/j.13652664.2008.01473.x.

Royle, J. A., Nichols, J. D., Karanth, K. U., \& Gopalaswamy, A. M. (2009). A hierarchical model for estimating density in camera-trap studies. Journal of Applied Ecology, 46(1), 118-127. https://doi.org/10.1111/j.1365-2664.2008.01578.x.

Sánchez-Cordero, V., F. Botello, J. J. Flores-Martínez, R. A. Gómez-Rodríguez, L. Guevara, G. Gutiérrez-Granados, Á. Rodríguez-Moreno. (2014). Biodiversidad de Chordata (Mammalia) en México. Revista Mexicana de Biodiversidad, 85(SUPPL.). http://doi.org/10.7550/rmb.31688

Schieltz, J.M, D. I. Rubenstein. (2014). Evidence based review: positive versus negative effects of livestock grazing on wildlife. What do we really know? Environ. Res. Lett. 11113003 
SEMARNAT (n.d) Web site. Retrieved March 20. 2020 from http://www.semarnat.gob.mx./web_ingles .

Sillero-Zubiri, C. \& Laurenson, M.K. (2001). Interactions between carnivores and local communities: conflict or co-existence? In Carnivore conservation: 282-312. J.L. Gittleman, S.M. Funk, D.W. Macdonald \& R.K. Wayne (Eds). Cambridge: Cambridge University Press.

Silveira, L., Jacomo, A. T., \& Diniz-Filho, J. A. F. (2003). Camera trap, line transect census and track surveys: a comparative evaluation. Biological conservation, 114(3), 351-355.

Sistema de Información Económica (SIE, Banco de México). (n.d.). Ingresos por remesas, distribución por municipio. Retrieved April 26, 2020, from https://www.banxico.org.mx/SieInternet/consultarDirectorioInternetAction.do?sector $=1 \&$ accion $=$ consultarCuadro\&idCuadro $=\mathrm{CE} 166 \&$ locale $=\mathrm{es}$

Sjoberg, L., Moen, B.-E. \& Rundmo, T. (2004). Explaining risk perception: an evaluation of the psychometric paradigm in risk perception research. Rotunde $84,1-$ 39.

Skogen, K., Mauz, I. \& Krange, O. (2008). Cry wolf!: narratives of wolf recovery in France and Norway. Rural Sociol. 73, 105- 123.

Smith, B. D. (2005) "Reassessing Coxcatlan Cave and the Early History of Domesticated Plants in Mesoamerica." Proceedings of the National Academy of Sciences of the United States of America, vol. 102, no. 27, July 2005, p. 9438 LP-9445, doi:10.1073/pnas.0502847102.

Sollmann, R. (2018). A gentle introduction to camera-trap data analysis. African journal of ecology, 56(4), 740-749.

Sollmann, R., Mohamed, A., Samejima, H., \& Wilting, A. (2013). Risky business or simple solution-Relative abundance indices from camera-trapping. Biological Conservation, 159, 405-412. https://doi.org/10.1016/j.biocon.2012.12.025.

Starr, C. (1969). Social benefits vs. technological risks. Science 165, 1232- 1238.

teleSUR /ef-ML (2019, March 3). Land Rights Still Elusive For Women In Mexico. Retrieved from https://www.telesurenglish.net/news/Land-Rights-Still-Ellusive-ForWomen-In-Mexico--20190303-0009.html 
The Diverse Islands of Mexico. (2019, January 29). Retrieved from https://online.seterra.com/en/p/mexico-islands

Thirgood, S., Woodroffe, R. \& Rabinowitz, A. (2005). The impact of human-wildlife conflict on human lives and livelihoods. In People and wildlife: conflict or coexistence?: 13-26. R. Woodroffe, S. Thirgood \& A. Rabinowitz (Eds). Cambridge: Cambridge University Press.

Thomson, G. (2018). Benito Juárez and Liberalism. In Oxford Research Encyclopedia of Latin American History.

Ugland, K. I., Gray, J. S., \& Ellingsen, K. E. (2003). The species-accumulation curve and estimation of species richness. Journal of Animal Ecology, 72(5), 888-897.

UNESCO World Heritage Centre. (n.d.). Tehuacán-Cuicatlán Valley: originary habitat of Mesoamerica. Retrieved March 20, 2020, from https://whc.unesco.org/en/list/1534/

Villanueva Ulfgard, R., \& Villanueva, C. (2020). The power to transform? Mexico's 'Fourth Transformation'under President Andrés Manuel López Obrador. Globalizations, 1-16.

Villegas, P. (2020, February 26). Women in Mexico Are Urged to Disappear for a Day in Protest. Retrieved from https://www.nytimes.com/2020/02/26/world/americas/mexico-un-dia-sinnosotras.html

Williams, B. K., Nichols, J. D., \& Conroy, M. J. (2002). Analysis and management of animal populations: Modeling, estimation, and decision making. San Diego, CA and London, UK: Academic Press.

Wolf, E. R. (1958). The Virgin of Guadalupe: a Mexican national symbol. The Journal of American Folklore, 71(279), 34-39.

Woodroffe, R., Thirgood, S., \& Rabinowitz, A. (Eds.). (2005). People and wildlife, conflict or co-existence? (No. 9). Cambridge University Press.

World Resources Institute. (n.d.) Global Forest Watch. N.p., Web. 
compliance or complaints regarding this study must be reported to this office in a timely manner. Please use the INSTRUCTIONS and FORM: Unanticipated Problem / Serious Adverse Event Form found both on our web site and the IRBNet Library.

If you have any questions or need guidance on CITI training, please contact MTU-IRB office at 906-487-2902 or send an e-mail message to irb@mtu.edu. 


\section{A.2 2019 Interview Questionnaire}

\section{A.2.1 English Version}

Survey Num.

General Survey on Livestock and Wild Animals in the Tehuacán-Cuicatlán Biosphere Reserve

Introduction:

The purpose of this survey is to collect information on livestock practices in the Tehuacán-Cuicatlán Biosphere Reserve (RBTC) and relate them to the presence, distribution and interaction with wildlife. This survey is anonymous and confidential. The information collected will be used for a thesis of the MTU and a study of the RBTC to improve the knowledge on this subject. You have the right not to respond or participate in the survey, and the right to refuse to answer specific questions of the survey if you choose to participate. The survey will take 20 minutes of your time and we can help with any questions you may have. We appreciate your time and your answers. Thank you!

Demographic information:

Community Name:

Communal land management:

What is your age?

Less than 18 years old 35 to 44

18 to 24

45 to 54

25 to 34

$55+$

What gender do you identify as?

Masculine

Feminine

Prefer not to answer 
What is your education level?
Some education
College degree
High school
Other

What is your marital status?
Single
Married
Divorced
Other

What is your profession?

\section{Information about community livestock practices}

How many domestic animals in your village are on communal land (estimated)? Indicate how many of the following animals:
Horses
Mules
Cows
Donkeys
Goats
Sheep

How many times and in what months do you change where the animals are grazed?

How many times a year do the animals get vaccinated and in what months- does everyone vaccinate their animals? How expensive are the vaccinations?

Have some of the livestock died this year? How many?

Horses
D Donkeys

Mules

Cows

How did they die? 
How much do the following animals cost on average when fully grown?

$\begin{array}{lll}\text { Horses } & \text { Mules } & \text { Cows } \\ \text { Donkeys } & \text { Goats }\end{array}$

Are there feral dogs in the area? Are they a problem?

Is there a species of animal that is dangerous in the area?

Is there a native species in the RBTC that is of great value?

If someone loses a domestic animal in the community by a wild animal, what actions are taken?

From 1-5, after the implementation of biodiversity monitoring programs in the community have you seen changes in how the community reacts to wildlife?

Nothing Not much $\quad$ More or less $\quad$ Yes $\quad$ Yes, a lot

$\begin{array}{lllll}1 & 2 & 3 & 4 & 5\end{array}$

\section{Personal livestock practices:}

Do you have domestic animals? Indicate how many of the following.

Horses

Donkeys
Mules

Goats
Cats

Dogs 


$\begin{array}{ll}\text { Chickens } & \text { Cows } \\ \text { Turkeys } & \text { Sheep } \\ \text { Ducks } & \ldots \text { Other }\end{array}$

Indicate how many of your domestic animals you have on communal land:

Horses

Mules

Cows

Donkeys

Goats

Sheep

Have you had livestock losses? How? What did you do?

Who should be responsible for livestock losses caused by wildlife?

What programs would you like to see offered in relation to livestock losses?

Have you participated in community biological monitoring?

From 1-5 how important is biodiversity monitoring?

$\begin{array}{crrrr}\text { Not important } & \text { Not very } & \text { More or less } & \text { Important } & \text { Very important } \\ 1 & 2 & 3 & 4 & 5\end{array}$

With the biological monitoring program, have you changed the way you think and act towards native biodiversity?

\section{A.2.2 Spanish Version}

Encuesta No.

Encuesta General Sobre Ganado y Animales Silvestres en la Reserva de la Biosfera Tehuacán-Cuicatlán 
Introducción:

La propuesta de esta encuesta es definir las prácticas de ganadería en la Reserva de la Biosfera Tehuacán-Cuicatlán (RBTC) y relacionarlas con la presencia, distribución y interacción con la vida silvestre. Esta encuesta es anónima y confidencial - no pedimos nombres o información muy personal. La información que colectamos estaría utilizada para una tesis de Michigan Technological University y un estudio de la RBTC para mejorar el conocimiento de este subjeto. Usted tiene el derecho a no responder o participar en la encuesta. La Encuesta tomará 20 minutos de su tiempo y podemos ayudar con cualquier duda que tenga. Nos agradecemos de su tiempo y sus respuestas - nos ayuda a mejorar los programas y apoyo para usted... ¡Muchas Gracias!

Información demográfica:

Nombre de Comunidad:

Núcleo Agrario:

¿Cuál es su edad? (rango amplio)

Menor a 18

18 años a 24 años

25 años a 34 años

35 años a 44 años

45 años a 54 años

Mas de 54

¿Con qué género le identifica más?

Masculino

Femenino

Preferiría no contestar

¿Cuál es su nivel escolar?

Preparatoria

Licenciatura (o posgrado)

¿Cuál es tu estado civil?
No terminó la escuela

Otro 

Soltero
Casado
Divorciado
Viudo/Otro

¿En qué trabajo/labor se dedica usted?

Información de la ganadería del pueblo

¿Cuántos animales domésticos en su pueblo están en tierra comunal (estimado)? Indica cuantos de los siguientes animales:

$-$

_ Caballos

Mulas
Chivos

Reses/Vacas

Burros

Borregos

¿Cuántos veces al año se cambian los animales de lugar? ¿Cuándo (cuales meses)?

¿Cuántos veces al año se vacunan los animales domésticos? ¿En cuál mes(es)? ¿Cuánto cuesta?

¿Han tenido pérdidas de los animales domésticos? ¿Cuántos en el año?

Caballos

Mulas

Reses/Vacas

Burros

Chivos

Borregos

¿Cómo murieron?

¿Por cuántos pesos se puede vender uno de los siguientes animales ya listos para comer?
_ Caballos
Mulas
Reses/Vacas
Burros
Chivos
Borregos

¿Hay perros o animales ferales en la zona? ¿Generan problemas? 
¿Hay una especie de animal o grupo que considere riesgoso o problemático en la zona?

¿Hay una especie de animal nativa que mas se valora adentro de la RBTC?

¿Si tienen una pérdida de uno de sus animales por un animal silvestre (puma/coyote/murciélago), que acciones se toman la gente de la comunidad?

¿De 1-5, después de programas como monitoreo de la biodiversidad ha visto un cambio en la comunidad con respeto a la vida silvestre?

$\begin{array}{ccccc}\text { Nada } & \text { No mucho } & \text { Mas o menos } & \mathrm{Si} & \text { Si mucho } \\ 1 & 2 & 3 & 4 & 5\end{array}$

\section{Información sobre las prácticas personales de la ganadería:}

¿Usted tiene animales domésticos? Indica cuántos de cada animal domestica.

_ Caballos

_ Burros

_ Mulas

Chivos
Gatos

Perros

Pollos/Gallinas

Pavos
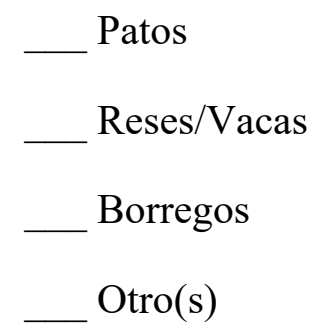

¿Cuáles animales tiene usted en una zona comunal? Indica cuantos animales.

Caballos

Burros

Mulas
Chivos

Reses/Vacas

Borregos

¿Ha tenido pérdidas de sus animales? ¿Qué paso y cuándo? ¿Qué hizo usted? 
¿Quién debería estar responsable de pérdidas de animales domesticas por animales silvestres?

¿Qué programas le gustaría ver aplicado con relación a perdidas de ganado?

¿Ha participado en monitoreo de la biodiversidad?

¿De $1-5$, que tan importante es el programa de monitoreo de la biodiversidad?

No importante No mucho Mas o menos Importante Muy importante 1 2 3

4 5

¿Con el programa ha visto cambios en la manera que piensa sobre la vida silvestre? ¿Ha tomado acciones diferentes en relación con los animales silvestres? 


\section{B Appendix B}

\section{B.1 $\quad \mathbf{R}$ script used in camera trap analysis}

\section{B.1.1 Shannon Wiener and Rényi Code}

shanwin <- read.csv ("D:/shanwin.csv", row.names=1)

$>\quad$ view(shanwin)

$>$ data<-data.frame (shanwin)

$>$ diversity (shanwin, index="shannon")

Agua de Guayabito

1.5474049

Agua del Higo

1.3120761

Agua Salada

2.1433997

Barranca de Puerto Suelo

E1 Rincon

0.6730117

La Palmonera

1.5692804

Pochote

1.7531775

Puerto Suelo Pichilingue

1.7298201

Tepayo

Agua del Carrizo

1.8006054

Agua El Hujzache

1.4748652

Barranca Chicozapote

1.2670742

E1 Corra1

1.2964484

Joya de1 Zotole

2.0796863

Paraje Salvido

1.5099678

Pochote 2

1.2784216

Rincon Danero

1.1988182

Tepayo 2

$>$ Shannon<-diversity (shanwin, index = "shannon")

$>\operatorname{plot}($ Shannon)

$>\mathrm{k}<-$ sample(nrow(shanwin), 6)

$>\mathrm{R}<-\operatorname{renyi}($ shanwin $[\mathrm{k}$,$] )$

$>\operatorname{plot}(R)$

\section{B.1.2 Species Accumulation Curve}

detections_heatmap_plot <-

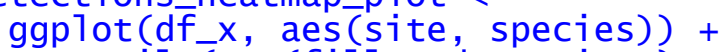
geom_tile(aes (fi11 = detections), colour = "white") + scale_fi11_gradient(1ow = "white", high = "b1ack") + labs ( $\bar{x}=$ "site number", $y=$ "species number") + ggtitle("Detections of' species at sites over " $X$ " visits");

plot(detections_heatmap_plot)

\section{B.1.3 Correlation code}

$\operatorname{cov}(x, y=$ NULL, use = "everything",
method = c("pearson", "kenda11", "spearman"))

pab <- read.csv("D:/pab.Csv", row.names=1)

$>\quad$ view(pab)

$>$ cor.test (pab\$coati, pab\$Donkey)

\section{B.1.4 Chi-squared Code}

chisq. test $(x, y=N U L L$, correct $=$ TRUE,

$$
\begin{aligned}
& \mathrm{p}=\operatorname{rep}(1 / 1 \text { ength }(\mathrm{x}), \operatorname{length}(\mathrm{x})) \text {, rescale. } \mathrm{p}=\text { FALSE, } \\
& \text { simulate. } \mathrm{p} \cdot \mathrm{value}=\text { FALSE, } \mathrm{B}=2000)
\end{aligned}
$$




\section{B.1.5 Scatter Plot of Pearson's Correlation}

$>$ cor.test (INWD\$spec, INWD\$in.)

\section{Pearson's product-moment correlation}

data: INWD\$spec and INWD\$in.

$\mathrm{t}=-11.984, \mathrm{df}=481, \mathrm{p}$-value $<2.2 \mathrm{e}-16$

alternative hypothesis: true correlation is not equal to 0

95 percent confidence interva1:

$-0.5453998-0.4077340$

sample estimates:

$$
\text { cor }
$$

$-0.4795118$

$>$ ggscatter (INWD, $x=$ "spec", $y=$ "in.", add = "reg.7ine", conf.int $=T$ RUE, cor. coef = TRUE, cor. method = "pearson", $x 1 a b=$ "species", ylab = "Type of interaction")

\section{B.1.6 Kernel Density Estimation}

\#\#\# file to read time data 04/06/2020

require(lubridate)

time $=$ read. $\operatorname{csv}\left(\right.$ ' $D: /$ time. $C S V^{\prime}$, header $\left.=T\right)$

datez = as.POSIXct (time\$Hour, format $=$ ' $\%$ H:\%M:\%S')

hourz = hour (datez)

\#\#\# Make a density distribution

plot (density (hourz[1:637]), bty="n", $x 1 \mathrm{im}=c(0,25), y 1 \mathrm{im}=c(0,0.1), 1 \mathrm{wd}=$ 2 , $x 1 \mathrm{ab}=$ "Hours (24 hr)", main = "Densities of wildiife Activity")

\#\#\# add a color to the plot

polygon(density (hourz[1:637]), col = "1ight blue")

\#\#\# add a line to the plot

abline ( $v=$ mean (hourz $[1: 631]), 1 t y=3$ )

\#\#\# add a linte to the plot

abline $(v=$ median (hourz $[1: 631])$ )

\section{B.2 R script used in ethnographic analysis}

\section{B.2.1 Simple bar graph}

\# Define the animals vector with 2 values

$>$ animals <- c $(8,18)$

$>$ \# Graph animals with specified labels for axes. Use blue

$>$ barplot(animals, main="Animals on Common Land", xlab="Response",

+ ylab="Tota1", names. $\operatorname{arg=c}(" N o ", " Y e s ")$,

+ col= "7ight blue", border="b1ack")

$>$ \# Fitting Labels

$>\operatorname{par}(1 \mathrm{as}=1)$ \# make label text paralle1 to axis

$>$ barplot(rep\$Number. of.reports..n., names.arg = c("Prevention", "No AC tion", "Denial", "Mitigation", "Retaliation", "Unsure"), horiz = FALSE, $\mathrm{co1}=$ brewer.pa1 (1ength(6), "Paired"), $\mathrm{x} 1 \mathrm{ab}=$ "Response", $\mathrm{y} 1 \mathrm{ab}=$ "Number of Reports (n)", main = "Responses to wildlife Conflict in survey sampl $\mathrm{e}^{\prime}$, cex. names $=0.7$ )

\section{B.2.2 Box whisper plot}

$>$ Surveys.Exce1.Document <- read.csv("D:/MTU Thesis/Surveys Exce1 Docum ent. CSV", row. names $=1$ )

$>\quad$ View(Surveys. Exce1. Document) 


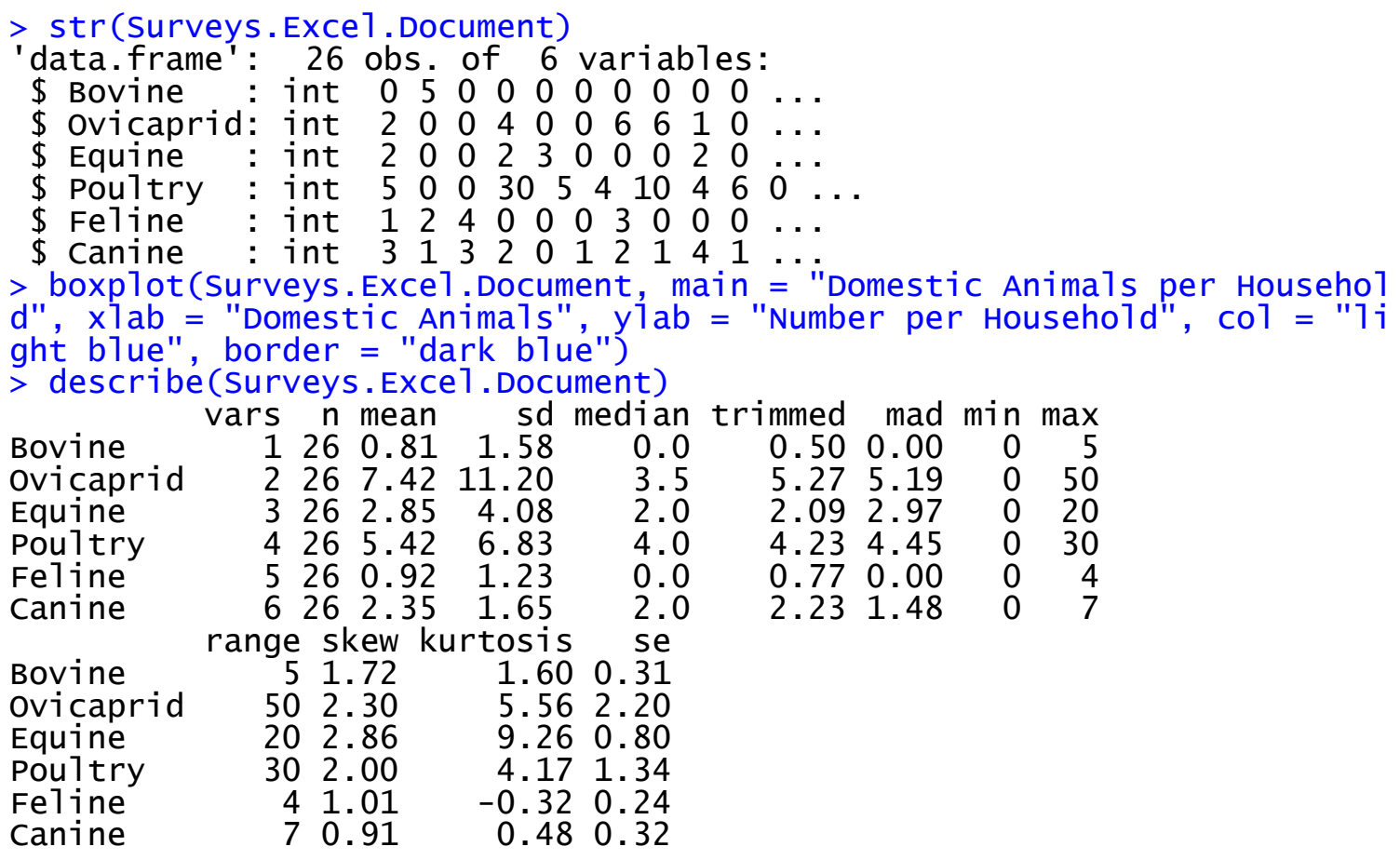

\section{B.2.3 Pie chart code}

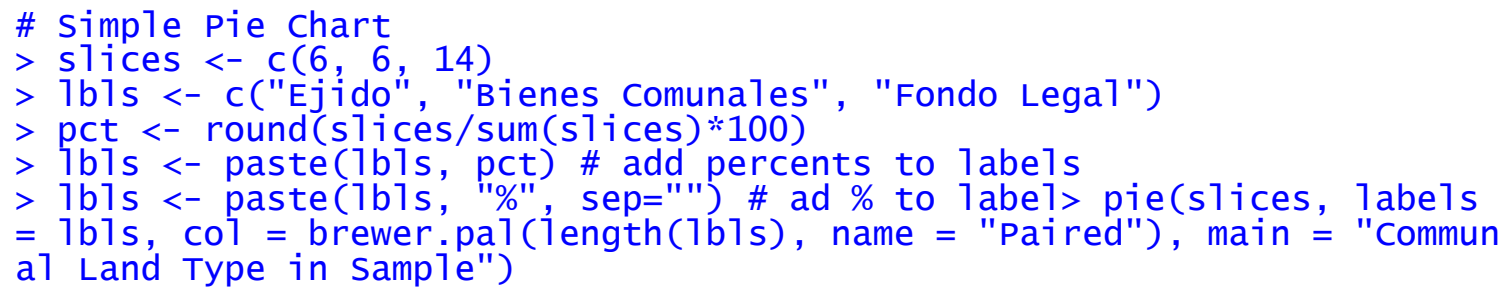




\section{Appendix C}

\section{C.1 Field Sheet for Biodiversity Monitoring}

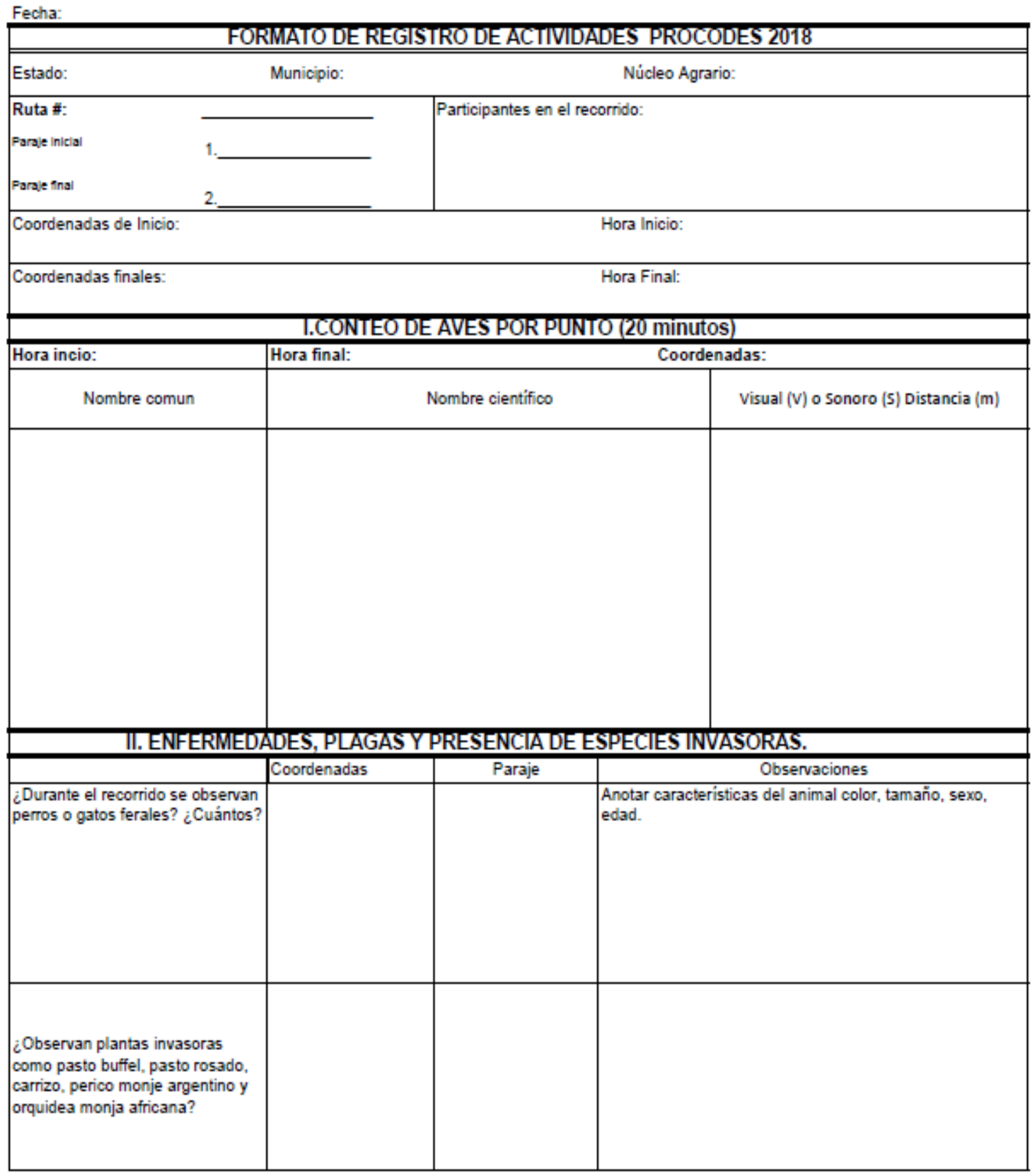




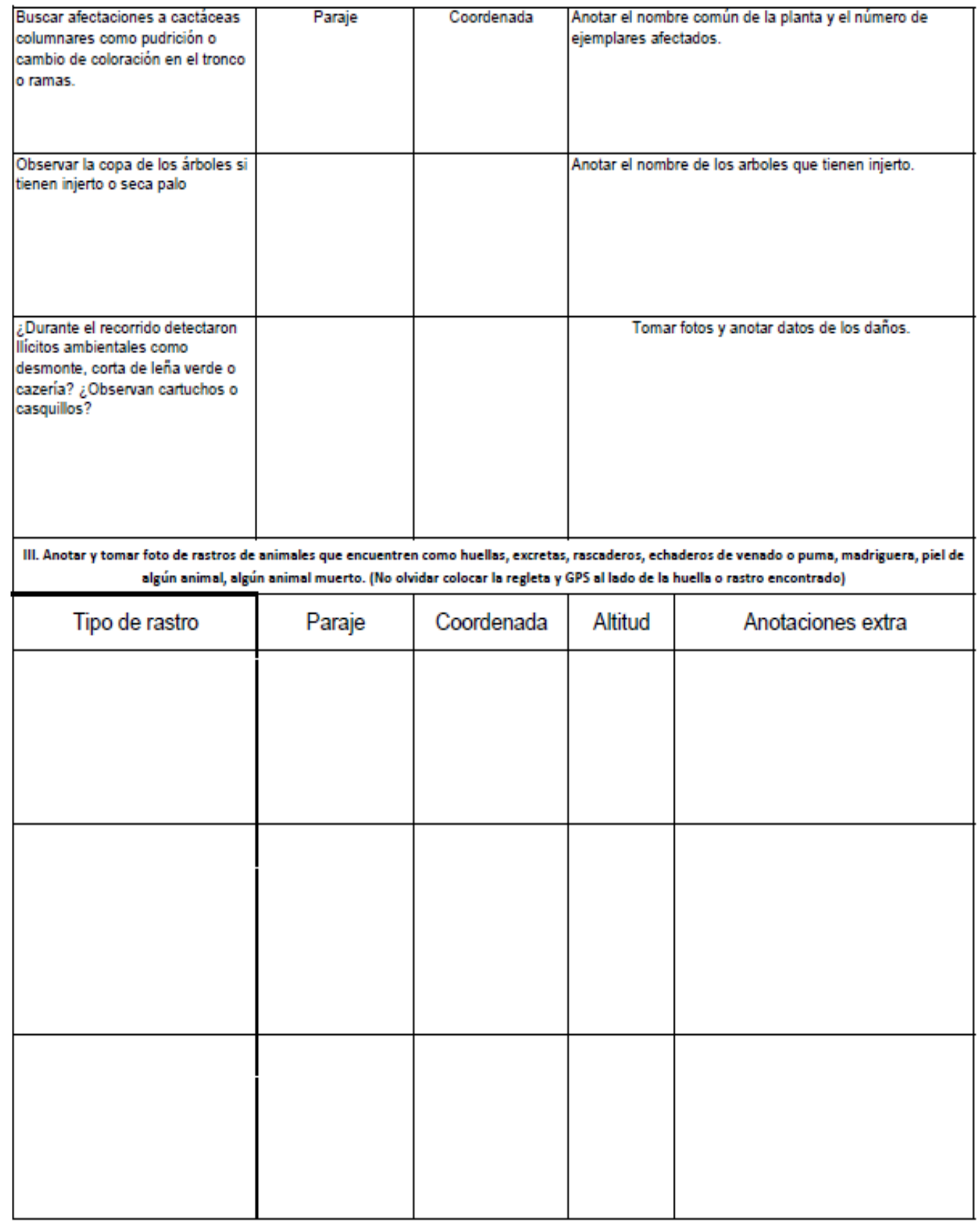




\section{El Mapa de Recorrido}

V. Anotar observaciones al recorrido ¿Cómo fue?; cansado, complicado, facíl ¿por qué?, además anotar que es lo que mas les gustó durante dicho recorrido.

NOTA: POR RECORRIDO ENTREGAR MINIMO 50 FOTOGRAFIAS; 25 DE PLANTAS (flores, árboles, arbustos, biznagas, magueyes, siemprevivas, soluches, orquideas, cactus, nopales, helechos, palma real, jarrilla. Plantas pequeñas y grandes.) Y 25 DE ANIMALES (alacranes, mariposas, caracoles, hormigas, escarabajos, moscas, azotadores, lagartijas, camaleon, arañas, aves, víboras, tortugas, rañas, zapos, abejas, abejorros, avispas, chapulines, grillos, chinches, cucarachas, insectos palo, campamochas, peces, tortuga de casquito y todo lo que encuentren en el camino). 


\section{C.2 Camera Trap Data Sheet}

Núcleo Agrario:

Fecha:

Hora:

Ubicación:

Elevación:

Nombre de Cámara:

Paraje:

Formato de la colocación de cámaras:

Orientación/Aspecto (Orientación norte, sur, oeste,

este): Pendiente:

Topografía (loma, valle, cerca, cuerpo de agua, roca):

Tipos de Vegetación Más Comunes:

1.

2.

3.

4.

5 (Opcional).

Signos (huellas y rastros): 


\section{Copyright documentation}

Most images in this document are from the Author's personal photo library. The listed figures are public domain or permissions have been acquired.

Figure 3.1: Figure of population age structure in Mexico (2018) (Central Intelligence Agency, 2020). Image within public domain. https://www.cia.gov/library/publications/the-world-factbook/geos/mx.html. Accessed March 19 ${ }^{\text {th }}, 2020$.

Figure 3.3: "Mexico's position in relation to tectonic plates. Map: Tony Burton / GeoMexico" accessed from: https://geo-mexico.com/?p=6277. Image used with the permission of Tony Burton.

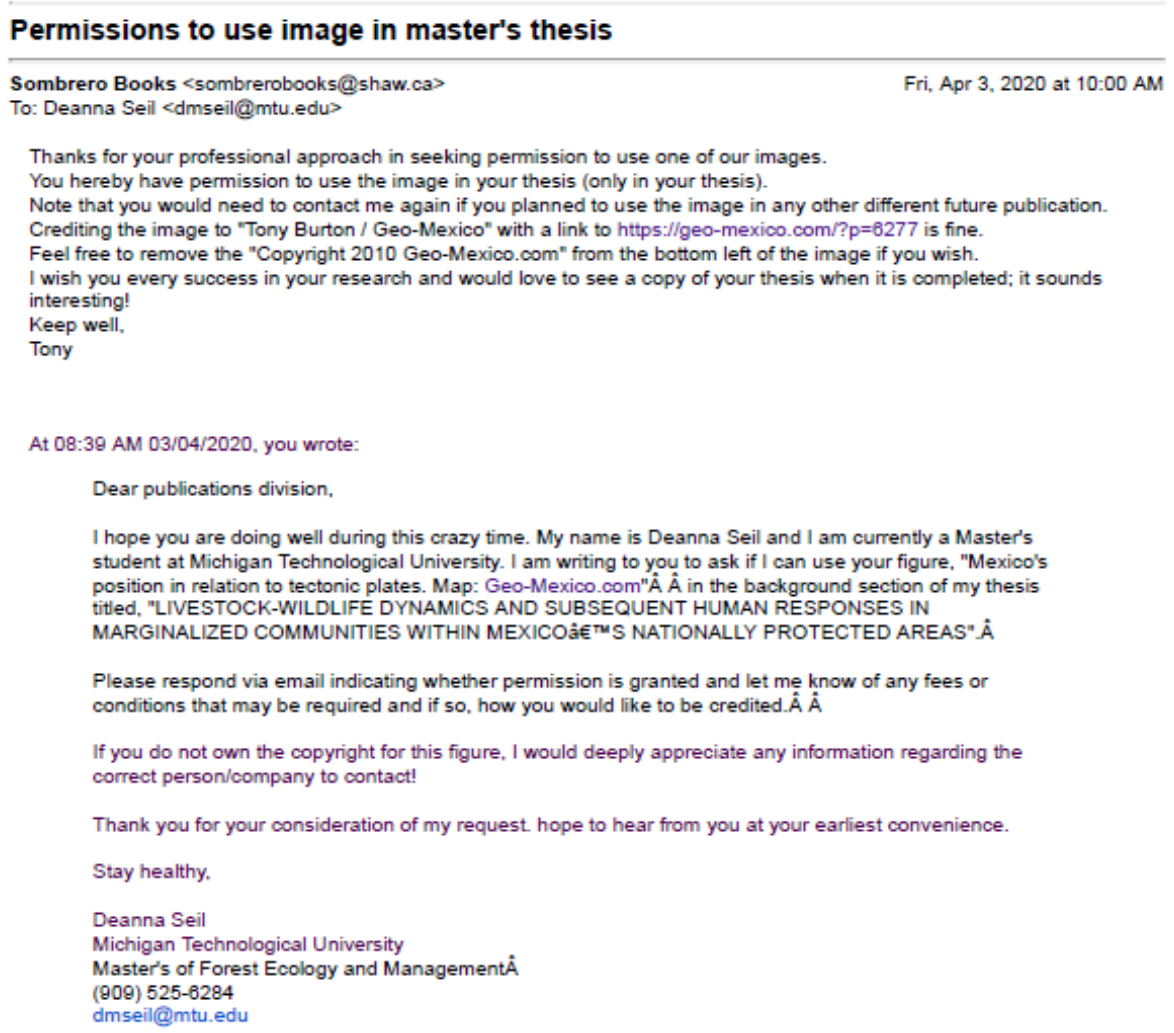

Figure 3.4: "Map of 11 physiographic regions of Mexico (Alcocer \& Bernal-Brooks, 2010)". Used with the permissions of Springer Nature. 


\title{
Thank you for your order with RightsLink / Springer Nature
}

no-reply@copyright.com <no-reply@copyright.com>

To: dmseil@mtu.edu

Fri, Apr 3, 2020 at 10:06 AM

\section{SPRINGER NATURE}

\author{
Thank you for your order! \\ Dear Ms. Deanna Seil, \\ Thank you for placing your order through Copyright Clearance Center's RightsLink ${ }^{2}$ \\ service.
}

$\begin{array}{ll}\text { Order Summary } & \\ \text { Licensee: } & \text { Deanna Seil } \\ \text { Order Date: } & \text { Apr } 3,2020 \\ \text { Order Number: } & 4801430187051 \\ \text { Publication: } & \text { Hydrobiologia } \\ \text { Title: } & \text { Limnology in Mexico } \\ \text { Type of Use: } & \text { Thesis/Dissertation } \\ \text { Order Total: } & 0.00 \text { USD }\end{array}$

View or print complete details of your order and the publisher's terms and conditions.

Sincerely.

Copyright Clearance Center

Tel: $+1-855-239-3415 /+1-978-646-2777$

customercare@copyright.com

https://myaccount.copyright.com

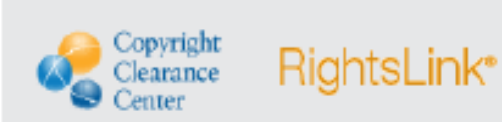

